\title{
VolPFix: Uma ferramenta para análise e detecção de falhas em sistemas de telefonia IP
}

\author{
Paulo César Siécola
}

\section{DISSERTAÇÃO APRESENTADA}

AO INSTITUTO DE MATEMÁTICA E ESTATÍSTICA DA

UNIVERSIDADE DE SÃO PAULO

PARA

OBTENÇÃO DO TÍTULO

DE

MESTRE EM CIÊNCIAS

Programa: Ciência da Computação

Orientador: Prof. Dr. Fabio Kon 



\section{VolPFix: Uma ferramenta para análise e detecção de falhas em sistemas de telefonia IP}

Esta versão definitiva da dissertação contém as correções e alterações sugeridas pela Comissão Julgadora durante a defesa realizada por Paulo César Siécola em 10/02/2011.

Comissão julgadora:

- Prof. Dr. Fabio Kon (orientador) - IME-USP

- Prof. Dr. Daniel Macedo Batista - UNICAMP

- Prof. Dr. Edson dos Santos Moreira - ICMC-USP

- Prof. Dr. Wagner Luiz Zucchi - EP-USP 


\section{Agradecimentos}

Deus, somente Tu sabes de minha jornada, das minhas limitações, dos desafios e obstáculos que superei. Sabes também que sem a Tua mão poderosa nada seria possível. Diante de Ti, só posso louvar Teu Santo nome e agradecer por estar sempre ao meu lado.

Rogério e Joana, meus amados pais. Nem mil palavras seriam suficientes para agradecê-los. Vocês me criaram com dedicação, amor e carinho. Nem sei quantos sacrifícios fizeram por minha causa, para que eu pudesse chegar até aqui, mas tenho certeza de que foram muitos. Por várias vezes, mesmo sem saber, vocês me educaram como verdadeiros mestres da vida. Obrigado pelo apoio, pelo amor e pela dedicação.

Isabel, minha amada imortal. Você esteve do meu lado desde o primeiro momento dessa minha jornada, me apoiando e me incentivando. Você transformou minha vida, minha mente e meu coração. Eu sou abençoado por ter uma mulher incrível ao meu lado como minha esposa. Agradeço pelo companheirismo nas manhãs, tardes, noites e feriados de estudo. Agradeço-te por tudo.

Agradeço ao professor Dr. Fabio Kon, pela dedicação e pelos sábios conselhos que ajudaram a concretizar este trabalho e a torná-lo melhor.

Aos professores de minha banca, agradeço pelos conselhos e pela contribuição.

Agradeço à Daniela Santos, pela ajuda nas correções e melhorias do texto.

Aos meus amigos do IME; Charles lury, Giseli Ramos, Rogério Rondini, Roger Ricardo, Lucas Ruiz e tantos outros, agradeço pelo companheirismo e pela inestimável amizade.

Finalmente, agradeço à empresa em que trabalho, a Leucotron Telecom, em especial meu Gerente, Ricardo Varejão, pelo apoio, confiança e incentivo. 


\section{Resumo}

Com os avanços das tecnologias de transmissão de dados e com a popularização dos acessos à Internet por meio de banda larga para empresas e usuários domésticos, a telefonia IP tornou-se uma tecnologia de uso generalizado.

As prestadoras de serviço de telefonia IP, também chamadas de operadoras VolP, apareceram para conquistar esse mercado crescente. Essas empresas oferecem planos com tarifas mais reduzidas, principalmente para ligações a longa distância e internacionais, uma vez que sua grande vantagem está no fato de utilizar infraestrutura existente de rede utilizada para transporte de dados, como a Internet.

Apesar dos benefícios que a tecnologia VolP trouxe, muitos problemas são enfrentados pelos usuários, pois o sistema de telefonia IP depende fortemente de recursos que não estão sob o controle das aplicações e equipamentos responsáveis por oferecer esse serviço.

O projeto VolPFix, apresentado nesta dissertação, surgiu da necessidade de uma ferramenta que complementasse as demais existentes no ramo de análise de redes de computadores e telefonia IP. Muitos dos profissionais que trabalham nesse mercado possuem um conhecimento limitado das tecnologias e protocolos dos equipamentos de VolP, pois é algo muito específico desse tipo de tecnologia.

O VolPFix foi construído com o propósito único de ser uma ferramenta eficiente e exclusiva para VoIP, possuindo funcionalidades necessárias para dar suporte ao profissional de administração de rede a observar e diagnosticar problemas de telefonia IP.

O trabalho aqui apresentado inclui a investigação de ferramentas relacionadas, descreve os princípios utilizados na arquitetura de construção do VolPFix, seus detalhes de implementação e apresenta testes de correção e desempenho dos algoritmos de análise. 


\section{Abstract}

With recent advances in technologies for data transmission and with the popularization of Internet access via broadband for businesses and home users, IP telephony has become a fact.

Internet phone service providers also called VolP providers appeared to capture this growing market. These companies offer plans with lower rates, especially for long distance and international calls, since their great advantage is the fact the use existing communication networks, such as the Internet.

Despite the benefits that VolP technology has brought, many problems are still faced by users, because the IP telephony system depends heavily on resources that are not under the control of applications and equipments responsible for providing this service.

The VolPFix project, presented in this dissertation, arose from the need for a tool that complements the others in the analysis of computer networks and IP telephony. Professionals working in this market sometimes have limited knowledge of the technologies and protocols of VolP equipments, because they are something very specific.

VolPFix was built with the single purpose of being an efficient and unique tool for VolP, with features required to support the network administrator to observe and diagnose problems in IP telephony.

The work presented here includes an investigation of related tools, the principles used in the construction of the VolPFix architecture, its implementation details and tests of correctness and performance of its analysis algorithms. 


\section{Sumário}

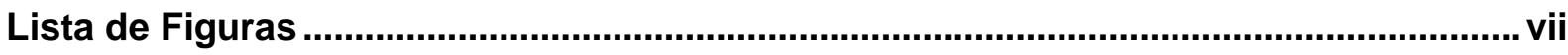

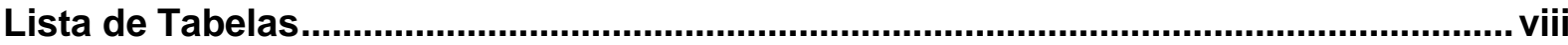

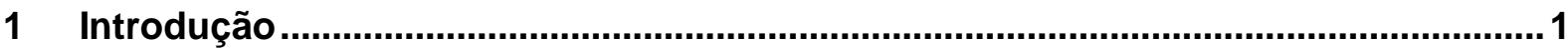

$1.1 \quad$ O Mercado de Telefonia IP

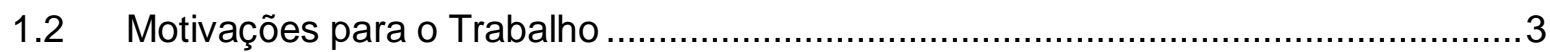

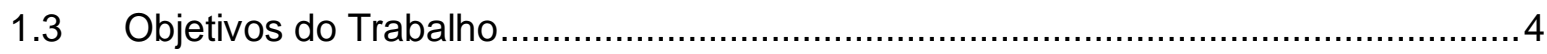

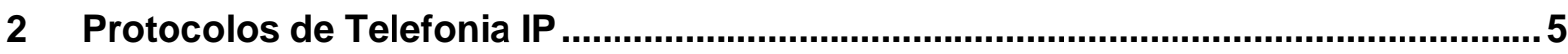

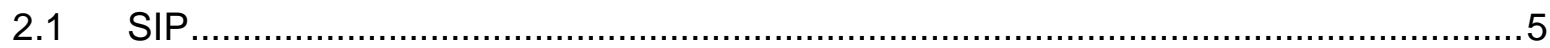

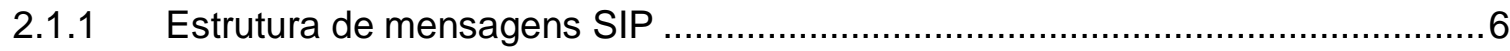

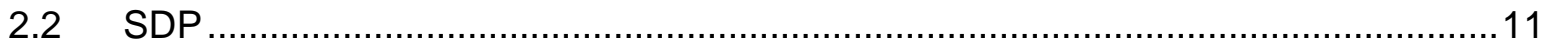

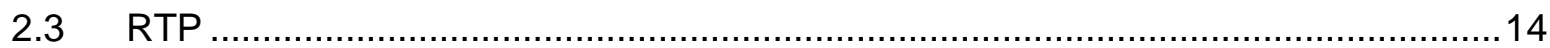

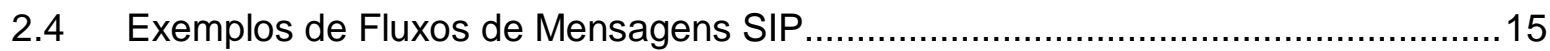

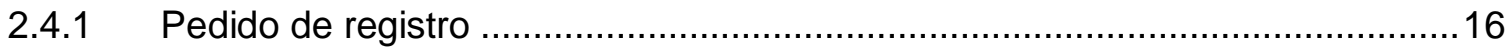

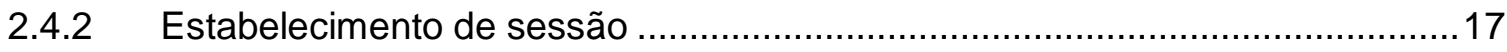

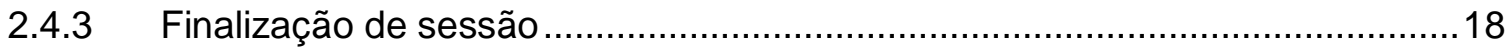

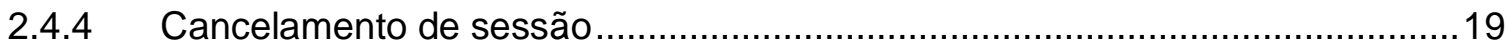

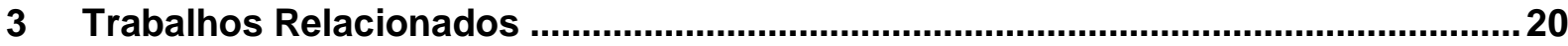

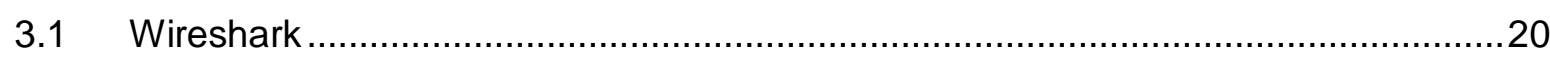

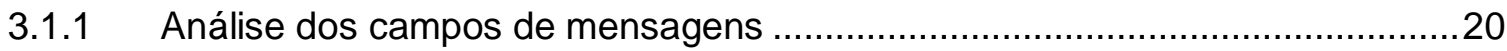

3.1.2 Visualização das transações de chamada.....................................................21

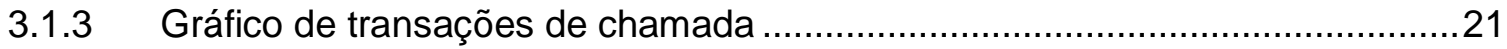

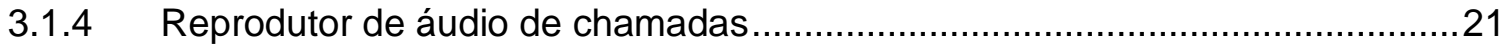

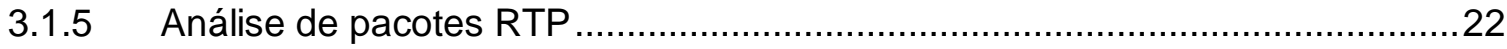

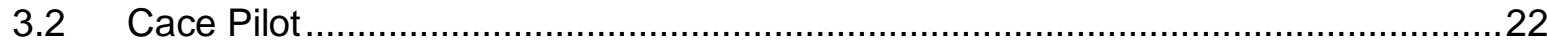

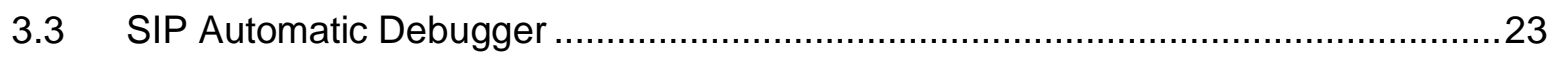

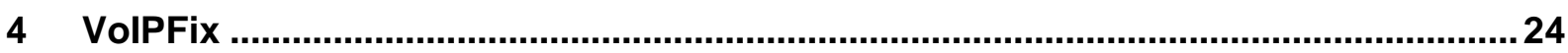

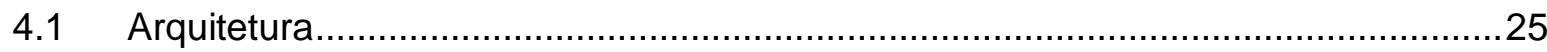

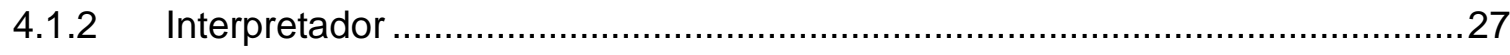

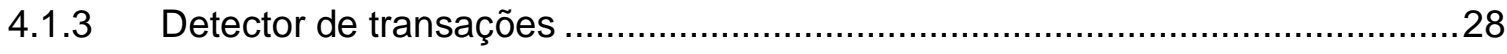

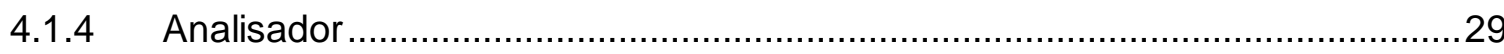

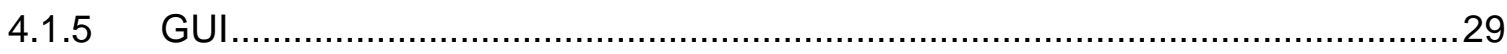

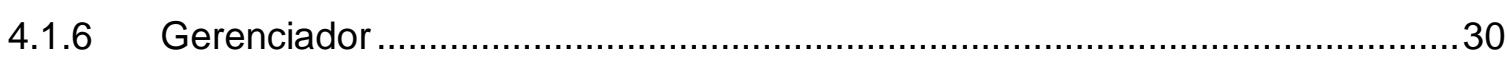

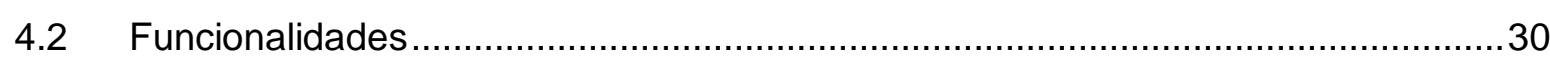

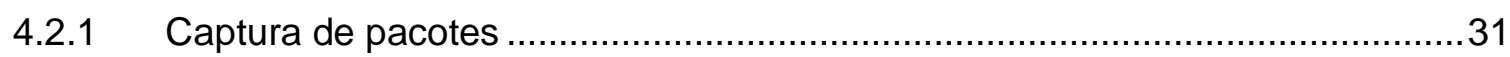

4.2.2 Análise de pacotes de forma eficiente em plataformas multicore......................32 


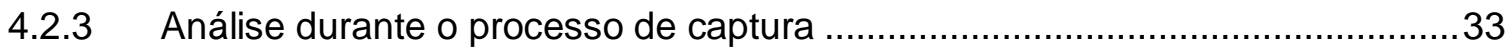

4.2.4 Análise de múltiplos arquivos gravados sequencialmente ...............................33

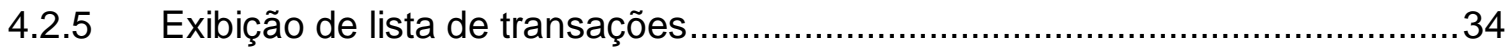

4.2.6 Exibição de detalhes das mensagens de sinalização e voz ..............................36

4.2.7 Exibição de gráfico detalhado de transações .................................................... 38

4.2.8 Exibição de gráfico com número de transações ..............................................41

4.2.9 Exibição de gráfico com estatísticas de fechamento de chamadas..................42

4.2.10 Exibição de gráfico de número de chamadas por usuário ou máquina .............44

4.2.11 Exibição de gráfico com estatísticas de pedidos de registros ...........................48

4.2.12 Exibição de gráfico de número de registros por usuário ou máquina ...............49

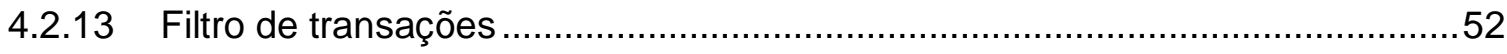

4.2.14 Medição de jitter, perda de pacotes e erros de sequência................................53

4.2.15 Detecção de mudez total ou parcial em chamadas............................................54

4.2.16 Detecção de transações com erros de sinalização .........................................57

4.2.17 Informativo com causas de problemas com transações ...................................59

4.2.18 Reprodução do áudio das chamadas com codificador G.711 .........................60

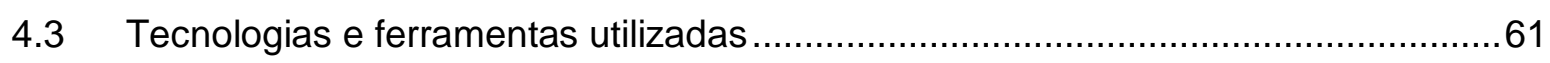

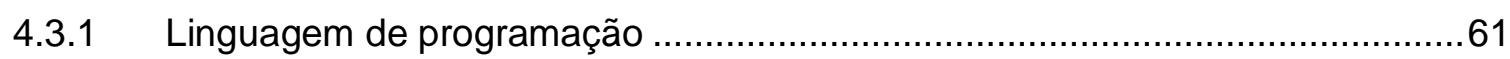

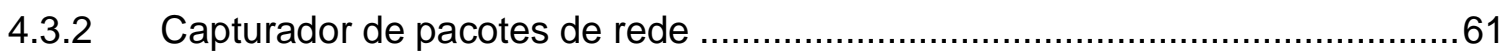

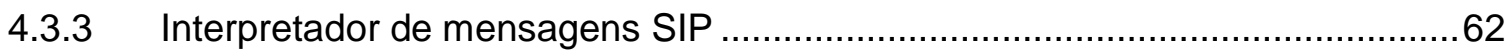

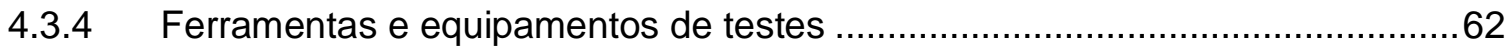

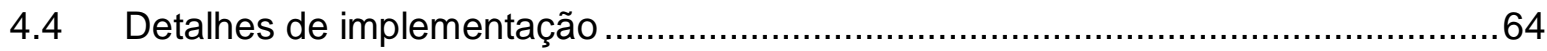

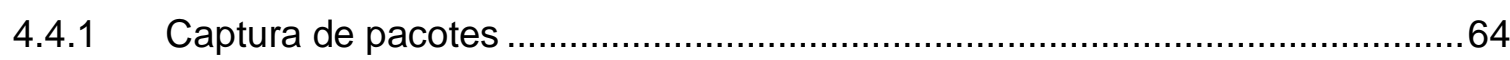

4.4.2 Análise de múltiplos arquivos gravados sequencialmente ...............................65

4.4.3 Identificação de pacotes de interesse ............................................................66

4.4.4 Interpretação dos pacotes de sinalização.....................................................67

4.4.5 Análise de transações de forma eficiente em plataformas multicore ................67

4.4.6 Análise durante o processo de captura ........................................................ 72

4.4.7 Exibição de lista de transações....................................................................73

4.4.8 Exibição de gráfico detalhado de transações ...............................................73

4.4.9 Exibição de gráficos com estatísticas ................................................................ 74

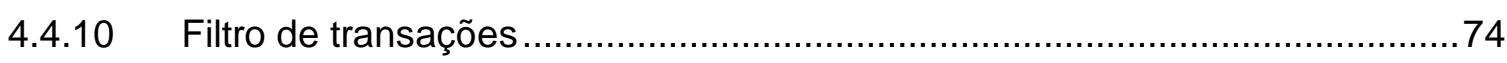

4.4.11 Medição de jitter, perda de pacotes e erros de sequência...............................75

4.4.12 Detecção de mudez total ou parcial em chamadas........................................76

4.4.13 Detecção de transações com erros de sinalização.............................................76

4.4.14 Informativo com causas de problemas com transações .................................79 
4.4.15 Reprodução do áudio das chamadas com codificador G.711 …....................79

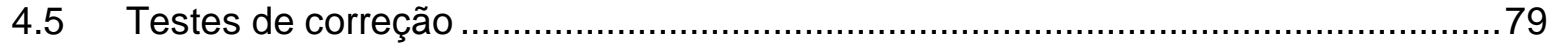

4.5.1 Medição de jitter máximo ........................................................................ 79

4.5.2 Medição de percentual de perda de pacotes ................................................ 80

4.6 Testes de desempenho com abertura de arquivos grandes .................................81

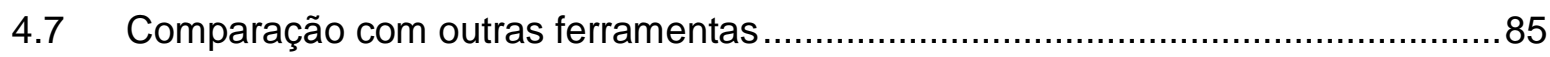

4.7.1 Análise de forma eficiente em plataformas multicore ......................................87

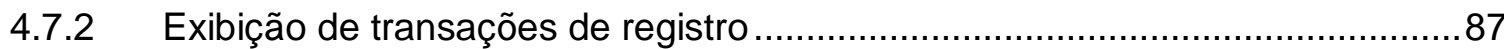

4.7.3 Deteç̧ão de mudez total ou parcial em chamadas .........................................87

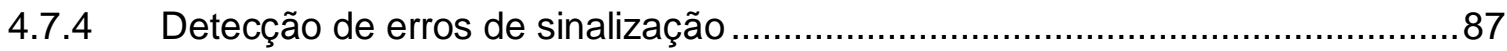

4.7.5 Medição de jitter, perda de pacotes e erros de sequência................................ 88

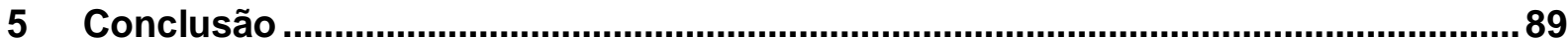

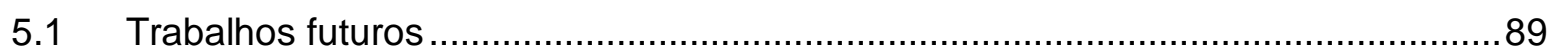

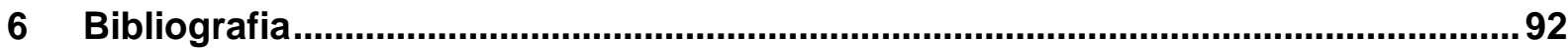




\section{Lista de Figuras}

Figura 1 - Exemplo de mensagem de pedido de registro. ...................................

Figura 2 - Exemplo de mensagem de abertura de sessão.....................................

Figura 3 - Cabeçalho RTP........................................................................ 14

Figura 4 - Fluxo de mensagens para pedido de registro.....................................16

Figura 5 - Fluxo de mensagens para estabelecimento de sessão. …………….....17

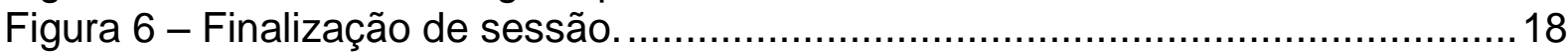

Figura 7 - Cancelamento de sessão. .......................................................... 19

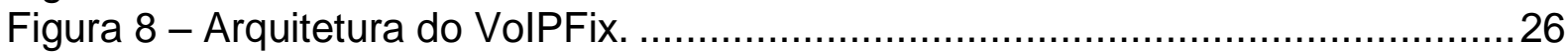

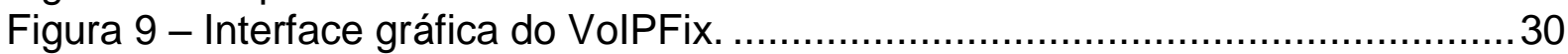

Figura 10 - Tela para iniciar captura de pacotes.................................................. 31

Figura 11 - Analisando pacotes em mais de um thread........................................33

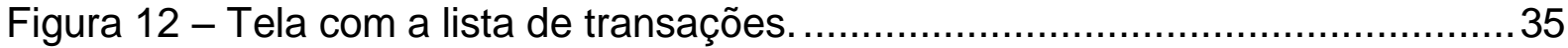

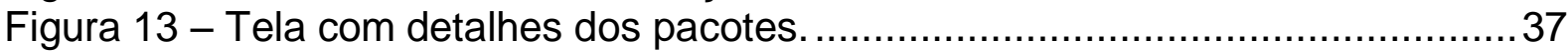

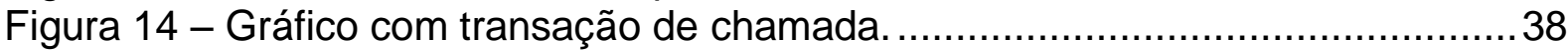

Figura 15 - Gráfico com transação de registro.................................................... 40

Figura 16 - Gráfico com transação de registro e chamada. ..................................41

Figura 17 - Gráfico com número de transações.................................................... 42

Figura 18 - Gráfico com estatísticas de fechamento de chamadas..........................43

Figura 19 - Gráfico com o número de chamadas do usuário. ................................45

Figura 20 - Gráfico com número de chamadas para o usuário. ..............................46 46

Figura 21 - Gráfico com número de chamadas do endereço. ................................47

Figura 22 - Gráfico com número de chamadas para o endereço............................48 48

Figura 23 - Gráfico com estatísticas de pedidos de registro. ..................................49

Figura 24 - Gráfico com número de registros do usuário.....................................50

Figura 25 - Gráfico com número de registros do endereço...................................51

Figura 26 - Gráfico com número de registros para o endereço..............................51

Figura 27 - Tela de filtro de transações. ..........................................................53

Figura 28 - Relatório de jitter, perda de pacotes e erro de sequência......................54

Figura 29 - Detecção de momentos de ausência de fluxo de áudio..........................56

Figura 30 - Deteç̧ão de ausência de fluxo RTP num sentido. ..............................56

Figura 31 - Relatório com problema de sinalização. ..........................................58

Figura 32 - Detecção de problema de fechamento de chamada. ..........................59

Figura 33 - Informativo com problemas de transações. ........................................6

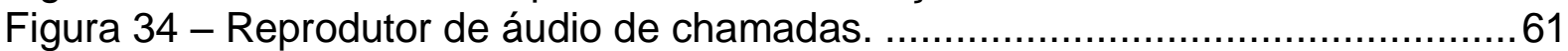

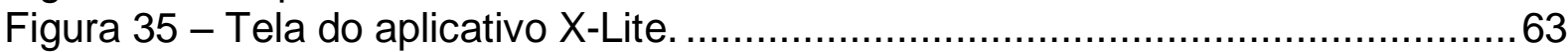

Figura 36 - Interpretação de pacotes em múltiplas tarefas. ....................................69

Figura 37 - Análise em múltiplas tarefas para formação de transações ....................70

Figura 38 - Gráfico de problema de fechamento de chamada. Caso 1 ....................77

Figura 39 - Gráfico de problema de fechamento de chamada. Caso 2 ....................78 


\section{Lista de Tabelas}

Tabela 1 - Milhares de assinantes de VolP das maiores operadoras brasileiras. .......2

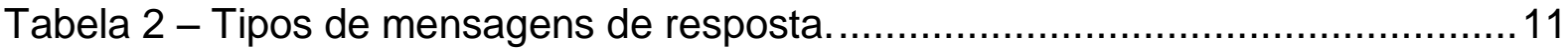

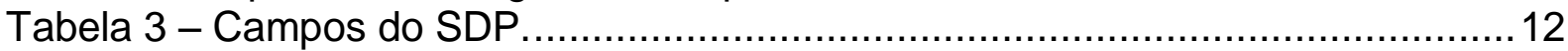

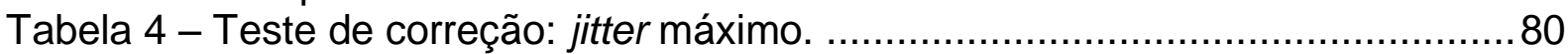

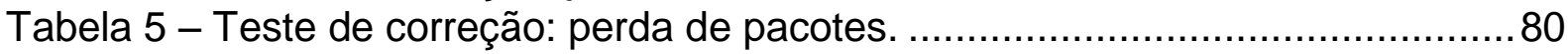

Tabela 6 - Informações sobre máquinas utilizadas nos testes.............................81

Tabela 7 - Tempo de abertura de arquivo com 50 MB...................................... 83

Tabela 8 - Tempo de abertura de arquivo com 100 MB.................................... 84

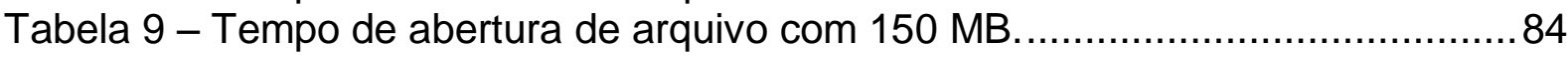

Tabela 10 - Tempo de abertura de arquivo com 200 MB.................................... 84

Tabela 11 - Teste de desempenho em máquina de um núcleo. .............................85

Tabela 12 - Comparativo de funcionalidades com Wireshark e Cace Pilot. ..............86 


\section{Introdução}

As primeiras aplicações de telefonia IP apareceram de forma mais concreta no final da década de 1990, quando começaram a se desenvolver aplicativos para computadores, capazes de transportar a voz codificada e transmitida em pacotes [JOH04]. Com esses programas para telefonia IP, era possível que duas pessoas se comunicassem através da Internet, embora com uma qualidade de voz ainda muito precária.

Alguns protocolos de sinalização, como o H.323 [ITU09] e o MEGACO [CUE00], foram desenvolvidos para a comunicação entre os sistemas de telefonia IP para que pudessem trocar informações e estabelecer uma chamada entre dois computadores. Surgia então a tecnologia chamada de VoIP (Voice over the Internet Protocol).

No início, o grande problema para as aplicações e equipamentos de VolP era com relação à compressão e transmissão da voz digitalizada. Os pacotes que carregavam essa voz compartilhavam os mesmos meios de transmissão ocupados pelo tráfego de dados na Internet, de uma forma completamente diferente da telefonia analógica, que conta com um circuito dedicado entre os interlocutores. Porém, apesar desses e de outros problemas, era evidente que a tecnologia de VoIP traria muitos benefícios para o mundo da telefonia, principalmente no que diz respeito à redução do custo das chamadas.

Em 1997, o IETF (Internet Engineering Task Force) [IETF] começou a desenvolver outro protocolo de sinalização, que poderia ser utilizado para telefonia IP e também para outros tipos de aplicações. Esse protocolo, que recebeu o nome de SIP (Session Initiation Protoco), é atualmente o mais utilizado pelos aplicativos e equipamentos de telefonia IP. A segunda e atual versão revisada foi publicada em junho de 2002 como sendo a RFC3261 [ROS02a].

Os protocolos como o SIP são utilizados para iniciar, controlar e encerrar sessões, fazendo apenas o trabalho de sinalização entre os envolvidos, não lidando com questões de voz quando se trata de chamadas. Para tal, existem os protocolos de transporte em tempo real que são utilizados para carregar a voz digitalizada através da rede de comunicação de dados. A técnica de transmitir voz codificada por uma rede de pacotes teve início com experimentos por volta de 1970 [PER03]. Porém o protocolo para transporte de voz mais utilizado, desde o início da telefonia IP até hoje, é o RTP (Real-Time Transport Protocol) [SCH03] desenvolvido também pelo IETF no período entre 1992 e 1996, baseado em outros protocolos com o mesmo objetivo.

O VolPFix já é utilizado como ferramenta, pelo próprio autor desta dissertação, que trabalha na empresa Leucotron Telecom, desenvolvendo equipamentos de comunicação privada (centrais PBX) e soluções de telefonia IP, substituindo o Wireshark em todas as situações como:

- Detecção de eventos anormais no sistema de telefonia principal da empresa;

- análise de problemas em campo;

- verificação de funcionamento de equipamentos de testes em laboratório; 
- medição de jitter e perda de pacotes em ensaios de grande escala.

O VolPFix está disponibilizado como um projeto de software livre através do Centro de Competência de Software Livre do IME-USP, no sítio http://ccsl.ime.usp.br/voipfix, sob a licença GNU General Public License v.3.

\subsection{O Mercado de Telefonia IP}

Com os avanços das tecnologias de transmissão de dados e com a popularização dos acessos à Internet através de banda larga para empresas e usuários domésticos, a telefonia IP tornou-se um fato real. As empresas utilizam de todos os recursos possíveis para que a comunicação tenha, com clientes/fornecedores e colaboradores, um custo menor do que aquele do sistema de telefonia fixa convencional.

As prestadoras de serviço de telefonia IP, também chamadas de operadoras VolP, apareceram para conquistar esse mercado crescente. Essas empresas oferecem planos com tarifas mais reduzidas, principalmente para ligações de longa distância e internacionais, uma vez que a grande vantagem está no fato dela utilizar infraestrutura existente de rede utilizada para transporte de dados, como a Internet.

Além de permitir um custo mais barato para ligações, o usuário de VoIP ainda tem a mobilidade como vantagem, já que é possível se comunicar não importa o local onde se esteja, desde que haja um acesso à Internet com velocidade razoável. Através da telefonia IP é possível realizar ligações de qualquer parte do mundo e para qualquer outra parte do mundo, com tarifas bem reduzidas.

Apesar das grandes vantagens, essa tecnologia ainda apresenta alguns problemas aos usuários, principalmente no que diz respeito à qualidade da chamada. Porém, os benefícios são muito grandes e fazem com que o mercado cresça a cada dia. Apenas as vantagens de redução de custos e mobilidade já são grandes motivos para que essa tecnologia seja bastante utilizada.

Segundo informações do sítio Teleco [TELE], computando apenas os serviços das duas maiores operadoras de telefonia IP do Brasil, que são a Embratel e a GVT, o crescimento de assinantes nos últimos anos foi muito grande, como pode ser visto na Tabela 1:

\begin{tabular}{|l||c||c||c|}
\hline Milhares & $\mathbf{2 0 0 8}$ & $\mathbf{2 0 0 9}$ & $\mathbf{2 0 1 0}$ \\
\hline \hline Embratel & 1802 & 2557 & 2765 \\
\hline \hline GVT & 100 & 147 & 176 \\
\hline
\end{tabular}

Tabela 1 - Milhares de assinantes de VoIP das maiores operadoras brasileiras. Fonte: www.teleco.com.br 
Esses dados levam em consideração somente os assinantes pagantes do serviço de telefonia IP das operadoras citadas. Ainda há um número grande de usuários em outras operadoras e outros serviços privados que são utilizados para realizar interligação entre centrais de uma mesma empresa, escritórios e residências. Porém, é evidente o crescimento nos últimos anos de usuários pagantes.

Além dessas operadoras, ainda há o serviço de telefonia IP oferecido pelo Skype, que, além de outras funcionalidades, permite que usuários utilizem a Internet para realizar ligações para telefones fixos, móveis e para outros usuários, com preços competitivos. Esse trabalho não cita maiores detalhes sobre essa aplicação, pois o Skype utiliza um protocolo de sinalização proprietário [BS06].

\subsection{Motivações para o Trabalho}

Apesar dos benefícios que a tecnologia VolP trouxe, muitos problemas são enfrentados pelos usuários, pois o sistema de telefonia IP depende fortemente de recursos que não estão sob o controle das aplicações e equipamentos responsáveis por oferecer esse serviço [KP09]. Alguns dos problemas são:

- Degradação da qualidade de voz;

- ausência de áudio em um ou ambos os sentidos;

- queda de ligações;

- indisponibilidade do serviço de telefonia.

Alguns desses problemas são causados principalmente pelas condições da rede por onde os pacotes de sinalização e voz estão trafegando, pois, normalmente, eles estão compartilhando o meio de transmissão com outros pacotes da rede. Tais problemas da telefonia IP podem ser causados por:

- Largura de banda de rede insuficiente para transmissão de voz;

- regras de priorização de pacotes inadequadas em equipamentos de roteamento;

- regras de redirecionamento de pacotes incoerentes em equipamentos de roteamento para funcionamento de serviços de VolP;

- instabilidade de elementos de rede ou meios de transmissão.

As causas dos problemas de um sistema de telefonia IP são relativamente bem conhecidas, mas são muito difíceis de serem diagnosticadas, envolvendo análise de grande quantidade de dados.

Este trabalho apresenta o desenvolvimento do VolPFix [VOIP], uma ferramenta específica de análise de casos que utilizem VolP, do ponto de vista de pacotes de sinalização e voz. Alguns dos objetivos são:

- Capturar e analisar de forma eficiente, pacotes de sinalização e voz;

- exibir relatórios das ligações, informando dados como perda de pacotes, jitter, qualidade de voz da ligação; 
- informar problemas relativos à sinalização nas chamadas e nos pedidos de registro;

- permitir a operação e o diagnóstico de problemas por usuários que tenham conhecimento básico de VolP.

\subsection{Objetivos do Trabalho}

Este trabalho tem os seguintes objetivos:

- Investigar criticamente outras ferramentas conceituadas de monitoramento e análise de VolP, citando suas limitações;

- propor novas funções para torná-las mais adequadas aos usuários com pouco conhecimento na tecnologia e protocolos;

- desenvolver uma nova ferramenta capaz de resolver parte das limitações trazendo maior facilidade de avaliação em questões de VoIP;

- apresentar um estudo dos problemas mais comuns de sinalização e tráfego de voz;

- propor novas técnicas de diagnóstico, análise de protocolos de sinalização e implementá-las na nova ferramenta proposta, o VolPFix.

A organização desta dissertação é a seguinte: o Capítulo 2 apresenta os conceitos básicos dos protocolos de telefonia IP, como o SIP e o RTP, necessários para o entendimento do trabalho e fundamentais para o funcionamento do VolPFix. Traz também alguns exemplos de fluxos de mensagens de sinalização. O Capítulo 3 descreve o estado da arte e os principais trabalhos relacionados. O Capítulo 4 detalha o sistema proposto com os objetivos principais, detalhes de implementação da ferramenta e testes de correção e desempenho. Por último, o Capítulo 5 traz a conclusão sobre a pesquisa e aponta para possíveis caminhos para trabalhos futuros. 


\section{Protocolos de Telefonia IP}

A tecnologia de VolP utiliza-se de dois tipos básicos de protocolos para o seu funcionamento:

- Protocolo de sinalização: responsável pelo estabelecimento, controle e encerramento das chamadas;

- protocolo de transporte de voz: responsável por trafegar a voz digitalizada e codificada através da rede de comutação de pacotes.

Durante a evolução da telefonia IP, muitos protocolos de sinalização foram desenvolvidos e utilizados, porém, atualmente, o protocolo mais utilizado é o SIP. Por tal motivo, este trabalho trata somente dos casos onde esse protocolo é utilizado. Não haverá nenhuma perda de funcionalidade, já que quase a totalidade das aplicações utiliza esse protocolo.

Em relação ao protocolo para transporte de voz, o mais utilizado, desde as primeiras aplicações de telefonia IP, é o RTP, que, independentemente do tipo do protocolo de sinalização, pode ser utilizado para transportar os pacotes de voz digitalizados e codificados através da rede de comutação de pacotes.

A seguir, serão descrito com mais detalhes esses dois protocolos e alguns outros pontos chaves para o bom entendimento dos propósitos deste trabalho. Os conceitos mostrados têm a profundidade necessária para que se possa entender os objetivos do trabalho e os pontos chaves das tarefas, bem como eles serão apresentados.

\section{$2.1 \quad$ SIP}

O SIP (Session Initiation Protocol) é baseado nos modelos de requisições e respostas do HTTP [FIE99], onde o sistema final que gera requisições é chamado de user agent client (UAC) e o outro, que responde a essas requisições, é chamado de user agent server (UAS).

As mensagens SIP trocadas entre os agentes podem ser transportadas por UDP [POS80a] ou TCP [POS80b], porém a maioria das aplicações utiliza somente o UDP.

Dois conceitos são importantes para entendimento da mecânica das máquinas de estado que regem as requisições e respostas do SIP, são eles: a sessão e a transação.

A sessão é uma coleção de fluxos de mídia, como áudio, vídeo ou texto, com o propósito de se iniciar uma comunicação entre dois ou mais participantes. Para o estabelecimento dessa sessão, alguns parâmetros devem ser negociados durante a sinalização, por exemplo, endereços IP, portas e codificadores de áudio/vídeo. Tais parâmetros são fornecidos em mensagens SIP que contêm outro protocolo chamado SDP (Session Description Protocol) [HAN98].

Uma transação do SIP consiste numa requisição do cliente que invoca um método particular (função) no servidor e esse responde com a mensagem adequada 
para dar continuidade ao atendimento dessa requisição. Na especificação original do SIP, seis métodos estão definidos:

- REGISTER: para registrar informações de contato e localização do usuário;

- INVITE: para iniciar uma sessão;

- ACK: para confirmar o início de uma sessão;

- CANCEL: para cancelar uma sessão que está iniciando;

- BYE: para terminar uma sessão estabelecida;

- OPTIONS: para requisitar as capacidades de um agente.

Outros métodos, como INFO [DON00], MESSAGE [CAM02], PRACK [RS02a], UPDATE [ROS02b], REFER [SPA03] e NOTIFY [ROA03] foram definidos para estender as possibilidades do SIP e implementar outros tipos de serviços de telefonia.

As requisições são recebidas ou geradas por servidores que estão presentes num sistema de telefonia IP. Conceitualmente, os três tipos de servidores numa arquitetura SIP, são:

- Servidores de encaminhamento: ajudam a encaminhar as requisições para os destinos corretos dos usuários;

- servidores de registro: permitem que os usuários possam informar o endereço na rede para que os outros servidores possam consultar e encontrar onde está um determinado usuário;

- servidores de redirecionamento: ajudam a encontrar caminhos alternativos onde os usuários possam ser encontrados.

Conceitualmente, os servidores no sistema de telefonia IP são considerados como aplicações fisicamente separadas, porém nada impede que os três tipos estejam instalados e em execução em um mesmo computador servidor.

\subsubsection{Estrutura de mensagens SIP}

O SIP é um protocolo baseado em texto, que utiliza o conjunto de caracteres do UTF-8 [YER98]. As mensagens que são trocadas entre os agentes de uma sessão seguem o mesmo padrão das requisições HTTP, onde há uma parte que é o cabeçalho, com campos específicos dependendo do tipo da mensagem, e um corpo, onde há informações sobre a mídia da sessão que será estabelecida.

No repertório do SIP, as mensagens são divididas em requisição e resposta. As mensagens de requisição solicitam métodos específicos em um agente, como, por exemplo, solicitar o início de uma sessão de voz, cancelar uma sessão de voz no processo de estabelecimento e encerrar uma sessão de voz depois de estabelecida. Além disso, tais mensagens podem solicitar o registro em um servidor e algumas outras funções já definidas. 

relevância.

A seguir, um detalhamento das duas mensagens de requisição de maior

\subsubsection{Mensagem de requisição de registro}

A mensagem de REGISTER, enviada por um UAC, solicita ao servidor de registro que o adicione em sua lista de usuários presentes na rede, para que outros servidores ou usuários possam encontrá-lo. Tal mensagem contém apenas o cabeçalho e seus campos, já que não será estabelecida nenhuma sessão de mídia entre o usuário e o servidor. Outras mensagens serão trocadas entre o UAC e o servidor para completar a transação até que o registro seja efetivamente concluído. Essas outras mensagens serão mostradas na Seção 2.4 que trata dos fluxos de mensagens SIP.

A Figura 1 traz um exemplo de mensagem de requisição REGISTER.

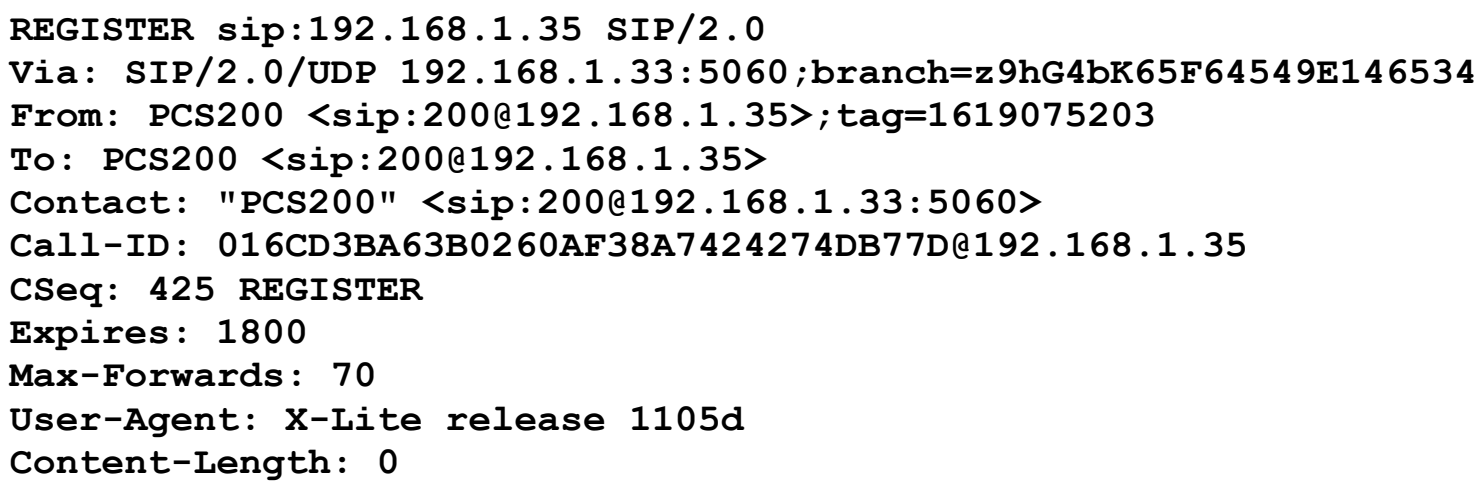

Figura 1 - Exemplo de mensagem de pedido de registro.

A primeira linha, chamada de linha de requisição, informa basicamente o método (REGISTER) invocado pelo agente que gerou a mensagem e o endereço do servidor no qual ele deseja invocar o método.

As demais linhas são os campos do cabeçalho da mensagem REGISTER, e trazem informações relevantes à identificação e localidade do usuário requisitante, bem como a forma de realizar o registro no servidor.

Dependendo do tipo da mensagem SIP, há campos que são obrigatórios. No caso de mensagens de registro como a transcrita acima, segundo a RFC3261, os campos obrigatórios são:

- Call-ID: contém um identificador único da transação. Esse número é gerado pelo solicitante e deve ser diferente a cada pedido de uma nova transação; 
- CSeq: formado por um número de sequência que deve ser incrementado a cada pedido. Também informa o método no qual o número de sequência se refere;

- From: traz informações de localização do requisitante;

- Max-Forwards: em caso de utilização de proxies entre o requisitante e o servidor, este número é decrementado a cada passagem por um proxy, evitando assim laços infinitos;

- To: é onde o servidor coleta a informação de qual é o usuário que está solicitando o registro. Normalmente o campo From contém os mesmos valores presentes no campo To;

- Via: traz informações por quais estações a mensagem passou. No caso de haver somente um campo Via, a informação refere-se ao endereço IP e a porta onde o usuário está.

Dependendo da forma de registro que está sendo feita, outros campos são obrigatórios, por exemplo, quando o servidor solicita uma autenticação para realizar o registro. Nesse caso, o campo Authorization é necessário e irá trazer informações da autenticação solicitada pelo servidor e a senha criptografada que dará acesso ao pedido de registro.

Outros campos são opcionais e trazem informações adicionais sobre o usuário requisitante:

- Contact: contém informações de rota para acesso ao usuário requisitante, como o endereço IP e a porta;

- Expires: informa o tempo em segundos que o solicitante do registro deseja que o servidor considere válido. Durante esse tempo o servidor de registro irá manter as informações do pedido em sua tabela, devendo o solicitante gerar um novo pedido antes que o tempo acabe, renovando a tabela do servidor;

- User-Agent: contém o nome do agente que gerou a mensagem. Geralmente, é a identificação do aplicativo que está sendo utilizado e a versão do mesmo;

- Content-Length: informa o tamanho em bytes do corpo da mensagem. No caso de uma mensagem de registro, como não há nenhum dado no corpo da mensagem, o valor informado é zero.

\subsubsection{Mensagem de requisição de início de sessão}

A mensagem de INVITE é utilizada quando um UAC deseja iniciar uma sessão de voz, vídeo ou texto com outro agente. Ela pode ser enviada diretamente ao destino com o qual se deseja estabelecer a sessão, ou pode passar por um servidor proxy, que a encaminhará ao destino final. Assim como na transação de pedido de registro, a mensagem de INVITE é somente a primeira que dá início ao processo. Outras mensagens são trocadas entre o UAC e o destino para dar continuidade até a finalização da transação de início de sessão. Tais mensagens serão mostradas na Seção 2.4 que cita exemplos de fluxos de mensagens SIP. 
O exemplo a seguir é de uma mensagem originada pelo usuário de nome 200 que deseja estabelecer uma sessão de voz com o usuário de nome 201.

A Figura 2 contém um exemplo de mensagem para abertura de sessão.

No caso de um sistema de telefonia, os nomes, que estão nos campos From e To, são os números dos telefones dos usuários. No exemplo abaixo, eles aparecem entre sip: e o @ e são os números 200 e 201. Esses números fazem parte do plano de numeração e podem ser discados por qualquer outro telefone num sistema híbrido (composto por telefones IP e telefones analógicos convencionais). Regularmente, são apenas dígitos discáveis de um teclado de telefone convencional, mas podem ser compostos por caracteres alfanuméricos.

A informação que aparece logo após o nome do campo From é chamada de display name, e no exemplo utilizado na Figura 2 abaixo é o PCS200, que representa simplesmente uma identificação a ser exibida no destino. Normalmente, o UAS que recebe a requisição utiliza essa informação para exibi-la em um visor.

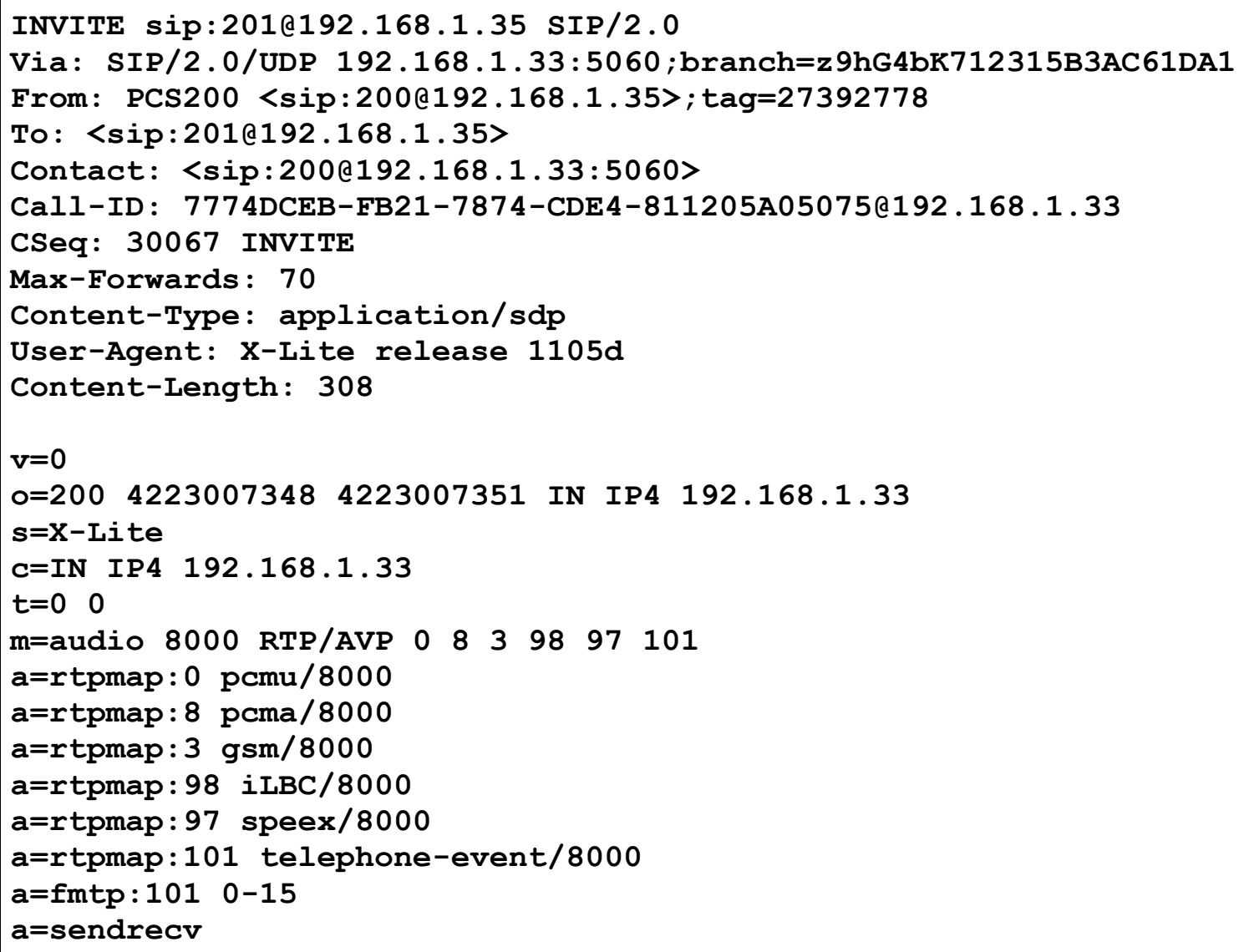

Figura 2 - Exemplo de mensagem de abertura de sessão. 
O cabeçalho da mensagem de INVITE, que vai da primeira linha até Content-Length, tem alguns campos parecidos com 0 da mensagem de REGISTER, por exemplo, Via, Contact, Call-ID, Max-Forwards e UserAgent. O conteúdo desses campos são parecidos com o da mensagem de registro, mas alguns deles têm utilidades diferentes, pois o UAS que recebe a mensagem utiliza as informações para encaminhar a ligação a um destino, ou mesmo atender e dar continuidade ao processo de abertura da sessão.

A primeira linha, que é a chamada linha de requisição, contém o método (INVITE) que é invocado no UAS, além do número do destino da requisição (201) e o endereço IP onde ele está registrado (192.168.1.35).

Diferente da mensagem de registro, o campo To contém a informação de qual usuário a requisição tem como alvo e também o endereço IP do servidor de encaminhamento.

Os campos Content-Type e Content-Length contêm, respectivamente, o tipo e o tamanho da informação que está no corpo da mensagem.

Nesse tipo de mensagem, os campos obrigatórios são: Call-ID, Contact, Cseq, From, Max-Forwards, To e Via.

\subsubsection{Mensagens de resposta}

Uma mensagem SIP de resposta é aquela gerada por um UAS ou por um servidor para responder a uma requisição de um UAC. Ela pode conter campos adicionais com informações necessárias ao UAC ou somente reconhecer 0 recebimento da requisição, evitando retransmissões pelo UAC. Muitas das mensagens de resposta também levam o UAC a movimentar sua máquina de estado de controle da transação.

As mensagens de resposta são divididas em seis classes e têm sua utilização de acordo com a requisição em andamento e o estado da mesma. Os tipos de classes são mostrados na Tabela 2. 


\begin{tabular}{|l||l||l||}
\hline Classe & Descrição & Ação \\
\hline \hline $1 \mathrm{xx}$ & Informativa & $\begin{array}{l}\text { Indica o status da chamada antes da conclusão. Se for } \\
\text { primeira resposta, é informativa ou provisional. }\end{array}$ \\
\hline \hline $2 x x$ & Sucesso & $\begin{array}{l}\text { A requisição foi bem sucedida. Se for um INVITE, um } \\
\text { ACK deve ser enviado, senão interrompe a } \\
\text { retransmissão da requisição. }\end{array}$ \\
\hline \hline $3 x x$ & Redirecionamento & $\begin{array}{l}\text { O servidor retornou outros possíveis locais. O cliente } \\
\text { pode repetir a requisição em outro servidor. }\end{array}$ \\
\hline \hline $4 x x$ & Erro pelo cliente & $\begin{array}{l}\text { A requisição falhou por um erro do cliente. O cliente } \\
\text { deve repetir a requisição, reformulando-a com os } \\
\text { parâmetros da mensagem de resposta. }\end{array}$ \\
\hline \hline $5 x x$ & Falha do servidor & $\begin{array}{l}\text { A requisição falhou por um erro do servidor. O cliente } \\
\text { deve repetir em outro servidor. }\end{array}$ \\
\hline \hline $6 x x$ & Falha global & $\begin{array}{l}\text { A requisição falhou. A requisição não deve ser enviada } \\
\text { novamente a nenhum servidor. }\end{array}$ \\
\hline \hline
\end{tabular}

Tabela 2 - Tipos de mensagens de resposta.

\subsection{SDP}

Após o fim do cabeçalho do exemplo da mensagem de requisição de início de sessão da Figura 2, aparecem, no corpo da mensagem de INVITE, as informações relativas à sessão que o UAC deseja estabelecer [RS02b]. Esse outro protocolo é chamado de SDP, tendo na primeira linha a informação $\mathrm{v}=0$, que é o primeiro campo obrigatório do SDP.

O SDP, definido pela RFC2327 [HAN98], é composto por uma série de linhas, denominadas de campos, cujos nomes são abreviados por uma única letra e estão numa ordem estabelecida para facilitar o trabalho do interpretador.

A Tabela 3 lista os possíveis campos do SDP, quais são obrigatórios, os que são opcionais e faz uma breve descrição sobre cada um. 


\begin{tabular}{|c|c|c|}
\hline Campo & Nome & Obrigatório \\
\hline$V=$ & Versão do protocolo & Sim \\
\hline $0=$ & Criador e identificador da sessão & Sim \\
\hline$S=$ & Nome da sessão & Sim \\
\hline $\mathrm{i}=$ & Informação da sessão & Não \\
\hline$u=$ & URI & Não \\
\hline$e=$ & Endereço de e-mail & Não \\
\hline$p=$ & Número do telefone & Não \\
\hline $\mathrm{C}=$ & Informação da conexão & Sim \\
\hline$b=$ & Informações do consumo de banda & Não \\
\hline$t=$ & Tempo de início e finalização da sessão & Sim \\
\hline$r=$ & Número de repetições & Não \\
\hline$z=$ & Correções de fuso horário & Não \\
\hline$k=$ & Chave de criptografia & Não \\
\hline$a=$ & Linha de atributos da sessão & Não \\
\hline$m=$ & Informações da mídia & Não \\
\hline$a=$ & Atributos de uma mídia & Não \\
\hline
\end{tabular}

\section{Tabela 3 - Campos do SDP.}

No exemplo da mensagem de INVITE, os campos que são obrigatórios do SDP são especialmente tratados pelo UAS que recebe a requisição. É a partir desses campos que são extraídas as informações de quais codificadores poderão ser utilizados, além dos endereços IP e porta destinos para o fluxo de mídia. Abaixo, os campos que merecem uma atenção especial: 
a) Criador da sessão: o campo o contém informações sobre o originador. É utilizado unicamente como um identificador da sessão. O campo é formado pelos seguintes parâmetros:

$0=$ username session-id version network-type address-type address

O username contém o usuário do originador. O parâmetro session-id pode ser um número aleatório ou a hora atual retornada pelo Network Time Protocol (NTP), para garantir um número único. O version é um campo numérico que é incrementado a cada mudança na sessão e também é recomendado que seja utilizado o valor retornado pelo NTP. O network-type tem sempre o valor IN para Internet. O address-type pode ser IP4, para endereços IPv4; ou IP6, para IPv6. O address contém o endereço IP do criador da sessão.

b) Informação da conexão: o campo c contém dados sobre a conexão de mídia e tem o seguinte formato:

C=network-type address-type connection-address

Os parâmetros network-type e address-type têm o mesmo significado que no campo criador da sessão, mas as informações aqui são relativas à conexão de mídia. O campo connection-address contém o endereço IP para onde os pacotes do fluxo de mídia devem ser enviados. É importante ressaltar que o endereço IP desse campo pode não ter o mesmo valor do endereço IP que está no campo o, por exemplo, quando o criador da sessão, que é quem gera a sinalização, está localizado num IP diferente do gateway que irá receber os pacotes do fluxo de mídia.

c) Informações da mídia: o campo m contém informações sobre o tipo de mídia da sessão e tem o seguinte formato:

$\mathrm{m}=$ media port transport format-list

O parâmetro media pode ser audio, video, application, data, telephone-event ou control e indica qual o tipo de mídia que será usada na sessão descrita. $O$ parâmetro port contém o número da porta no qual os pacotes do fluxo de mídia devem ser enviados. O transport contém o protocolo de transporte e pode ser RTP/AVP (real-time transport protocol/audio video profiles) ou UDP. O último parâmetro, format-list, contém os tipos de codificadores utilizados para transporte do fluxo de mídia. Mais de um codificador pode ser definido, sugerindo quais os tipos de codificadores que o originador da sessão aceita.

d) Atributos da mídia: o campo a contém atributos da sessão de mídia. Esse campo pode ser usado para descrever mais detalhes sobre os codificadores informados no campo m. 


\section{$2.3 \quad$ RTP}

O RTP foi desenvolvido para permitir o transporte de pacotes em tempo real contendo voz, vídeo ou outra informação sobre IP. Esse protocolo foi definido pelo IETF e está descrito na RFC3550.

O RTP não fornece nenhuma qualidade de serviço por si só através da rede, pois os pacotes são tratados da mesma forma que todos os outros na rede [PER03]. Porém ele permite a detecção de problemas introduzidos pela rede IP, como:

- Perda de pacotes;

- variações de atraso no transporte (jitter);

- pacotes chegando fora da sequência em que foram enviados.

Os dados dos pacotes RTP não estão em formato de texto, mas sim binário, como os cabeçalhos do UDP e do IP. O RTP foi projetado para ser bastante genérico e alguns campos do cabeçalho não são utilizados por determinadas aplicações. A versão atual do protocolo é a de número 2 e o formato do cabeçalho, composto por 12 octetos, é mostrado a seguir:

\begin{tabular}{|c|c|c|c|c|c|c|c|}
\hline bit offset & $0-1$ & 2 & 3 & 4-7 & 8 & $9-15$ & $16-31$ \\
\hline 0 & $\mathrm{~V}$ & $\mathrm{P}$ & $\mathrm{X}$ & CC & $\mathrm{M}$ & PT & Sequence Number \\
\hline 32 & \multicolumn{7}{|c|}{ Timestamp } \\
\hline 64 & \multicolumn{7}{|c|}{ SSRC identifier } \\
\hline 96 & \multicolumn{7}{|c|}{ CSRC identifiers } \\
\hline $96+32^{\star} \mathrm{CC}$ & \multicolumn{6}{|c|}{$\begin{array}{c}\text { Profile-specific extension } \\
\text { header ID }\end{array}$} & Extension header length \\
\hline $128+32^{*} \mathrm{CC}$ & \multicolumn{7}{|c|}{ Extension header } \\
\hline
\end{tabular}

Figura 3 - Cabeçalho RTP.

a) Versão (V): dois bits que indicam a versão do protocolo. A versão atual é dois.

b) Enchimento $(\mathrm{P})$ : se está com valor um, significa que há octetos de enchimento adicionados no fim do pacote para torná-lo com um comprimento fixo. Esse campo é normalmente utilizado quando se usa fluxo com criptografia.

c) Extensão $(X)$ : se está com valor um, há extensões adicionais no cabeçalho. Extensões são definidas por certos tipos de dados.

d) Contador CSRC (CC): campo com quatro bits que contém o número de identificadores da fonte de contribuição presente no cabeçalho. É utilizado somente por um misturador que coleta vários fluxos RTP e gera somente um, como acontece quando há uma conferência.

e) Marcador (M): bit utilizado para indicar o início da transmissão de um novo quadro no vídeo ou a retomada de uma fala, quando se utiliza supressão de silêncio. 
f) Tipo dos dados (PT): campo com sete bits, indica o codificador que é utilizado para transportar os dados após o cabeçalho. $O$ valor dele coincide com o codificador que foi negociado no SDP.

g) Número de sequência (Sequence Number): campo com 16 bits, incrementado a cada pacote RTP que é enviado. É utilizado pelo receptor para detectar a falta de um pacote ou a chegada em ordem incorreta.

h) Marcador de tempo (TimeStamp): campo de 32 bits que indica um tempo relativo quando o dado foi amostrado. Permite que o receptor retire os atrasos dos pacotes e reproduza o fluxo no tempo correto, considerando que haja uma fila de armazenagem suficiente para os pacotes atrasados.

i) Identificador da fonte de sincronização (SSRCI): campo de 32 bits que identifica o gerador de um fluxo RTP. No início da transmissão dos pacotes RTP, cada gerador escolhe aleatoriamente um número para ser transmitido. Caso aconteça coincidência na escolha do valor do identificador da fonte de sincronização, um novo número é escolhido, até que haja somente identificadores únicos.

j) Identificador da fonte de contribuição (CSRC): pode haver de zero a 15 instâncias desse campo de 32 bits no cabeçalho. A quantidade é informada no campo contador de CSRC. Só existe quando os pacotes são transmitidos por um misturador.

k) Dados: campo onde a informação de voz ou vídeo é transportada, de acordo com o codificador que foi escolhido durante a negociação da sessão. Seu tamanho é de acordo com o codificador que é utilizado.

O RTP permite que haja detecção de pacotes perdidos analisando intervalos no número de sequência, assim como pacotes recebidos fora de ordem, mas deixa o decodificador lidar com esses problemas durante a reprodução do fluxo de vídeo ou voz. Por exemplo, um decodificador de vídeo pode compensar a falta de alguns quadros de imagem, repetindo o último quadro de vídeo exibido, enquanto um decodificador de áudio pode inserir o ruído de fundo captado na ligação.

Variações no atraso dos pacotes podem ser detectadas analisando-se cada marcador de tempo presente. No caso de um codificador com taxa de transmissão contínua, como é o caso do PCM, o incremento do valor do marcador de tempo é

linear. A marcação de tempo de amostragem de cada pacote serve para que o decodificador a reproduza os dados dos pacotes em intervalos corretos.

\subsection{Exemplos de Fluxos de Mensagens SIP}

Abaixo, alguns exemplos de fluxo de mensagens SIP [JOH03]. Neles, será mostrado somente um diagrama da troca de mensagens entre o UAS e o UAC.

Como em qualquer outro protocolo, muitas temporizações estão envolvidas numa troca de mensagens entre dois agentes SIP, principalmente quando 0 protocolo de transporte é o UDP. Nos diagramas abaixo, não são mostrados os 
tempos envolvidos entre uma mensagem e outra. Normalmente, um aplicativo de análise do protocolo SIP apenas informa qual foi o tempo entre uma mensagem e outra, não ressaltando os problemas que porventura podem acontecer quando uma mensagem chega num tempo fora da faixa prevista na RFC.

A RFC3261 sugere que para construção de um agente SIP, uma máquina de estado deve controlar toda a transação de acordo com as mensagens que são recebidas ou enviadas e também os tempos envolvidos entre essas mensagens. A cada mensagem enviada por um agente, sua máquina de estado muda para outro passo e, dependendo da mensagem enviada, um temporizador é iniciado. Caso esse temporizador chegue ao fim, a máquina de estado do agente vai para outro passo e poderá enviar uma mensagem solicitando o cancelamento da transação. Se um agente recebe a mensagem de resposta à mensagem enviada, a máquina vai para outro estado, podendo paralisar o temporizador iniciado. Toda essa análise depende do tipo da transação e do estado em que ela se encontra.

A análise das temporizações para verificar se a sinalização trocada entre dois agentes está ou não dentro das recomendações é muito complexa, pois envolve muitos parâmetros e estados das transações entre esses dois agentes, por isso não será objeto de estudo deste trabalho.

\subsubsection{Pedido de registro}

Nesta transação o cliente solicita ao servidor o registro de seu usuário, informando o IP e a porta onde pode ser localizado. Essas informações serão armazenadas pelo servidor em uma tabela de registro e serão utilizadas por ele quando for necessário contatar esse cliente novamente. No caso específico do exemplo da Figura 4, o servidor solicita uma autenticação ao usuário antes de confirmar o registro.

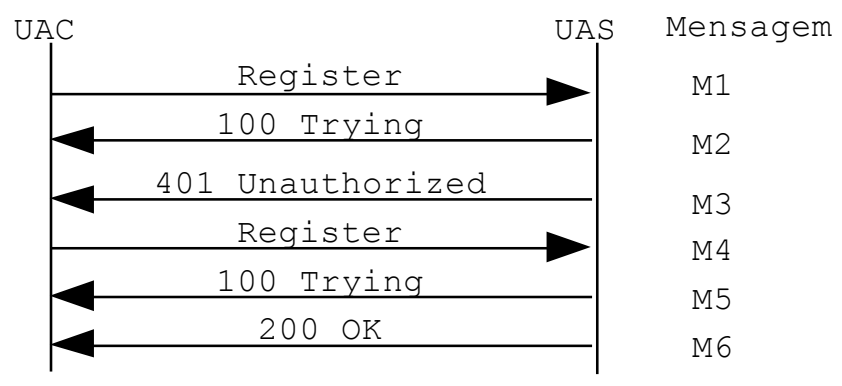

Figura 4 - Fluxo de mensagens para pedido de registro.

- M1: mensagem que dá início à requisição de registro no servidor.

- M2: enviada pelo UAS para indicar que recebeu a solicitação de registro do UAC, e que é para este movimentar sua máquina de estado e interromper a retransmissão do pedido de registro. 
- M3: neste exemplo, o servidor necessita que o usuário se autentique para que o pedido de registro seja aceito. Essa mensagem contém uma chave para que o UAC repita o pedido de registro com o seu usuário e senha criptografados segundo essa chave.

- M4: um novo pedido de registro é gerado com a autenticação solicitada pelo servidor. Nessa mensagem o UAC também pode informar qual o tempo de validade do pedido de registro.

- M5: idem a M2.

- M6: o servidor aceita o pedido de registro, finalizando a transação.

\subsubsection{Estabelecimento de sessão}

Neste exemplo de estabelecimento da sessão são mostradas todas as mensagens trocadas entre um cliente e um servidor, até a última mensagem de atendimento (M7) e o início do fluxo RTP, simbolizado somente por duas setas (M9 e M10).

Especificamente nesse caso, o UAS está solicitando autenticação do UAC para que o estabelecimento da sessão continue. Isso é uma configuração feita no UAS. A Figura 5 mostra esse exemplo.

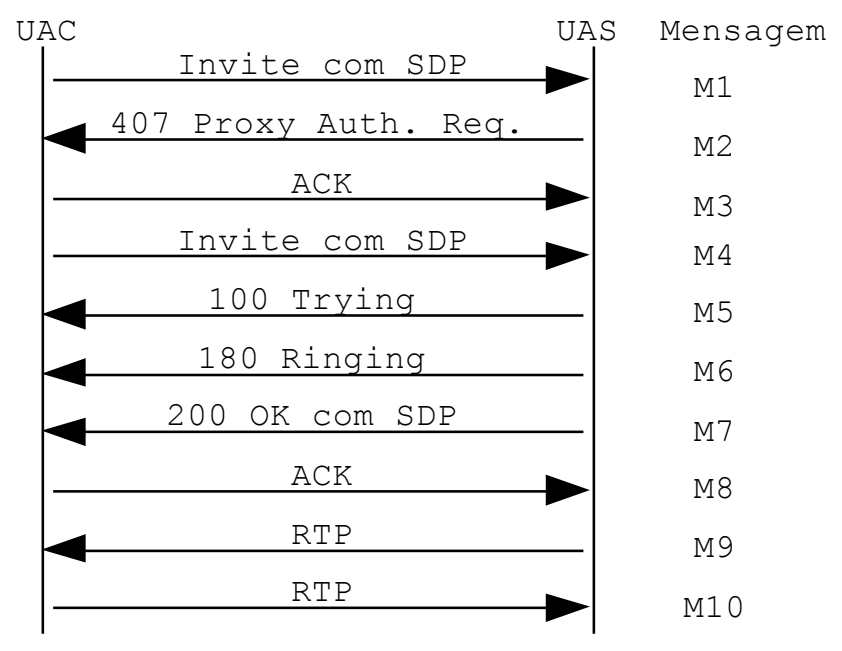

Figura 5 - Fluxo de mensagens para estabelecimento de sessão.

- M1: o UAC solicita ao UAS o início de uma negociação de uma sessão de mídia. Essa mensagem contém em seu corpo o SDP, que é utilizado para detalhar informações sobre os codificadores, endereço IP e porta que serão utilizados durante o fluxo de mídia.

- M2: aqui o UAS solicita que o UAC se autentique, de uma forma semelhante como foi feito na mensagem M3, no exemplo de pedido de registro.

- M3: o cliente confirma e entende a mensagem anterior. 
- M4: um novo pedido é gerado com os dados de autenticação solicitados pelo servidor.

- M5: uma mensagem provisional enviada pelo UAS para indicar que recebeu e está processando a solicitação.

- M6: indica que o alvo da sessão está sendo sinalizado do pedido de abertura de sessão.

- M7: indica que o alvo atendeu ao pedido de abertura de sessão. Como parte do segundo passo da negociação de informações de SDP, o UAS envia nessa mensagem qual ou quais os codificadores que poderá trabalhar durante o fluxo de mídia, além do endereço IP e porta para envio dos pacotes RTP pelo outro lado.

- M8: o UAC concorda com a decisão do UAS com relação à finalização da negociação dos codificadores.

- M9: apenas ilustrativo, indica que o fluxo de RTP está presente no sentindo do UAS para o UAC.

- M10: apenas ilustrativo, indica que o fluxo de RTP está presente no sentido do UAC para o UAS.

O fluxo RTP entre o UAC e o UAS somente representa a presença da mídia estabelecida na sessão, porém ela também pode acontecer envolvendo outros elementos chamados media gateways, que não são agentes usuários, mas sim, conversores de mídia.

\subsubsection{Finalização de sessão}

A finalização da sessão é composta, no exemplo da Figura 6, somente pelas mensagens M11 e M12. A terminação da sessão pode ser iniciada pelo o UAS ou pelo UAC. As outras mensagens acima da mensagem M11 são mostradas apenas para contextualizar.

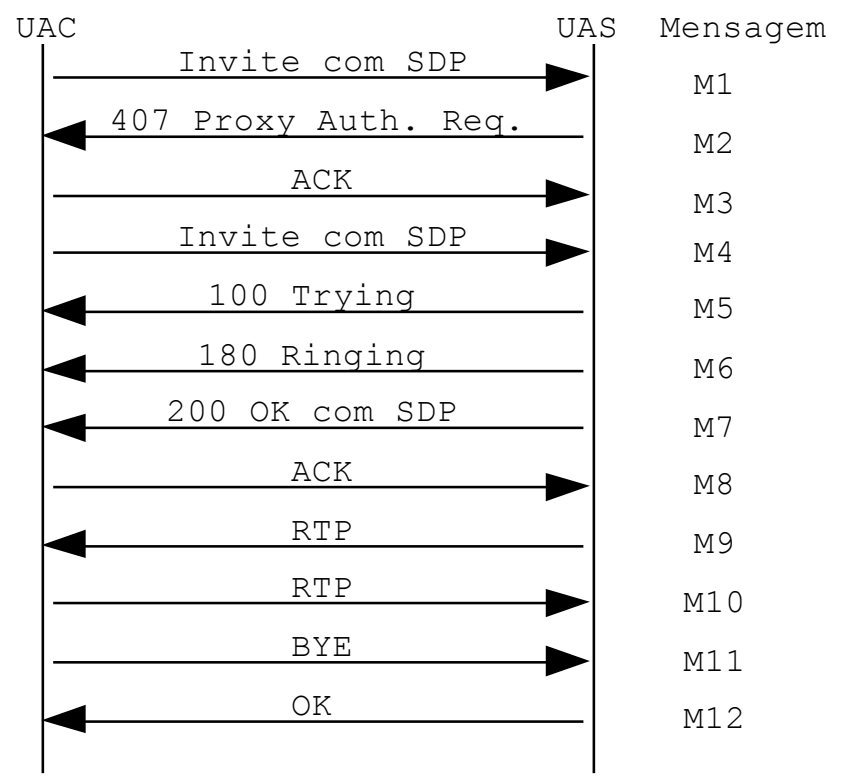

Figura 6 - Finalização de sessão. 
- M1 a M10: conforme descrito no exemplo de estabelecimento de sessão.

- M11: o UAC solicita o encerramento da sessão e do fluxo RTP com o UAS. Essa mensagem poderia ter sido gerada pelo UAS, se ele tivesse encerrado a chamada primeiro.

- M12: o UAS confirma o encerramento da sessão e do fluxo RTP.

\subsubsection{Cancelamento de sessão}

O cancelamento da sessão, neste exemplo, dá-se a partir da mensagem M4. O processo de cancelamento da sessão pode ser iniciado pelo UAC ou pelo UAS, embora, nesse último caso, dependa de funções do aplicativo ou aparelho SIP para cancelar uma chamada recebida sem que antes haja o atendimento da mesma.

No exemplo da Figura 7, pode-se notar que o UAS não solicitou autenticação para o UAC para prosseguir a sessão.

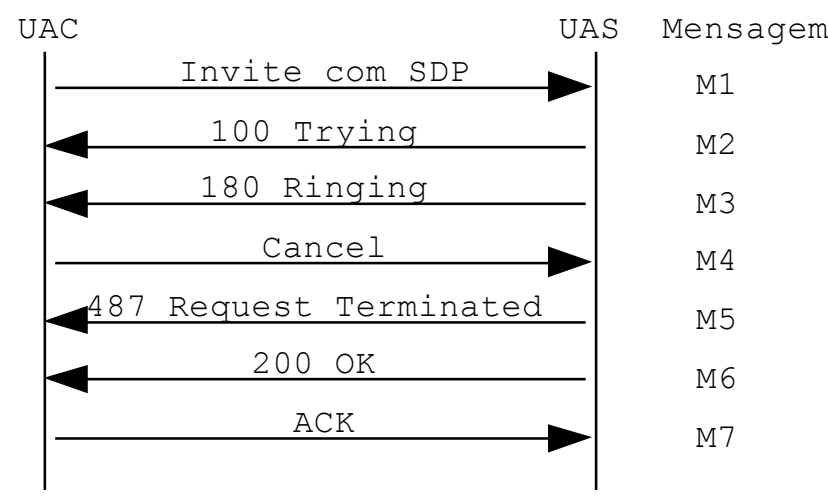

Figura 7 - Cancelamento de sessão.

- M1 a M3: conforme descrito no exemplo de estabelecimento de sessão.

- M4: o UAC solicita o cancelamento do processo de abertura da sessão.

- M5: o UAS informa que a requisição foi terminada.

- M6: o UAS informa que a requisição de abertura de sessão foi cancelada.

- M7: o UAC confirma o recebimento da mensagem anterior. 


\section{Trabalhos Relacionados}

Os trabalhos aqui citados são ferramentas com características semelhantes ao VolPFix, sendo o último deles, o SIP Automatic Debugger, um trabalho acadêmico.

Existem atualmente muitos aplicativos com o propósito de capturar e analisar pacotes de uma rede de computadores. Alguns deles são gratuitos, com o código fonte aberto e outros são comerciais. O objetivo deste capítulo é citar algumas características da parte de análise SIP e RTP de alguns desses aplicativos e fazer uma comparação com o propósito do desenvolvimento do VolPFix.

\subsection{Wireshark}

O projeto do Wireshark [WIREa], começou em 1998, com o nome de Ethereal. Esse aplicativo talvez seja o analisador de protocolos de rede mais conhecido e utilizado ao redor do mundo, com várias características, incluindo uma gama razoável de ferramentas para análise de voz sobre IP, além de ter código fonte aberto com licença GPL. Algumas de suas principais características são:

- Analisa vários tipos de protocolos de rede;

- permite analisar os pacotes durante a captura;

- pode ser executado em diversas plataformas como Windows, GNU/Linux, Mac OS X, Solaris entre outros;

- possui uma boa quantidade de ferramentas para análise de dados de voz sobre IP;

- lê e escreve os dados capturados em diversos formatos de arquivos que podem ser utilizados em outros programas similares;

- grava múltiplos arquivos de acordo com o tamanho ou tempo decorrido da captura;

- possui filtros de captura e exibição de pacotes de acordo com endereços IP, portas ou tipos de protocolos.

A seguir, algumas características importantes desse aplicativo serão detalhadas, no que se refere ao tratamento e análise de pacotes relacionados a VolP. As características citadas levam em conta somente os protocolos SIP e RTP.

\subsubsection{Análise dos campos de mensagens}

Todas as mensagens podem ser analisadas de uma forma mais profunda, permitindo visualizar cada campo e seus parâmetros de forma clara. Essa característica permite que o usuário copie para a área de trabalho partes específicas das mensagens, além de poder criar filtros para exibir mensagens que pertençam à mesma transação. 


\subsubsection{Visualização das transações de chamada}

Com o recurso da visualização das chamadas, é possível verificar de forma resumida todas as transações de chamada que ocorreram, dando uma visão mais ampla das ligações que aconteceram durante o período de captura.

Nessa tela, é possível ter as seguintes informações:

- Usuário origem e destino da chamada;

- endereço de origem da chamada;

- número de pacotes que a transação possui;

- qual o estado em que a transação ficou após a última mensagem capturada.

\subsubsection{Gráfico de transações de chamada}

Recurso que permite a visualização de todas as mensagens de uma transação de chamada de forma gráfica, semelhante ao que foi mostrado na Figura 6.

Ainda, ao clicar em cada seta que corresponde a uma mensagem SIP ou RTP da chamada, o Wireshark irá procurar a mensagem na lista de pacotes capturados e exibir seus campos.

É possível exibir mais de uma transação ao mesmo tempo através desse gráfico, fazendo seleções múltiplas na lista de exibição. Com esse recurso, o usuário pode analisar transações de chamada diferentes, mas que têm uma relação comum, por exemplo, uma chamada entre dois elementos IP num sistema de telefonia.

\subsubsection{Reprodutor de áudio de chamadas}

Caso a chamada tenha se estabelecido com o codificador G.711 [ITU72], o Wireshark consegue reproduzir o áudio da conversação ocorrida durante a ligação. Outros codificadores não são suportados pelo aplicativo.

O áudio é reproduzido de acordo com os dados que foram capturados, podendo levar em consideração o parâmetro de jitter buffer, que pode ser configurado no aplicativo para que ele descarte pacotes com valores de jitter superiores ao determinado pelo usuário. Essa facilidade faz com que o áudio reproduzido seja mais próximo ao que o usuário ouviu realmente, já que o aplicativo irá descartar pacotes da mesma forma que o equipamento receptor faria.

Ainda dentro da parte de reprodução do áudio, é possível visualizar um gráfico com a forma de onda do áudio contido nos pacotes. Além disso, o usuário pode perceber onde houve momentos de silêncio, bem como pontos de perda de pacotes, que são ressaltados pelo Wireshark através de trechos vermelhos na forma de onda. 
Para chamadas com outros codificadores, pode-se utilizar a facilidade do Wireshark de extração do payload dos pacotes RTP para serem salvos em arquivo. Essa informação pode ser convertida, através de outros aplicativos, para arquivos de áudio com formatos reconhecidos por tocadores padrões.

\subsubsection{Análise de pacotes RTP}

Com a análise de pacotes é possível examinar os seguintes parâmetros:

- Número de pacotes transmitidos e/ou recebidos;

- porcentagem de perda de pacotes;

- tempo máximo entre pacotes consecutivos;

- jitter;

- erros de sequência.

Apesar de o Wireshark possuir poucas funcionalidades para análise de pacotes de VolP, ele tem um importante papel no mundo de análise de redes de computadores e de telefonia IP.

O objetivo deste trabalho é desenvolver uma ferramenta que implemente todas as características listadas acima, no que se refere ao tratamento de pacotes SIP e RTP, porém com outras características essenciais para um profissional que trabalhe com VoIP. Essas outras características serão listadas no Capítulo 4.

\subsection{Cace Pilot}

O Cace Pilot [CACE] é um aplicativo comercial com foco maior para análise de desempenho de redes, com alguns recursos interessantes para o mundo de VolP. Ele foi feito pelo mesma empresa desenvolvedora do Wireshark.

Esse aplicativo tem objetivos bem diferentes do Wireshark, já que está mais voltado a apresentar resultados relativos ao consumo de rede, qualidade nas chamadas, número de sucessos e insucessos das transações, além de relatórios indicando máquinas com maior utilização e tráfego de VoIP.

A seguir, uma lista resumida das características principais referentes à análise de pacotes de VolP:

- Lista com as ligações bem-sucedidas e motivos de insucesso;

- consumo de banda de rede através de gráficos;

- lista com as chamadas e parâmetros como perda de pacotes, jitter, qualidade de cada chamada;

- gráficos que mostram o tráfego de pacotes de VolP para cada máquina;

- gráficos com número de ligações por máquina ou usuário;

- relatórios detalhados em diversos formatos de arquivos. 
Como é um aplicativo com grandes recursos para análise de tráfego de vários outros protocolos, ele possui facilidades interessantes para isolar pontos ou chamadas específicas. Essa análise isolada permite verificar uma possível causa de problemas, como ligações com baixa qualidade, fazendo uma checagem para verificar como está o tráfego de pacotes de outros protocolos no momento exato em que ocorreu o problema.

Apesar de muito poderoso, o Cace Pilot não é um aplicativo no qual é possível trabalhar de forma isolada, pois quando se torna necessário analisar os campos dos pacotes ou inteirar-se da sequência de mensagens, é necessário lançar mão do Wireshark.

Uma grande vantagem do Cace Pilot é permitir a o exame mais rápido de arquivos de captura muito grandes, da ordem de centenas de megabytes. Isso é possível já que esse aplicativo possui mecanismos de análise mais eficientes em computadores multicore.

Pode-se dizer que as demais características do Cace Pilot são supridas pelo Wireshark. Caso o usuário ainda necessite de ferramentas de observação mais profunda em mensagens, campos, temporizações entre mensagens e visualizador de transações SIP, esse deve ainda utilizar o Wireshark. O Cace Pilot é mais voltado para análise do serviço e sua qualidade do que profundidade de problemas em nível de protocolo.

\subsection{SIP Automatic Debugger}

O SIP Automatic Debugger [BAO09] é uma ferramenta desenvolvida em C para ambiente Windows e é composta por três módulos que operam em sequência, como descrito nos itens abaixo:

- Sniffer: desenvolvido utilizando a biblioteca WinpCap, é responsável por capturar os pacotes da rede e selecionar os pacotes SIP dentre os capturados.

- Analisador: classifica as mensagens SIP baseando-se nas transações e diálogos que ocorrem durante o processo de captura.

- Controlador: responsável por verificar o fluxo de mensagens por comparação com um conjunto de regras previamente carregado no aplicativo.

O princípio desse aplicativo é analisar cenários, comparando comportamentos conhecidos de equipamentos. Nesse caso, os cenários de testes devem ser carregados previamente, podendo então verificar se algo está fora do comportamento esperando, como ausência de campos nas mensagens SIP ou temporizações incorretas.

Além disso, ele foi desenvolvido para testar e avaliar a interoperabilidade entre equipamentos, determinando fontes de incompatibilidades, identificando falhas e preparando um roteiro para resolução de problemas. 


\section{$4 \quad$ VolPFix}

O projeto do VolPFix surgiu da necessidade de uma ferramenta que complementasse as demais existentes no ramo de análise de rede de computadores e telefonia IP. Profissionais que trabalham nesse mercado podem possuir conhecimento limitado das tecnologias e protocolos dos equipamentos de VolP, pois é algo muito específico desse tipo de tecnologia.

Aplicativos como o Wireshark e o Cace Pilot foram desenvolvidos com objetivos mais amplos, cobrindo uma gama maior de protocolos e aplicações de redes de computadores. As ferramentas de VolP nesses programas fazem parte de um conjunto de funcionalidades maior, não sendo o objeto alvo de sua utilização.

O Wireshark poderia ter sido utilizado como base no desenvolvimento desse trabalho, sendo alterado para a criação de novas funcionalidades. Essa decisão não foi tomada, pois ele foi construído para trabalhar com apenas um thread, mesmo em sistemas multicore. Além disso, para que ele se tornasse uma ferramenta eficiente, como é o VolPFix, mudanças mais drásticas teriam que ser feitas como, por exemplo, a substituição do interpretador de mensagens SIP. Fatores como esses fizeram optar por não utilizá-lo.

O VolPFix foi construído com propósito único de ser uma ferramenta de gerenciamento exclusiva para VoIP, possuindo somente as funcionalidades necessárias para dar suporte ao usuário a observar e diagnosticar problemas de telefonia IP.

As ferramentas do VolPFix foram elaboradas para guiar o usuário a realizar a análise partindo de uma visão macro das ocorrências, passando por funcionalidades que trazem informações, relatórios e estatísticas, até chegar aos pacotes que compõem uma determinada transação. Essa abordagem permite que os usuários de pouca experiência utilizem a ferramenta até o nível adequado do seu conhecimento, não deixando os usuários avançados sem as ferramentas de análise mais profundas.

Ele possui as seguintes características principais:

- Captura e análise eficiente de mensagens de sinalização SIP e pacotes RTP de áudio;

- exibição de relatórios com diagnósticos de ocorrências das transações de registro e chamadas que foram capturadas;

- identificação dos problemas mais comuns que ocorrem num sistema de telefonia IP relativos à sinalização e ao fluxo de mídia.

Os usuários dessa ferramenta podem ser:

- profissionais do ramo de telefonia, que possuem bons conhecimentos dessa atividade, mas não possuem total domínio de redes de computadores;

- analistas de redes de computadores, que possuem a formação necessária para tal atividade, mas não têm experiência em telefonia convencional e IP; 
- profissionais que trabalham em empresas prestadoras de telefonia IP, para monitoração e acompanhamento dos serviços oferecidos;

- instaladores de equipamentos de VolP, pois a ferramenta possui uma interface simplificada para esse tipo de profissional.

O local de sua instalação depende das necessidades do usuário, mas na maioria dos casos é ideal que ele seja colocado junto ao PBX IP ou aos terminais SIP de interesse. Isso pode ser feito configurando os elementos de rede, como switches a espelharem as portas desses equipamentos para o VolPFix.

A essência do VolPFix é permitir que usuários que não tenham conhecimento detalhado em protocolos de sinalização e mídia possam analisar, identificar e apontar possíveis problemas em uma rede com serviço de VoIP. Porém, ainda oferecerá facilidades para exame profundo das mensagens SIP e RTP, assim como é feito com o Wireshark, já que nem todos os problemas poderão ser identificados automaticamente pelo VolPFix, ficando, ainda, a cargo do usuário analista, interpretar os dados de um problema mais complexo.

\subsection{Arquitetura}

Nesta seção será descrita a arquitetura do VoIPFix, estudando os principais módulos da implementação do aplicativo. Os detalhes de implementação de cada módulo e de cada funcionalidade serão descritos na Seção 4.4.

O VolPFix foi construído com o conceito de programação orientada a objetos, utilizando a linguagem $\mathrm{C}++$. Ele é composto por 25 classes contendo 9542 linhas de código espalhadas por 49 arquivos. VolPFix.

A Figura 8 mostra os módulos principais da arquitetura de construção do 


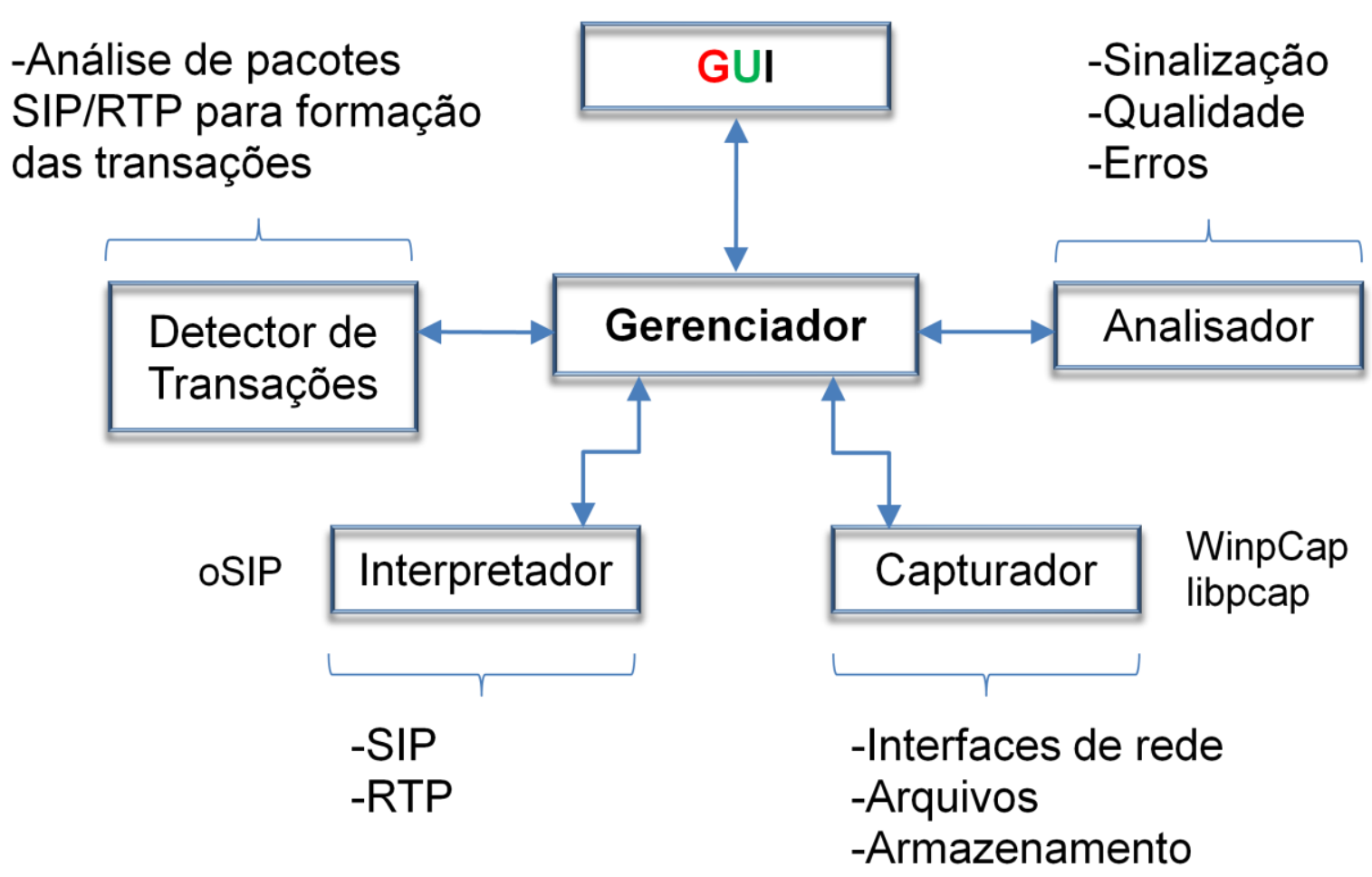

Figura 8 - Arquitetura do VolPFix.

\subsubsection{Capturador}

Este módulo é responsável pela coleta de pacotes, seja ela feita através de uma interface de rede ou por arquivos salvos em disco, e também pelo salvamento de pacotes em arquivos. Essas duas tarefas são implementadas através de bibliotecas específicas para esse tipo de aplicação: WinpCap, para ambiente Windows, e libpcap, para ambiente GNU/Linux.

As tarefas executadas por esse módulo são:

- Listagem das interfaces de rede do sistema, para que possam ser exibidas pela interface gráfica, permitindo que o usuário escolha a mais adequada;

- recebimento de instrução de abertura de uma interface de rede e captura dos pacotes através dela;

- captura de pacotes através de uma interface de rede, que pode ser feita em modo promíscuo, ou seja, captura todos os pacotes que passarem fisicamente pela interface de rede selecionada, mesmo que não tenham como destino essa interface;

- aplicação dos filtros escolhidos pelo usuário para capturar somente pacotes de interesse (endereço IP, porta, etc.);

- recebimento de instrução para abertura de arquivos salvos em disco;

- salvamento de listas de pacotes em disco, mediante instrução da interface gráfica de usuário; 
- aviso ao módulo de hierarquia superior sobre a chegada de um novo pacote em uma interface de rede ou de um arquivo aberto, dependo do que foi instruído para ser feito.

Essas tarefas compõem a base da aplicação, no que diz respeito à coleta das informações necessárias para o funcionamento do VolPFix.

O módulo Capturador contém particularidades em relação ao sistema operacional que está sendo utilizado, já que está em contato com bibliotecas diferentes para cada ambiente. Porém, a forma de utilização das bibliotecas de captura é bem semelhante, não tendo nenhum impacto no desempenho ou perda de funcionalidade de um sistema para o outro.

A interface de interação desse módulo com os de hierarquia superior fazem com que ele seja visto de forma independente do tipo de sistema operacional utilizado.

O Capturador possui apenas uma thread de execução, pois não é possível abrir um arquivo utilizando tarefas concorrentes, visando a economia de tempo, como é feito em outros módulos do VolPFix.

Quando os dados estão sendo capturados através de uma interface de rede, os pacotes são armazenados em memória e não em arquivos temporários em disco.

\subsubsection{Interpretador}

Como o próprio nome diz, neste módulo os pacotes provenientes de uma interface de rede ou de um arquivo aberto do disco são selecionados e interpretados, visando extrair somente as informações de interesse para os demais módulos da hierarquia superior da aplicação.

A forma de trabalho do Interpretador depende do comportamento do resto do sistema, que pode estar sendo utilizado para capturar pacotes de uma interface de rede ou comandado a abrir um ou mais arquivos do disco. Porém, independentemente do modo de trabalho, ele irá executar os seguintes procedimentos quando um pacote é recebido:

- Análise do cabeçalho Ethernet da camada de enlace e verificação se o protocolo utilizado na camada de rede do pacote é o IP. Isso deve ser feito, pois todos os pacotes de voz sobre IP utilizam esse protocolo como camada de rede;

- verificação do cabeçalho IP, se o protocolo de transporte utilizado é o UDP, pois, como dito, o VolPFix somente analisa pacotes sobre esse protocolo de transporte;

- coleta das informações de endereço IP e porta de origem e destino desse pacote, pois a informação será essencial aos módulos de análise de transações; 
- verificação se os dados transportados pelo pacote no payload UDP pertence a um pacote SIP. Isso é feito analisando a primeira linha do texto, em busca de palavras chaves e combinações características de um pacote SIP. O passo economiza processamento, pois elimina pacotes previamente marcados como não SIP do passo de interpretação propriamente dito;

- envio de um pacote SIP ao processo de interpretação, o que transforma o texto da mensagem em uma estrutura padrão, podendo ser analisada de forma mais eficiente pelos módulos de análise. Esse processo de interpretação é realizado pela biblioteca oSIP. Caso o pacote não seja SIP, ainda há a possibilidade dele ser RTP, que não é um protocolo que carrega mensagens em formato texto. Nesse caso, não é possível ter certeza absoluta se um pacote é ou não RTP, mas alguns testes são feitos a fim de verificar a sua integridade e marcá-lo. Os demais pacotes, que não foram marcados como SIP nem RTP, são descartados para não ocuparem espaço em memória.

Quando o VolPFix está sendo utilizado para abrir arquivos salvos em um disco, esse módulo executa o procedimento descrito acima em múltiplas tarefas concorrentes, visando a economia de tempo de processamento e o total aproveitamento dos recursos da máquina hospedeira.

\subsubsection{Detector de transações}

Módulo responsável por identificar os pacotes SIP e RTP de uma mesma transação, para que possa ser feita análise de estados de fechamento, cálculos e estatísticas pelo módulo analisador. Essa tarefa é executada quando o VolPFix recebe pacotes de uma interface de rede e quando recebe pacotes de um arquivo sendo aberto do disco.

A tarefa de agrupar os pacotes SIP e RTP de uma mesma transação revelou as vantagens do VolPFix em relação ao Wireshark, no que diz respeito à eficiência de análise, facilidade ao usuário do aplicativo, além de facilidade estrutural para 0 crescimento de novas funcionalidades ao VolPFix.

As funcionalidades de exibição de gráfico das transações e exibição de pacotes utilizam as informações geradas por esse módulo, uma vez que elas necessitam justamente que os pacotes de uma mesma transação estejam agrupados de forma organizada.

Da mesma forma como é feito no módulo interpretador, o VolPFix realiza o trabalho nesse módulo com vários threads concorrentes, ao abrir arquivos salvos em disco, com o objetivo de economizar tempo de processamento. 


\subsubsection{Analisador}

O módulo analisador realiza as tarefas de maior interesse ao usuário, como por exemplo:

- Identificação de problemas de sinalização;

- identificação de problemas de fluxo de mídia;

- cálculos de perda de pacotes, jitter e erros de sequência em fluxos de mídia;

- geração de gráficos de estatísticas, como fechamento de chamadas.

O analisador não utiliza vários threads concorrentes para realizar o trabalho descrito acima, já que isso deve ser feito de forma sequencial para cada transação a ser analisada. O ganho de tempo com utilização de tarefas concorrentes não seria significativo nesse caso, além de trazer uma grande dificuldade na sua implementação.

\subsubsection{GUI}

A interface gráfica de usuário (GUI) foi desenvolvida de modo a atingir os seguintes objetivos principais:

- Proporcionar a usuários com menos experiência em protocolos de VolP, facilidades que não são encontradas em outras aplicações do mesmo tipo;

- ter um caminho de utilização de modo que as telas com informações mais ricas em conteúdo, e também mais complexas, sejam acionadas sob instrução do usuário, caso esse necessite;

- tornar a utilização mais eficiente e rápida, sem exibir grande quantidade de informação nos primeiros momentos da abertura de arquivos em disco. As telas que trazem grande quantidade de pacotes só são exibidas se o usuário assim necessitar;

- ter poucos controles, mas com funcionalidades específicas e eficientes, sem necessitar de muitos ajustes ou configurações por parte dos usuários;

- exibir relatórios e estatísticas de forma clara e concisa, trazendo apenas informações básicas que o usuário deseja. Informações mais avançadas só aparecem sob instrução do usuário.

Apesar de os objetivos acima citados terem sido atingidos na primeira versão do VolPFix, muitas facilidades deverão ser adicionadas ao aplicativo, de modo a torná-lo ainda mais amigável e eficiente, tanto para usuários leigos como para usuários avançados. A seção de trabalhos futuros trata de ideias de aperfeiçoamento para a aplicação.

A Figura 9 mostra a interface gráfica do VolPFix com as janelas principais abertas. 


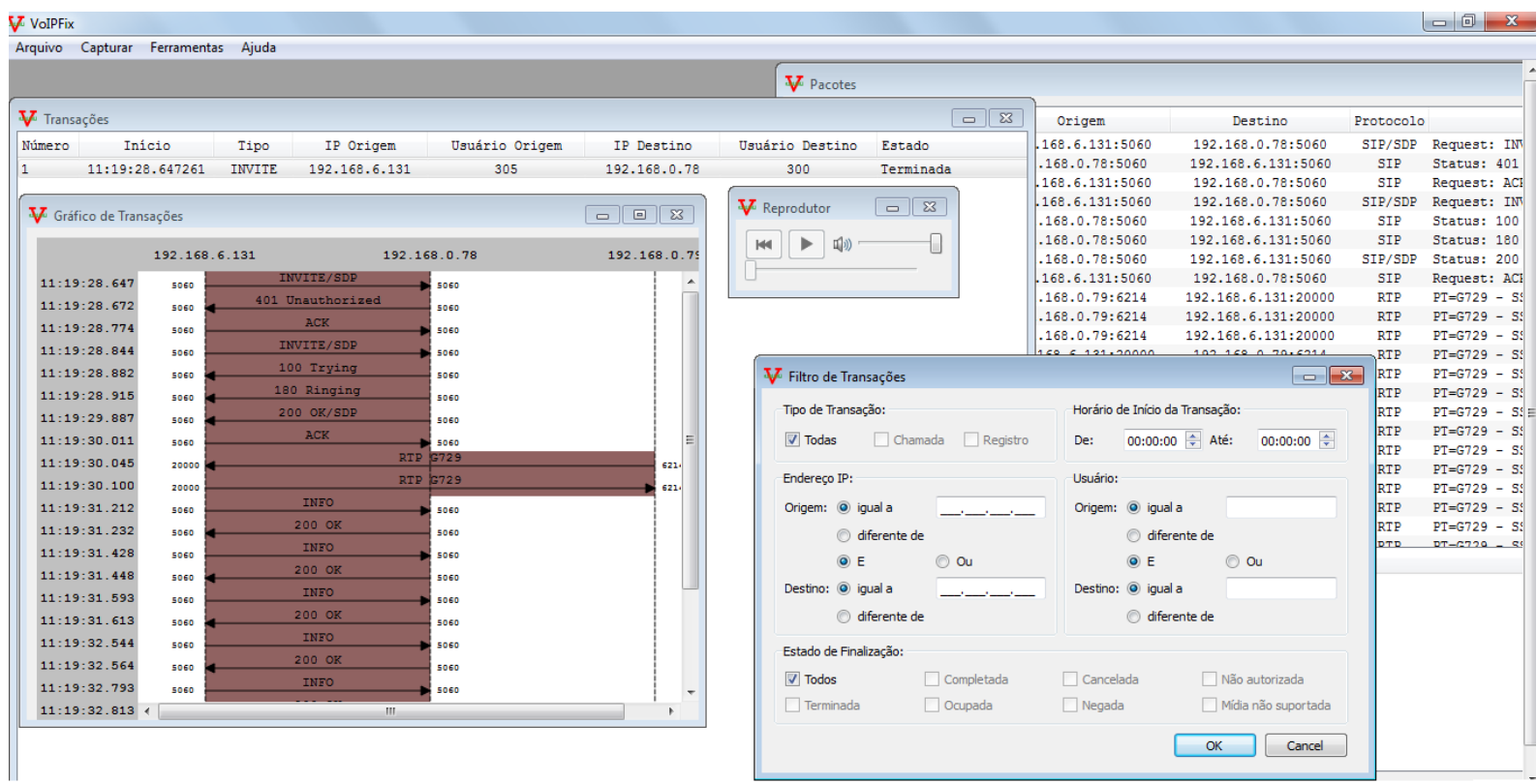

Figura 9 - Interface gráfica do VolPFix.

\subsubsection{Gerenciador}

O gerenciador, como o próprio nome diz, cuida do controle de todo o funcionamento da aplicação. Algumas de suas funções são:

- Tratar os comandos enviados pelo usuário através da interface gráfica até os módulos responsáveis por executá-los;

- armazenar as configurações do sistema realizadas pelo usuário;

- direcionar o fluxo de pacotes do capturador até o analisador, quando necessário;

- direcionar as transações de interesse do módulo de transações até o módulo analisador;

- gerenciar a forma de utilização da aplicação (captura de pacotes através de uma interface de rede ou abertura de arquivos salvos em disco).

Esse módulo funciona como um maestro da aplicação inteira, cuidando ainda da abertura de janelas de forma automática na interface gráfica de usuário e também no gerenciamento dos objetos utilizados por elas.

\subsection{Funcionalidades}

O VolPFix foi construído com o objetivo de ser uma ferramenta de análise de telefonia IP, com recursos específicos para esse tipo de aplicação de redes de computadores. A premissa inicial era se tornar totalmente capaz de ser utilizado como ferramenta única de avaliação e investigação de protocolos de sinalização e transporte de mídia, sem a necessidade de outras aplicações. Por esses motivos, 
algumas de suas funcionalidades formam a base para que ele seja autocontido e ofereça recursos necessários para o funcionamento de características inovadoras e eficientes em relação a outras ferramentas desse tipo.

A seguir, o detalhamento de cada uma das funcionalidades do VolPFix, partindo das características de base, até as mais sofisticadas e inovadoras. A descrição traz o motivo de sua existência dentro da aplicação e o que ela realmente faz.

\subsubsection{Captura de pacotes}

a) Necessidade:

Para que o VolPFix não dependa de outros aplicativos para realizar a captura de pacotes, que, dentre outros motivos, necessitaria de instalação, configuração e operação de dois programas diferentes, essa funcionalidade foi implementada na ferramenta. Além disso, muitas funções são executadas durante o processo de captura, oferecendo informações de análise em tempo de captura.

b) Funcionamento:

O VolPFix realiza a captura de todos os pacotes de uma determinada interface de rede, permitindo o salvamento em arquivos, que poderão ser abertos para uma análise posterior pelo usuário. A captura ainda pode ser parametrizada para filtrar os pacotes, segundo informações como:

- Endereço IP de origem ou destino;

- protocolo de transporte;

- endereço MAC de origem ou destino.

Ele realiza a captura dos pacotes em modo "promíscuo", ou seja, são capturados todos os pacotes que passam pela interface de rede escolhida, mesmo que o pacote não tenha como destino essa interface de rede.

Na barra de menus da aplicação, o item "Captura" permite iniciar ou parar um processo de captura. A opção "Iniciar" mostra a tela da Figura 10.

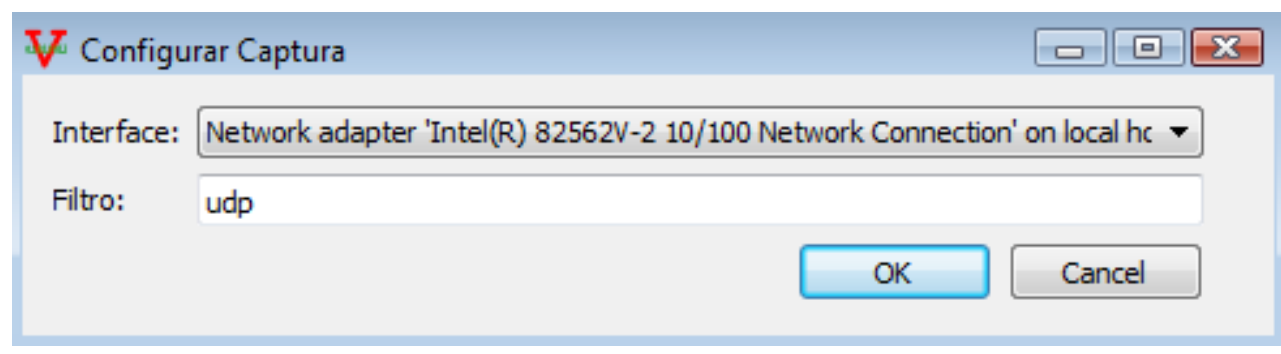

Figura 10 - Tela para iniciar captura de pacotes. 
Os componentes dessa tela são:

- Interface: lista as interfaces de rede disponíveis no sistema, para que o usuário selecione qual deseja capturar os pacotes.

- Filtro: permite especificar o filtro de pacotes, através da sintaxe utilizada pela biblioteca de captura, a ser utilizado durante o processo de captura.

\subsubsection{Análise de pacotes de forma eficiente em plataformas multicore}

a) Necessidade:

A análise de arquivos de captura muito extensos, da ordem de algumas dezenas de megabytes, normalmente é lenta, devido ao grande número de pacotes capturados. Isso acontece quando a coleta dos dados foi feita em uma rede de grande fluxo ou foi realizada durante um intervalo de tempo muito longo.

O VoIPFix foi concebido para ser uma ferramenta eficiente de análise. Como atualmente a maioria dos computadores possuem processadores multicore, a ferramenta foi construída para aproveitar ao máximo o poder de processamento desses sistemas.

Nos testes de desempenho, mostrados na Seção $4.5 \quad$ Testes de , fica claro o ganho de eficiência do VolPFix em relação a outras ferramentas, na abertura e análise de arquivos grandes.

b) Funcionamento:

Em plataformas com processador multicore, o VolPFix tem o desempenho de processamento dos pacotes aumentado, utilizando-se dessa característica para realizar a análise em mais de uma tarefa paralelamente.

Certas funcionalidades, como interpretar os pacotes de VOIP para montagem das informações das transações, podem ser executadas em mais de uma thread ao mesmo tempo dentro do programa. Isso traz um ganho de desempenho considerável para o VolPFix.

O VolPFix está preparado para plataformas multicore e, por isso, terá um desempenho maior do que o Wireshark, que, mesmo em plataformas com mais de um núcleo, acaba utilizando somente um para realizar o processamento dos pacotes [WIRb].

Quando o usuário abre um arquivo capturado, que contém um tamanho acima de algumas unidades de MBytes, ele pode perceber o trabalho do VolPFix, sendo realizado em mais de uma thread, como mostra a Figura 11. 


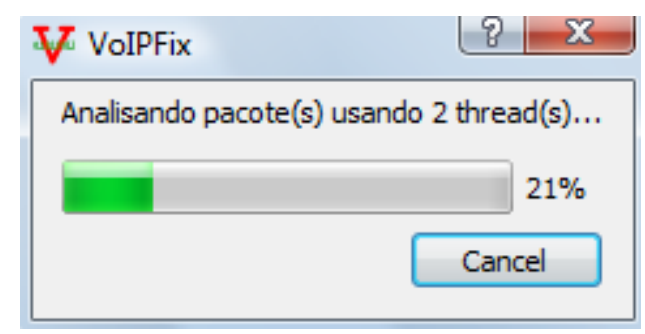

Figura 11 - Analisando pacotes em mais de um thread.

O número de threads é mostrado nessa tela apenas com intuito informativo, indicando quantas tarefas concorrentes estão sendo executadas para tratar o arquivo que está sendo aberto. Esse número representa a quantidade de núcleos do processador disponíveis do sistema.

\subsubsection{Análise durante o processo de captura}

a) Necessidade:

Em certos casos, o usuário necessita capturar os dados e, ao mesmo tempo, salvá-los em arquivos, mas também deseja realizar a análise de algumas situações ou problemas que esteja interessado em detectar durante esse processo. Para isso o aplicativo realiza a interpretação dos pacotes durante a captura.

b) Funcionamento:

O VolPFix permite que os pacotes sejam analisados durante o processo de captura, e, assim, realizar muitas tarefas paralelamente à captura. Essa característica é importante para situações em que é necessário identificar uma situação desejada pelo usuário em tempo real, sem a necessidade de salvar em um arquivo para uma análise posterior.

Todas as ferramentas do VolPFix podem ser executadas durante o processo de captura, com base nos pacotes capturados até o momento da utilização de cada funcionalidade. Porém, até o momento da escrita deste trabalho, somente a tela que lista as transações é atualizada durante a captura. Será proposto um mecanismo que atualiza as demais telas durante esse processo, sem que haja a necessidade de fechar e reabrir as telas correspondentes, como acontece com no Wireshark.

\subsubsection{Análise de múltiplos arquivos gravados sequencialmente}

a) Necessidade:

Para que não sejam gerados arquivos muito extensos, muitos aplicativos de captura são configurados para salvar os dados em vários arquivos gravados sequencialmente. Isso traz o benefício de não tornar o processo de análise muito 
lento, uma vez que o tamanho do arquivo pode ser controlado de tal forma a somente ter dimensões apropriadas para a máquina de análise. Porém, isso traz algumas dificuldades para o usuário, como, por exemplo, a existência de transações que começam em um arquivo e só são finalizadas no arquivo gravado na sequência. Atualmente, as ferramentas de captura possuem uma funcionalidade que permite mesclar dois ou mais arquivos, porém, isso torna a análise ainda mais lenta, já que essa função gera um arquivo ainda maior.

\section{b) Funcionamento:}

Com o VolPFix, o usuário pode escolher a opção de abrir arquivos gravados sequencialmente, através do menu "Arquivo - Abrir Sequencial". O comando, faz a ferramenta abrir todos os arquivos selecionados de uma só vez, dando a sensação ao usuário de que ele está abrindo somente um arquivo contendo todas as informações. Não é feito nenhum processo de mescla, nem a geração de um arquivo temporário contendo os demais.

Obviamente, o tempo de processamento do conjunto de arquivos é proporcional ao tamanho dos dados, porém, não acontecem os problemas gerados pelo processo de salvamento de arquivo de forma sequencial. Além disso, o usuário pode realizar a análise, sem ter o problema de encontrar parte de uma transação em outro arquivo e ter de repetir o processo inteiro novamente.

Todas as ferramentas do VolPFix funcionam normalmente para esse tipo de situação.

\subsubsection{Exibição de lista de transações}

a) Necessidade:

Para usuários com menor conhecimento sobre os protocolos, é difícil realizar análises e localizar as transações olhando para vários pacotes em uma lista. É necessário que a ferramenta agrupe essas mensagens de acordo com as transações às quais elas pertençam.

b) Funcionamento:

No VolPFix, quando o usuário abre um arquivo ou inicia uma captura, a primeira tela que aparece é a lista de transações. Dessa forma ele começa a realizar a análise partindo das transações SIP que possui, e não a partir de uma lista de pacotes, que muitas das vezes confunde até mesmo usuários experientes.

A Figura 12 mostra o resultado da abertura de um arquivo qualquer, que contém várias transações. 


\begin{tabular}{|c|c|c|c|c|c|c|c|}
\hline \multicolumn{8}{|c|}{$\forall$ Transações } \\
\hline Número & Início & Tipo & IP Origem & Usuário Origem & IP Destino & Usuário Destino & Estado \\
\hline 1 & $09: 49: 17.544490$ & REGISTER & 192.168 .0 .218 & 760 & $192.168 \cdot 0.220$ & 760 & Completada \\
\hline 2 & $09: 49: 18.534548$ & REGISTER & 192.168 .0 .218 & 751 & 192.168 .0 .220 & 751 & Completada \\
\hline 3 & $09: 49: 20.515661$ & REGISTER & 192.168 .0 .218 & 758 & 192.168 .0 .220 & 758 & Completada \\
\hline 4 & $09: 49: 47.697223$ & REGISTER & 192.168 .6 .131 & 305 & 192.168 .0 .78 & 305 & Completada \\
\hline 5 & $09: 49: 47.764227$ & REGISTER & 192.168 .6 .131 & 203 & 192.168 .0 .218 & 203 & Intervalo muito curto \\
\hline 6 & $09: 49: 47.838216$ & REGISTER & 192.168 .6 .131 & 100 & 192.168 .3 .80 & 100 & Completada \\
\hline 7 & $09: 49: 48.256248$ & REGISTER & 192.168 .6 .131 & 203 & 192.168 .0 .218 & 203 & Completada \\
\hline 8 & $09: 50: 04.624188$ & INVITE & 192.168 .6 .131 & 305 & 192.168 .0 .78 & 300 & Terminada \\
\hline 9 & $09: 50: 05.801246$ & REGISTER & 192.168 .3 .54 & 101 & 192.168 .3 .80 & 101 & Completada \\
\hline 10 & $09: 50: 06.293273$ & REGISTER & 192.168 .3 .54 & 564 & 192.168 .1 .1 & 564 & Completada \\
\hline 11 & $09: 50: 06.750318$ & REGISTER & 192.168 .3 .54 & 303 & 192.168 .0 .78 & 303 & Completada \\
\hline 12 & $09: 50: 36.136988$ & INVITE & 192.168 .6 .131 & 305 & 192.168 .0 .78 & 303 & Terminada \\
\hline 13 & $09: 50: 36.413010$ & INVITE & 192.168 .0 .78 & 305 & 192.168 .3 .54 & 303 & Terminada \\
\hline 14 & $09: 51: 01.502443$ & REGISTER & $192.168 \cdot 0.218$ & 757 & 192.168 .0 .220 & 757 & Completada \\
\hline 15 & $09: 51: 02.492501$ & REGISTER & $192.168 \cdot 0.218$ & 755 & $192.168 \cdot 0.220$ & 755 & Completada \\
\hline 16 & $09: 51: 03.483553$ & REGISTER & 192.168 .0 .218 & 756 & $192.168 \cdot 0.220$ & 756 & Completada \\
\hline 17 & $09: 51: 03.483555$ & INVITE & 192.168 .0 .78 & 301 & 192.168 .3 .54 & 303 & Terminada \\
\hline 18 & $09: 51: 07.443788$ & REGISTER & 192.168 .0 .218 & 763 & 192.168 .0 .220 & 763 & Completada \\
\hline 19 & $09: 51: 08.434844$ & REGISTER & 192.168 .0 .218 & 753 & 192.168 .0 .220 & 753 & Completada \\
\hline 20 & $09: 51: 11.405013$ & REGISTER & 192.168 .0 .218 & 750 & 192.168 .0 .220 & 750 & Completada \\
\hline 21 & $09: 51: 12.395065$ & REGISTER & 192.168 .0 .218 & 701 & 192.168 .0 .78 & 701 & Completada \\
\hline 22 & $09: 51: 12.402084$ & REGISTER & $192.168 \cdot 0.218$ & 700 & 192.168 .0 .78 & 700 & Completada \\
\hline 23 & $09: 51: 25.336810$ & INVITE & 192.168 .0 .78 & 300 & 192.168 .6 .131 & 305 & Terminada \\
\hline 24 & $09: 51: 35.164370$ & REGISTER & 192.168 .0 .218 & 759 & $192.168 \cdot 0.220$ & 759 & Completada \\
\hline 25 & $09: 51: 45.065940$ & REGISTER & 192.168 .0 .218 & 754 & $192.168 \cdot 0.220$ & 754 & Completada \\
\hline 26 & $09: 51: 46.055991$ & REGISTER & 192.168 .0 .218 & 762 & $192.168 \cdot 0.220$ & 762 & Completada \\
\hline 27 & $09: 51: 47.047053$ & REGISTER & 192.168 .0 .218 & 761 & $192.168 \cdot 0.220$ & 761 & Completada \\
\hline 28 & $09: 51: 51.008279$ & REGISTER & 192.168 .0 .218 & 752 & 192.168 .0 .220 & 752 & Completada \\
\hline
\end{tabular}

Figura 12 - Tela com a lista de transações.

As informações apresentadas nessa tela são:

- Número: indica o número da transação na lista;

- Início: hora de início. Esse é o tempo em que a máquina capturou o primeiro pacote da transação;

- Tipo: tipo da transação. As duas principais são REGISTER e INVITE, que respectivamente, indicam transação de registro e chamada;

- IP Origem: o endereço IP de origem do primeiro pacote. Normalmente é o endereço do UAC que solicitou a requisição ao UAS;

- Usuário Origem: usuário que originou a requisição ao UAS. No caso de um pedido de registro, esse é o usuário que irá se autenticar, enviando informações de localização;

- IP Destino: endereço IP destino do primeiro pacote. Geralmente é o endereço do UAS que recebe a requisição enviada pelo UAC;

- Usuário Destino: é o usuário alvo da requisição. Quando é um pedido de registro, o campo tem o mesmo valor do usuário de origem. Em se tratando de uma requisição de INVITE, é o usuário alvo da chamada;

- Estado: mostra o estado da requisição. Quando a tela representa as informações de um arquivo aberto, o campo mostra o estado da transação até o fim do arquivo, pois ela pode não ter sido capturada totalmente. Ainda, quando ela está sendo utilizada para captura de pacotes através de uma interface de rede, o campo é atualizado a cada mudança de estado da transação. 
Outras funções são acionadas a partir dessa tela, são elas:

- Exibição do gráfico de transações;

- lista de pacotes das transações;

- relatório com informações de perda de pacotes, jitter, erros de sequência, erros de sinalização e fluxo;

- tela para reprodução do áudio da chamada.

\subsubsection{Exibição de detalhes das mensagens de sinalização e voz}

a) Necessidade:

Para usuários com grandes conhecimentos de protocolos de VoIP, a utilização de aplicativos que não exibem detalhes das mensagens e seus campos é desagradável. Além disso, é previsto que nem todos os problemas serão diagnosticados pelo VolPFix num primeiro instante; dessa forma, qualquer usuário necessita de acesso fácil aos detalhes das mensagens de sinalização e voz.

\section{b) Funcionamento:}

O VolPFix, como o Wireshark, exibe todos os campos das mensagens de sinalização e voz de forma detalhada, pois, como é previsto, nem todos os problemas e situações serão cobertos por este trabalho, cabendo ao usuário utilizarse da facilidade para tentar identificar os problemas baseando-se no conteúdo dos pacotes de sinalização ou voz.

A facilidade é mais adequada para usuários, que tenham um conhecimento mais profundo dos protocolos de VolP. Porém, é interessante também para que usuários com pouco conhecimento possam aprender mais sobre a tecnologia e diagnosticar problemas mais complexos sem a ajuda do VolPFix, nos casos que não serão cobertos.

A Figura 13 mostra essa tela, que é chamada selecionando-se as transações de interesse na tela da lista de transações, clicando-se com o botão direito e escolhendo a opção "Pacotes". Quando mais de uma transação é selecionada, todos os pacotes serão exibidos na ordem em que eles foram capturados. Isso faz que os pacotes das transações fiquem misturados, o que é normal, já que pode existir mais de uma chamada ou registro acontecendo ao mesmo tempo. 


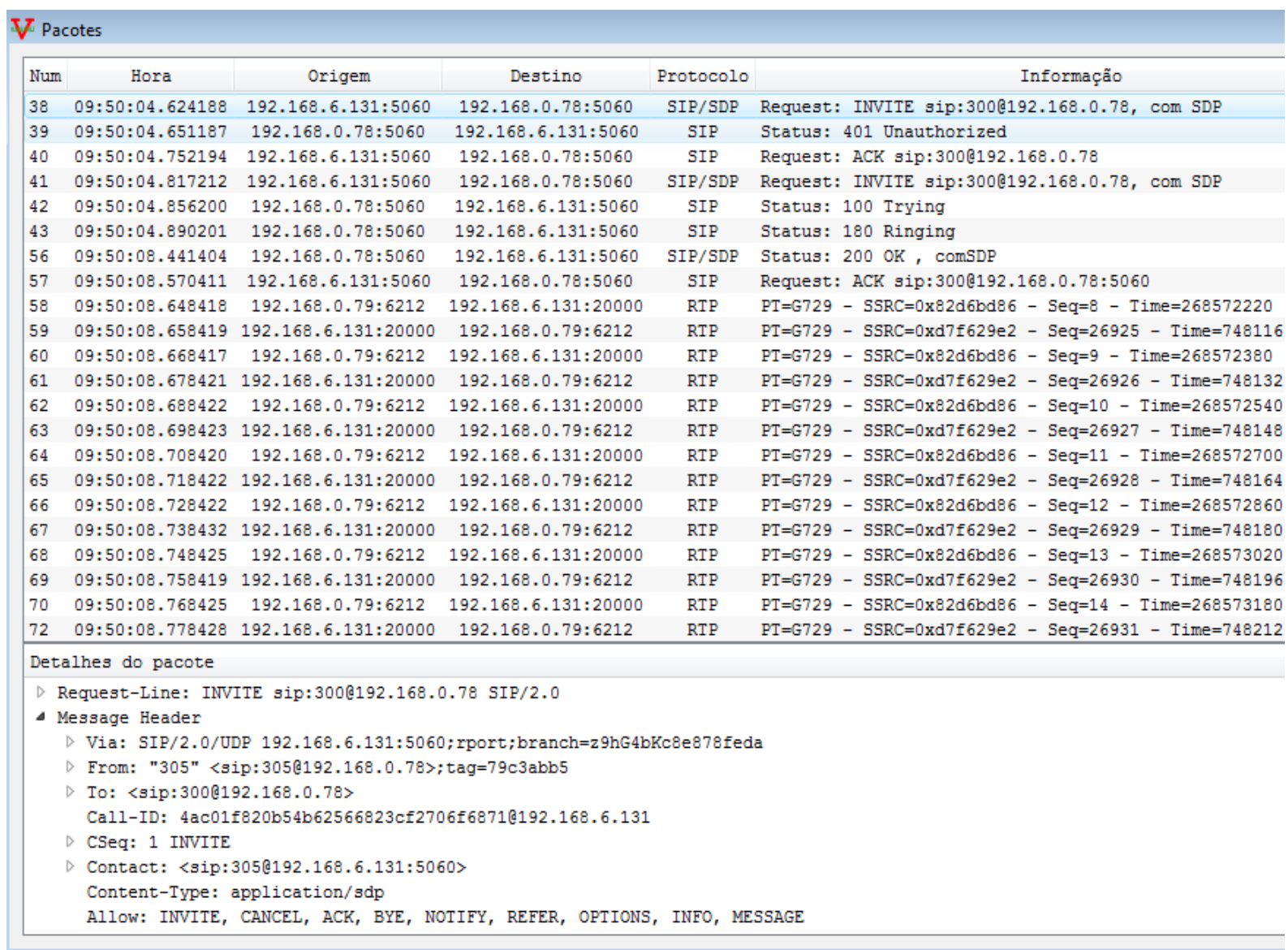

Figura 13 - Tela com detalhes dos pacotes.

Essa tela apresenta dois conjuntos de informação. O primeiro, que fica na parte superior, é a lista com todos os pacotes das transações selecionadas para exibição. Nessa parte, tem-se as seguintes informações:

- Num: mostra o número do pacote como referência em toda a lista;

- Hora: hora em que o pacote foi capturado pela interface de rede do sistema;

- Origem: endereço IP e porta de origem do pacote;

- Destino: endereço IP e porta de destino do pacote;

- Protocolo: o tipo do protocolo presente no pacote, que pode ser SIP, SIP/SDP (para mensagens SIP que contêm no corpo o protocolo SDP) ou RTP;

- Informação: campo que traz uma série de informações, dependendo do tipo do protocolo do pacote. Para mensagens SIP de requisição, a informação nesse campo é a linha de requisição. Para mensagens SIP de resposta, esse campo traz o código de resposta e a frase correspondente presente na mensagem. Quando for pacotes RTP, esse campo mostra um resumo do pacote, contendo o tipo do codificador de voz do pacote, SSRC, número de sequência e o timestamp do pacote.

A segunda parte dessa tela desmembra cada pacote selecionado na lista superior da tela, seja do protocolo SIP ou do RTP.

No exemplo mostrado na figura acima, um pacote SIP foi selecionado. Nesse caso, todos os campos do cabeçalho e do corpo, caso exista, são detalhados com seus valores. 


\subsubsection{Exibição de gráfico detalhado de transações}

a) Necessidade:

O agrupamento das mensagens SIP e RTP em uma lista de transações facilita muito o trabalho do usuário, porém é necessário uma forma gráfica de exibir essas requisições, para facilitar a localização e o entendimento do usuário.

b) Funcionamento:

Após o usuário exibir a lista de transações desejadas, ele pode selecionar uma ou mais transações para que elas possam ser exibidas em gráficos, da forma como mostrado nas figuras da Seção 2.4.

Com essa ferramenta, o usuário pode fazer uma análise em um nível mais elevado, podendo ainda clicar em uma mensagem específica e exibir seus campos e seus respectivos valores na tela com a lista de pacotes da transação.

Muitos dos problemas não apontados pelo VolPFix poderão ser descobertos por um usuário com bons conhecimentos de protocolos de VolP, através desse gráfico.

A Figura 14 é um exemplo dessa facilidade.

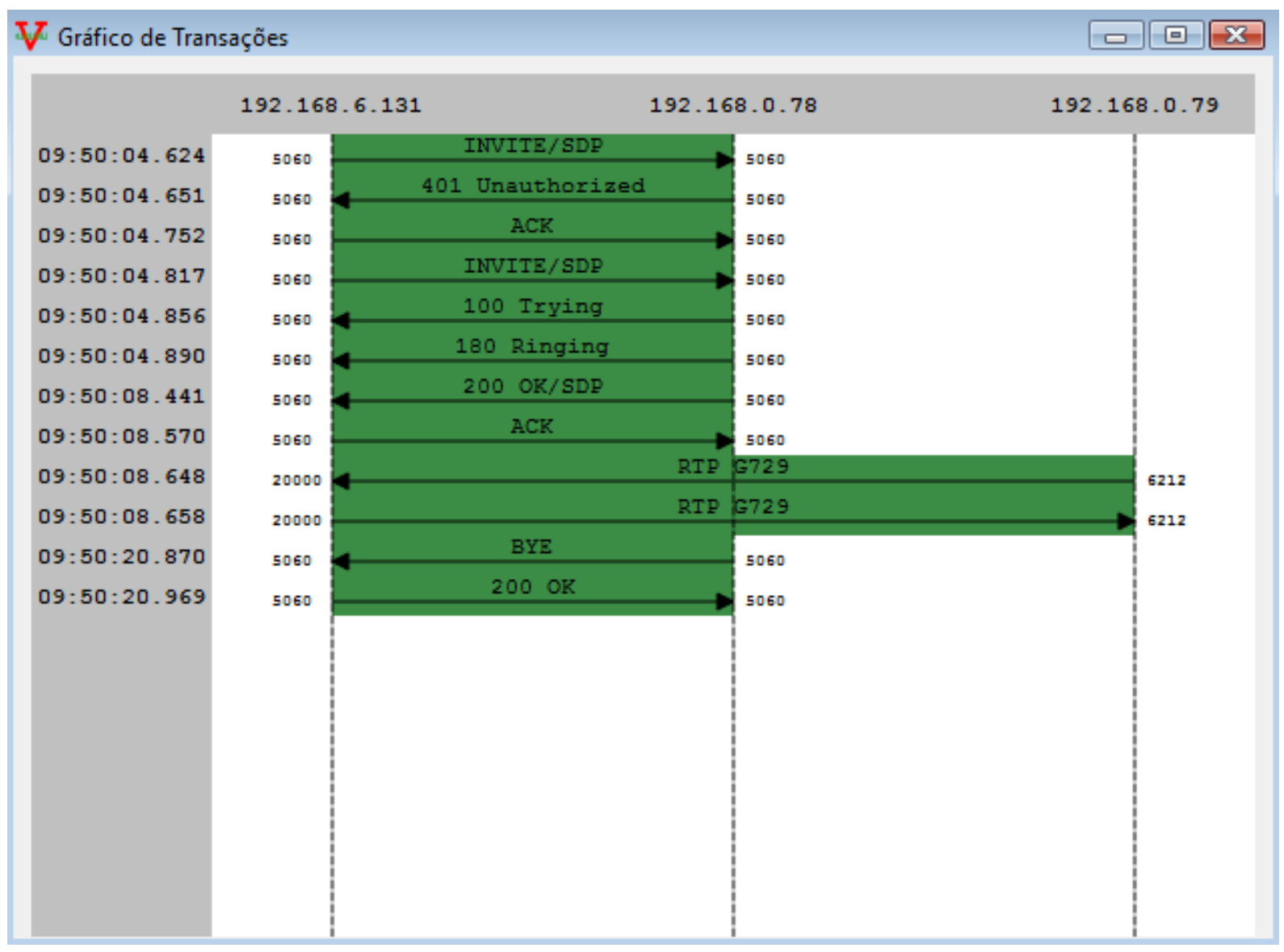

Figura 14 - Gráfico com transação de chamada. 
Essa tela contém informações completas sobre a troca de mensagens e fluxo de mídia entre os participantes da chamada. Com ela, o usuário pode identificar exatamente as máquinas participantes da transação, seus endereços IP, portas e tipo de codificador utilizado no fluxo de voz, que é representado apenas com uma seta no sentido em que ela acontece, já que são muitos pacotes.

No caso apresentado acima, o cliente que gera a requisição da chamada é o que possui o endereço IP 192.168.6.131 e o servidor que aceita o pedido é o que possui o endereço IP 192.168.0.78, que somente tratas as mensagens de sinalização. O dispositivo de rede com o endereço IP 192.168.0.79 é um media gateway responsável por tratar os pacotes de voz do servidor.

Ainda é possível observar de maneira mais amigável a troca de mensagens entre os participantes da transação, identificando a sequência de ocorrência dessas mensagens, os tempos entre cada uma delas, as mensagens de requisição e os códigos das mensagens de resposta.

Com esse gráfico e a tela de lista de pacotes abertas, clicando em qualquer mensagem SIP do gráfico, será marcado e exibido o pacote correspondente na tela de lista, permitindo ao usuário localizar rapidamente a informação de interesse. Quando clica-se na seta que corresponde ao fluxo RTP, será exibido o primeiro pacote desse fluxo detectado pela ferramenta. Essas duas telas associadas permitem que o usuário faça uma análise muito profunda sobre a transação desejada.

A Figura 15, mostra uma transação de registro. 


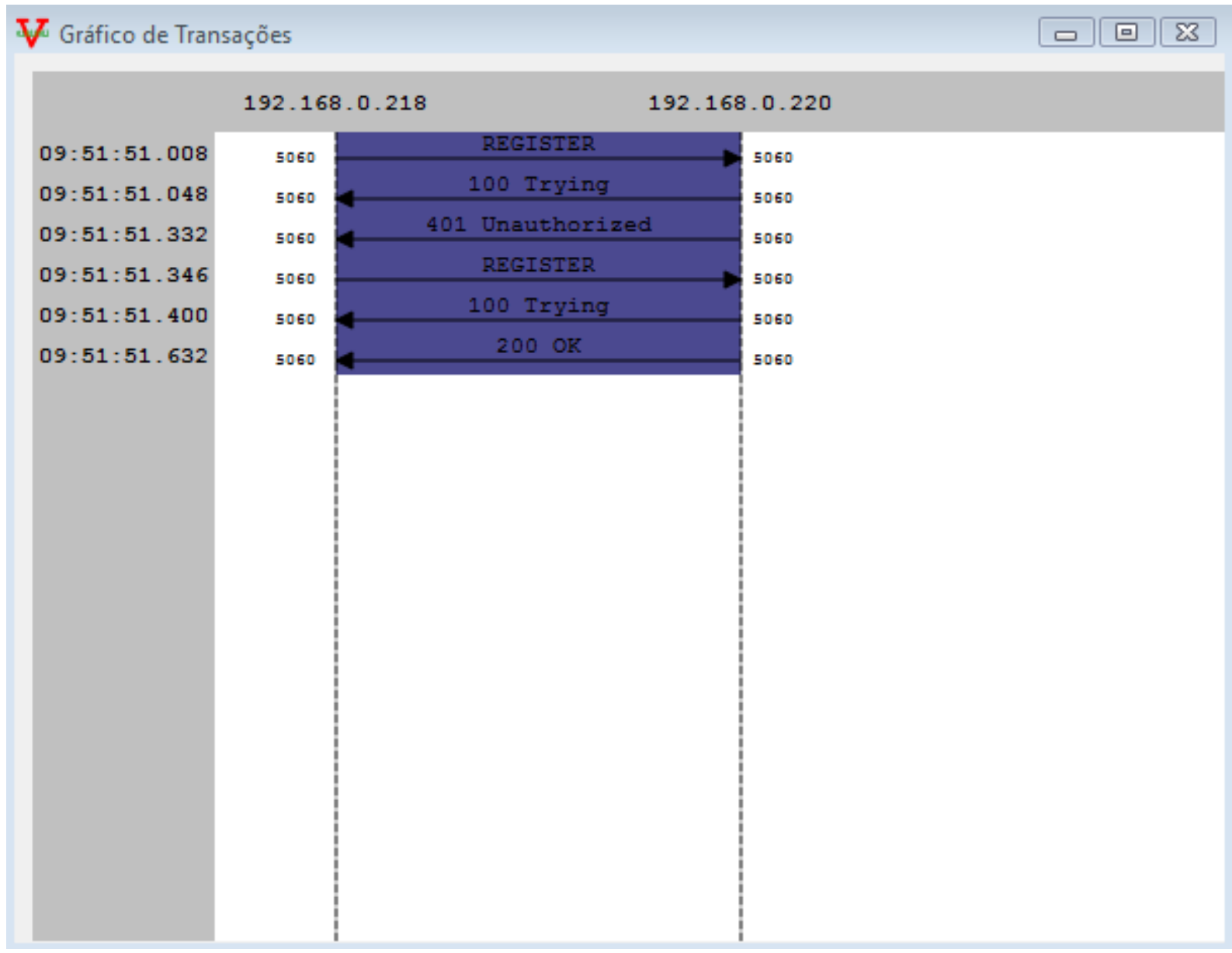

Figura 15 - Gráfico com transação de registro.

Essa tela é muito semelhante à tela de transação de chamada, e obviamente não possui setas com fluxo RTP. As informações nela contidas e seu comportamento são semelhantes ao descrito anteriormente.

A Figura 16 mostra duas transações ao mesmo tempo, a primeira, de registro e, a segunda, de chamada. 


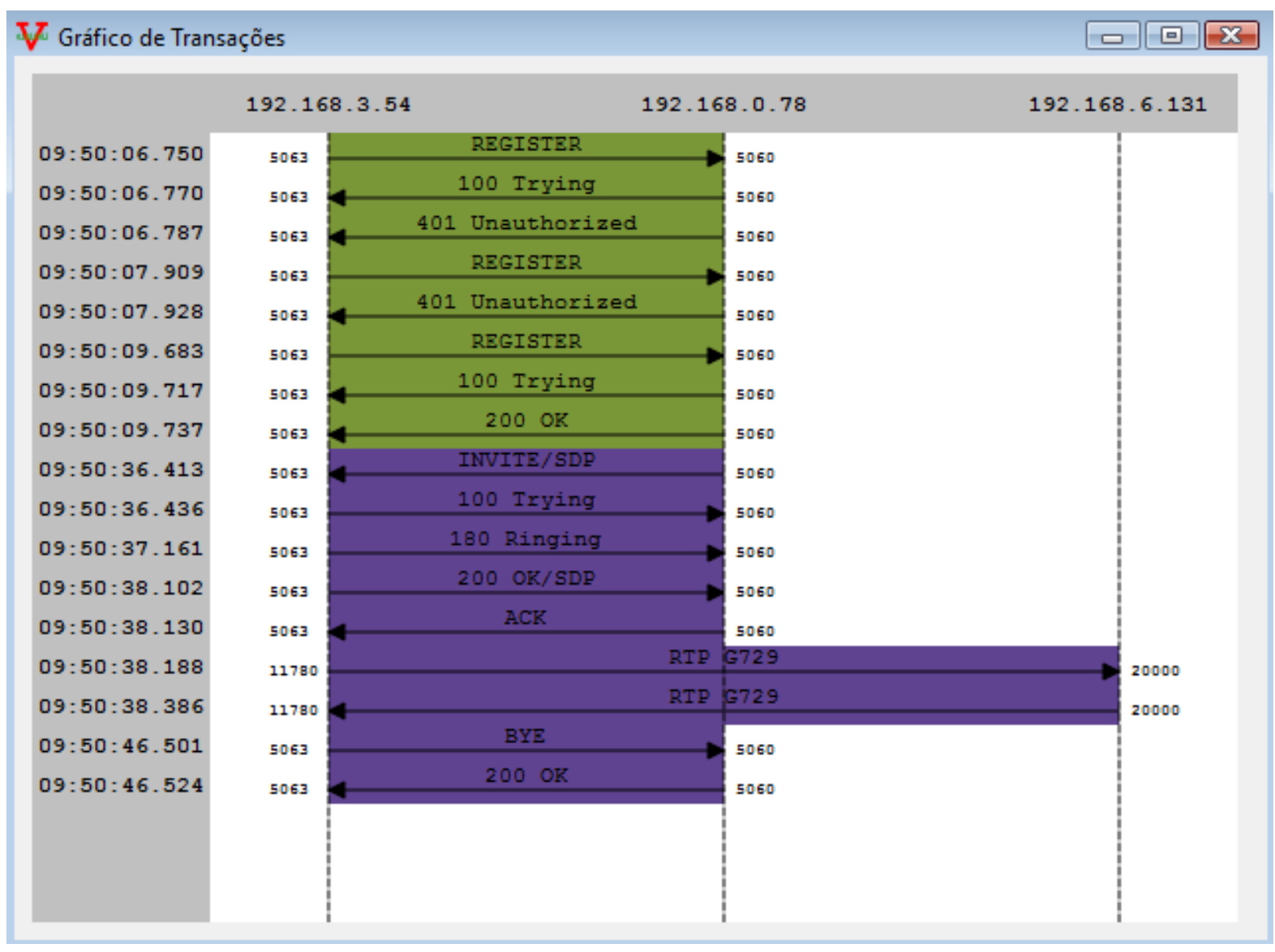

Figura 16 - Gráfico com transação de registro e chamada.

Quando duas transações são exibidas na tela, as mensagens de cada uma são apresentadas em cores diferentes, para que, assim, o usuário possa diferenciar pacotes de transações diferentes.

\subsubsection{Exibição de gráfico com número de transações}

a) Necessidade:

Em certos casos, é interessante observar a quantidade de um determinado tipo de transação em relação a outras, por exemplo, o número de requisições de registro em relação ao número de chamadas. Isso pode auxiliar o analista do sistema a detectar excessos de pedidos de registro ou outro tipo de requisição.

b) Funcionamento:

O VolPFix contabiliza o número de transações de INVITE, REGISTER, OPTIONS e NOTIFY, que são as mais comuns de acontecerem num sistema de telefonia IP, e exibe um gráfico como o da Figura 17. 
Tipos de Transações

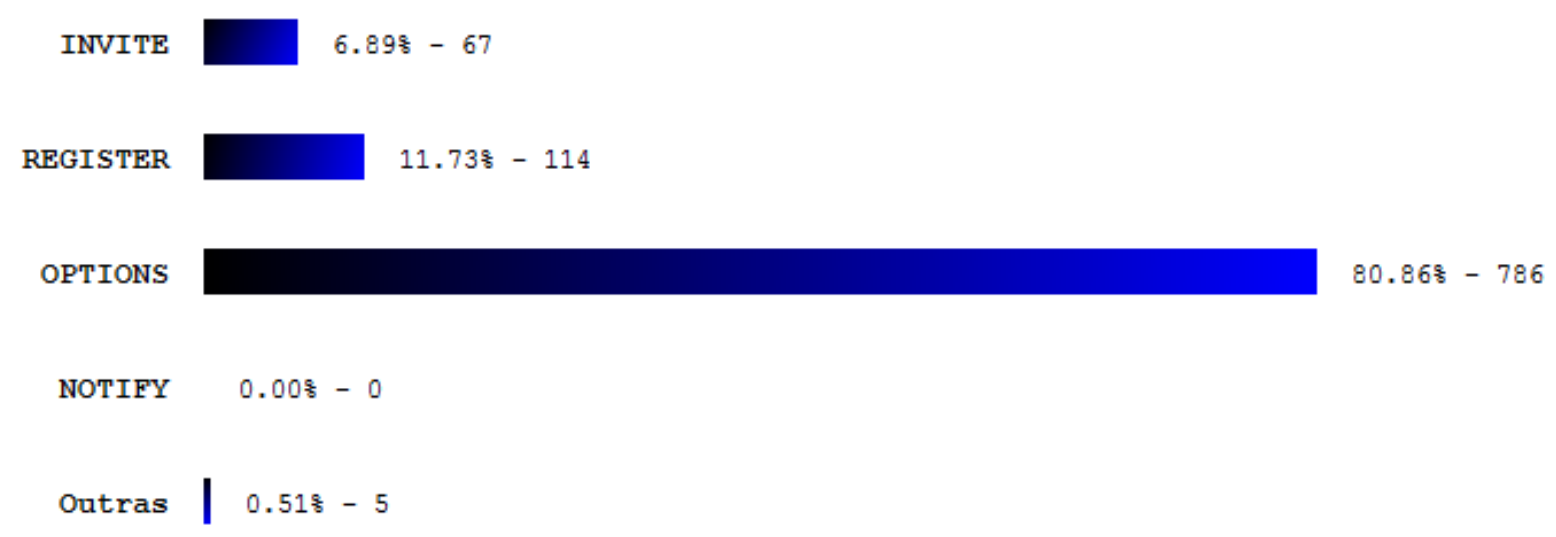

Figura 17 - Gráfico com número de transações.

O gráfico, em forma de barras horizontais, mostra a porcentagem em relação ao total e, também, a quantidade absoluta no contexto de análise.

No exemplo acima, pode-se observar uma grande quantidade de requisições OPTIONS em relação a outras requisições.

Para acessar todos os tipos de gráficos de estatísticas de requisições, o usuário deve acessar a opção "Estatísticas" no menu "Ferramentas".

\subsubsection{Exibição de gráfico com estatísticas de fechamento de chamadas}

a) Necessidade:

Um dos indicativos de que um sistema de telefonia está se comportando bem é a porcentagem de chamadas com sucesso em relação às não completadas corretamente. Essa informação deve ser exibida de forma clara e objetiva em um gráfico.

b) Funcionamento:

Essa funcionalidade é útil para exibir algumas estatísticas das causas de fechamento de chamadas, contabilizando, por exemplo, quantas chamadas foram completadas com sucesso, quantas foram canceladas, rejeitadas ou negadas.

A Figura 18 mostra um exemplo da funcionalidade: 
Estado de Chamadas

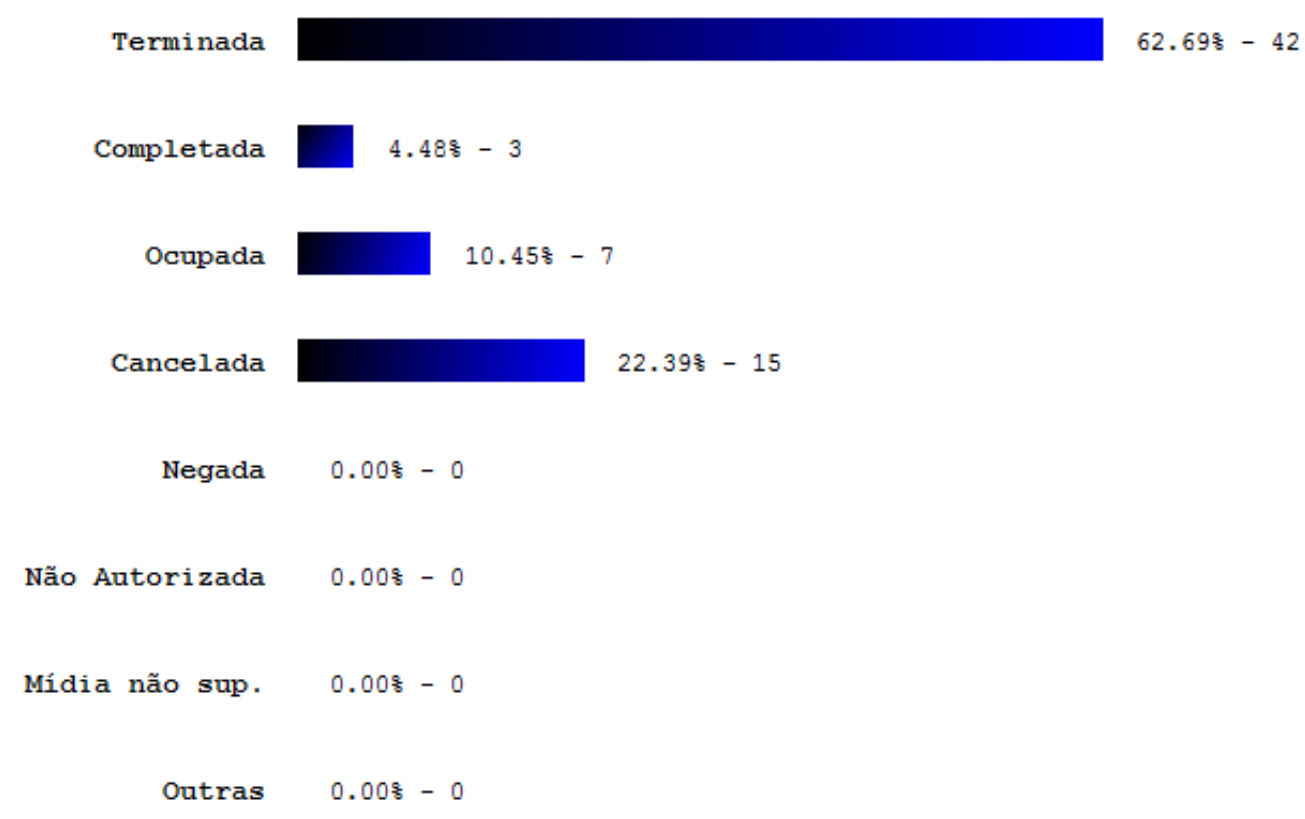

Figura 18 - Gráfico com estatísticas de fechamento de chamadas.

Com o gráfico acima, o usuário pode observar como está a eficiência de chamadas do sistema de telefonia IP e ainda ser alertado sobre um possível problema, caso o número de chamadas ocupadas ou negadas esteja alto.

Cada estado apresentado no gráfico de fechamento de chamadas tem o seguinte significado:

- Terminada: chamadas onde o desligamento aconteceu de forma correta, com o envio do BYE por uma das partes da transação;

- Completada: chamadas onde aconteceu somente o atendimento com a mensagem de resposta 200 oK. Provavelmente, o restante da transação não foi capturado até o momento da análise;

- Ocupada: chamada não completada, pois o usuário estava ocupado. Nessa situação, o UAS responde com a mensagem 486 Busy Here;

- Cancelada: requisições de chamadas canceladas com a mensagem CANCEL enviada por uma das partes, antes que acontecesse 0 atendimento pelo chamado;

- Negada: requisição que não chegou a ser completada, e que foi negada por algum motivo, por exemplo, usuário ausente ou não encontrado;

- Não Autorizada: o servidor solicitou autenticação para o requisitante da chamada, mas essa não foi autorizada. O UAS respondeu com a mensagem 401 Unauthorized ou 407 Proxy Authentication Required;

- Mídia não suportada: situação onde o UAC envia uma requisição de chamada com um codificador de voz ou vídeo não suportado pelo UAS e este envia a mensagem de resposta 415 Unsupported Media Type. Em alguns casos - UAS pode responder com essa mensagem quando não consegue entender o SDP da mensagem de requisição ou de atendimento da chamada; 
- Outras: qualquer outro estado da transação que não sejam nenhum dos descritos acima.

\subsubsection{Exibição de gráfico de número de chamadas por usuário ou máquina}

a) Necessidade:

Em certos casos é interessante contabilizar a utilização do sistema de telefonia IP, considerando o número de chamadas de um determinado usuário ou máquina na rede. Isso é importante também para descobrir usuários que estejam fazendo tentativas sucessivas de pedidos de chamadas e que não estão tendo sucesso. Esse fato pode ser prejudicial ao sistema de telefonia IP e deve ser cessado o quanto antes, para não congestionar os servidores.

b) Funcionamento:

O VolPFix exibe vários gráficos discriminando a quantidade de transações de chamada de cada usuário ou máquina do sistema de telefonia IP.

A Figura 19 mostra o gráfico de chamadas originadas pelos usuários, onde a informação da primeira coluna é o número do usuário, a segunda é a porcentagem de ligações realizadas em relação ao total e a terceira é o número absoluto de chamadas. 
Número de Chamadas do Usuário

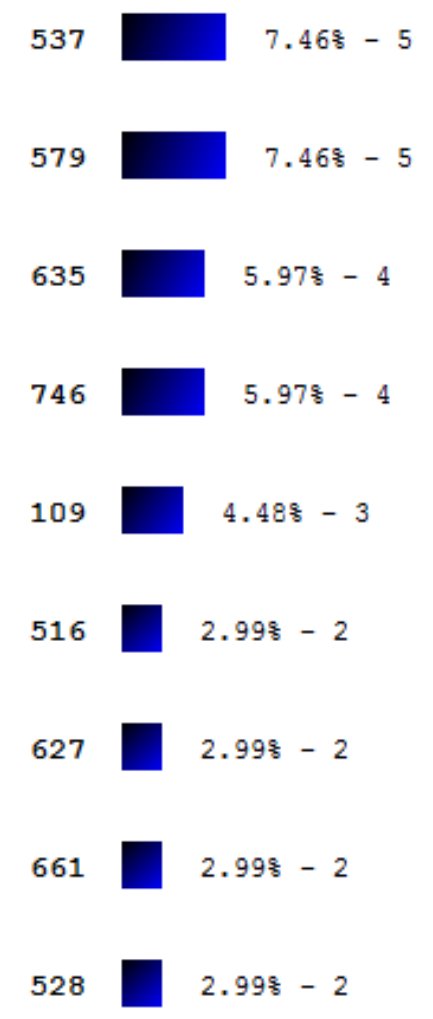

Figura 19 - Gráfico com o número de chamadas do usuário.

Com esse tipo de gráfico, o analista pode observar a utilização do sistema por usuário, identificando quantas ligações cada um deles originou no intervalo de tempo de análise.

A Figura 20 mostra o gráfico com as estatísticas de chamadas com destino aos usuários, onde a informação da primeira coluna é o número do usuário receptor, a segunda é a porcentagem de ligações recebidas em relação ao total e a terceira é o número absoluto de chamadas. 
Número de Chamadas para o Usuário

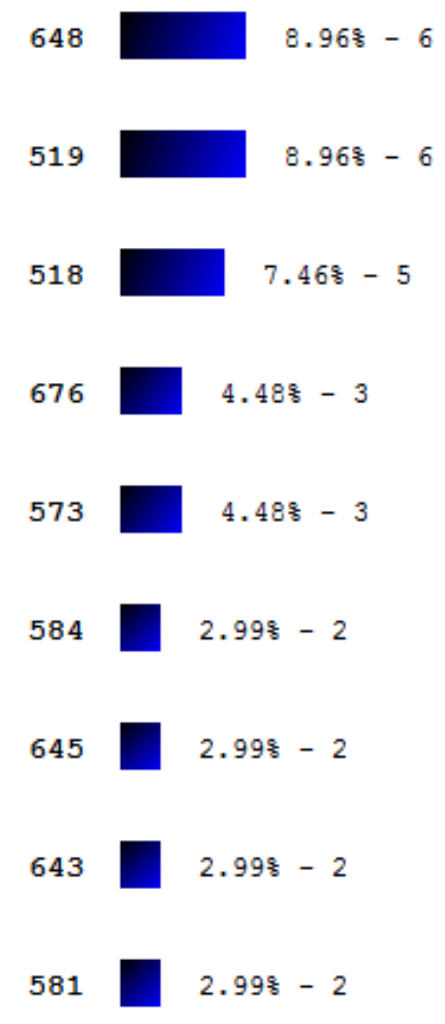

Figura 20 - Gráfico com número de chamadas para o usuário.

O VolPFix exibe, ainda, gráficos de chamadas relacionados às máquinas presentes no sistema de telefonia IP, o que poderá ser observado nos próximos gráficos.

A Figura 21 mostra o gráfico com o número de chamadas que partiram dos endereços IP das máquinas presentes no sistema: 
Número de Chamadas do Endereço

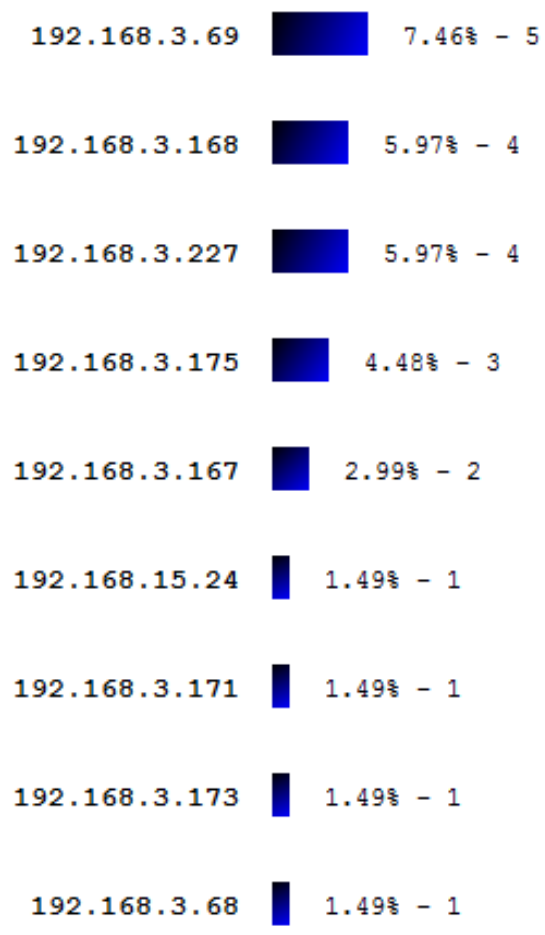

Figura 21 - Gráfico com número de chamadas do endereço.

Além de trazer informações sobre a utilização do sistema de telefonia, em termos de chamadas, o gráfico acima também pode alertar sobre possíveis ataques vindos de um endereço IP específico dentro ou fora da rede local dos equipamentos.

A Figura 22 mostra o gráfico com o número de chamadas para os endereços IP dos equipamentos no sistema: 
Número de Chamadas para ○ Endereço

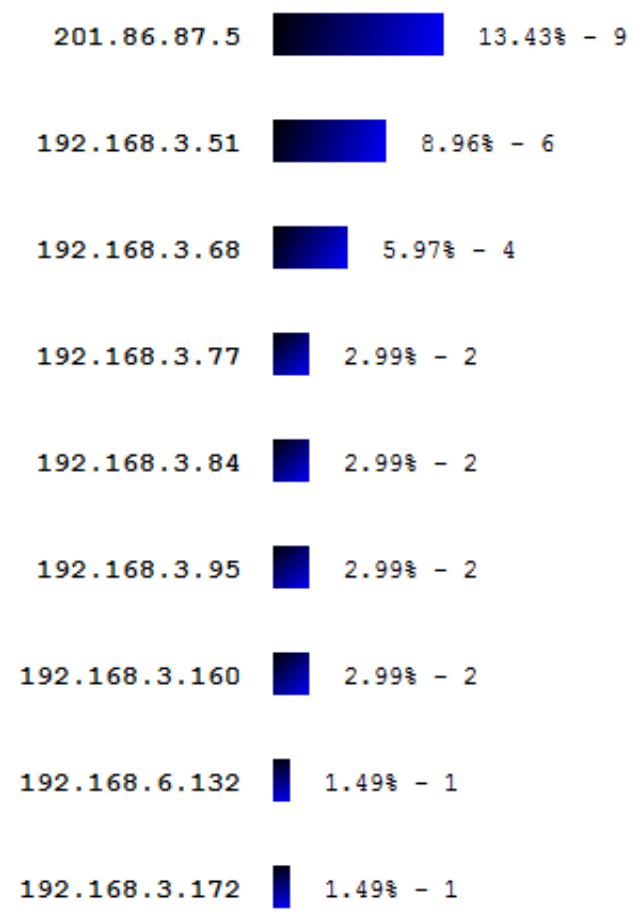

Figura 22 - Gráfico com número de chamadas para o endereço.

Da mesma forma, o analisador pode observar se um determinado equipamento está com excesso de serviço em relação ao número de chamadas que estão sendo direcionadas a ele.

\subsubsection{Exibição de gráfico com estatísticas de pedidos de registros}

a) Necessidade:

Avaliar somente as transações de chamada nem sempre é o suficiente para diagnosticar problemas em um sistema de telefonia IP. Em algumas situações, analisar o comportamento dessas transações é necessário para solucionar casos relacionados ao servidor de registro.

b) Funcionamento:

O VolPFix possui um gráfico com a estatística de pedidos de registro total do sistema, apresentando a contabilidade das requisições que tiveram sucesso e as que não foram completadas corretamente.

A Figura 23 mostra um exemplo da funcionalidade: 
Estado de Registros

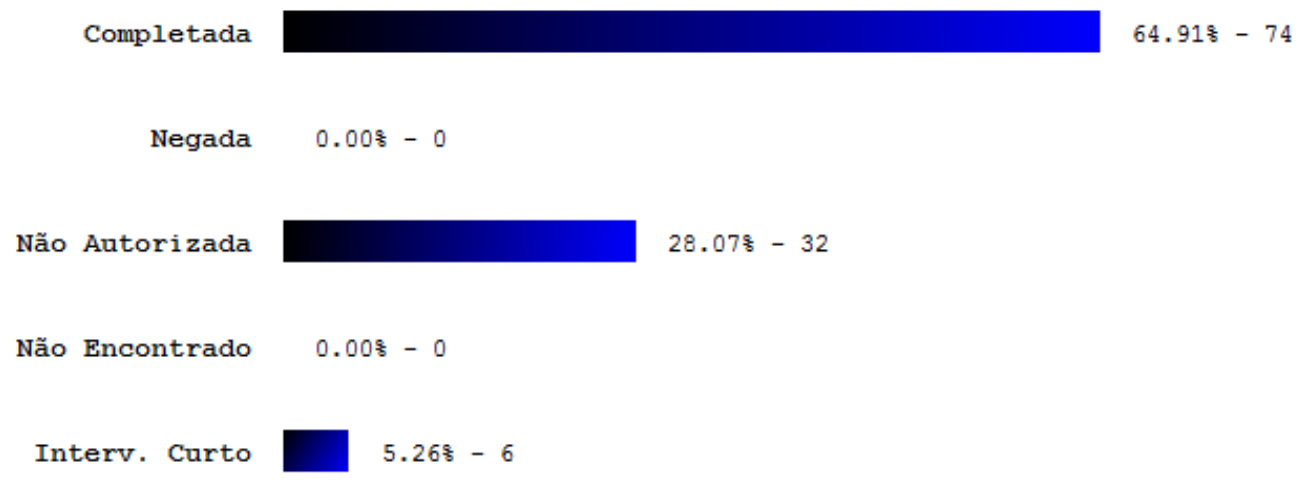

Figura 23 - Gráfico com estatísticas de pedidos de registro. significado:

- Completada: requisição de registro que foi bem-sucedida. Servidor de registro respondeu com a mensagem 200 OK;

- Negada: requisição que foi negada pelo servidor de registro, por exemplo, quando ele não está aceitando pedidos de registros;

- Não Autorizada: o servidor solicitou autenticação para o requisitante do registro, mas esse não foi autorizado. O UAS respondeu com a mensagem 401 Unauthorized;

- Não Encontrado: o servidor negou a requisição de registro com a mensagem 404 Not Found, indicando que o nome de usuário utilizado na requisição de registro não existe;

- Intervalo Muito Curto: o UAC fez uma requisição de registro ao UAS, com intervalo de tempo muito curto e recebeu a mensagem 423 Interval Too Brief como resposta, indicando que ele deve reformular um novo pedido com o tempo mínimo informado nessa mensagem.

\subsubsection{Exibição de gráfico de número de registros por usuário ou máquina}

a) Necessidade:

Avaliar a quantidade de pedidos de registro que um determinado usuário ou máquina está enviando é importante para verificar se não está havendo um número de mensagens muito grande durante um intervalo de tempo, já que isso nem sempre é necessário. Da mesma forma, é importante verificar se um servidor de registro está recebendo uma grande quantidade de requisições ou até mesmo um ataque de vindo de um endereço IP desconhecido. 
b) Funcionamento:

O VolPFix, na mesma janela de gráficos com estatísticas, exibe as seguintes informações relativas à requisições de registro:

- Número de registros do usuário;

- Número de registros do endereço IP;

- Número de registros para o endereço IP.

Não faz sentido existir um gráfico mostrando o número de pedidos de registro para um determinado usuário, como no gráfico de números de chamadas, pois não há essa situação nas requisições de registro.

A Figura 24 mostra um exemplo do número de registros dos usuários.

$$
\text { Número de Registros do Usuário }
$$

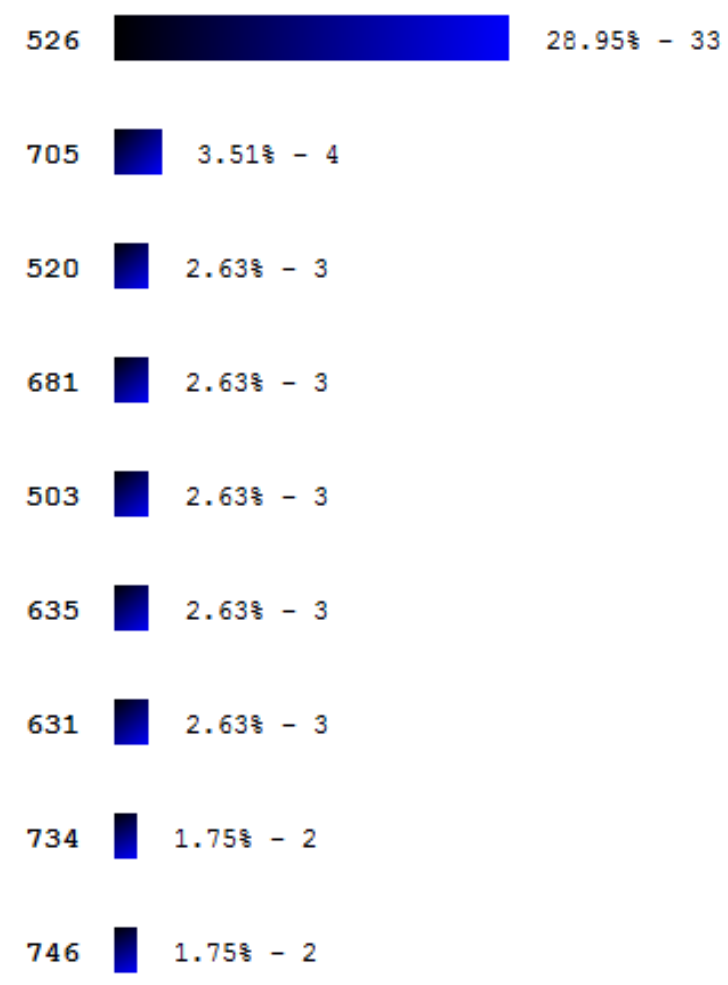

Figura 24 - Gráfico com número de registros do usuário.

Nesse exemplo, o analisador poderia tomar atitudes para verificar o motivo pelo qual o usuário de número 526 está realizando mais pedidos do que os demais. Provavelmente ele está configurado com intervalo de tempo menor que os demais. Se houvesse muitos desses casos em um sistema de telefonia IP, o servidor de registros poderia ficar sobrecarregado.

A Figura 25 mostra um exemplo de gráfico com o número de registros com destino aos endereços IP: 
Número de Registros do Endereço

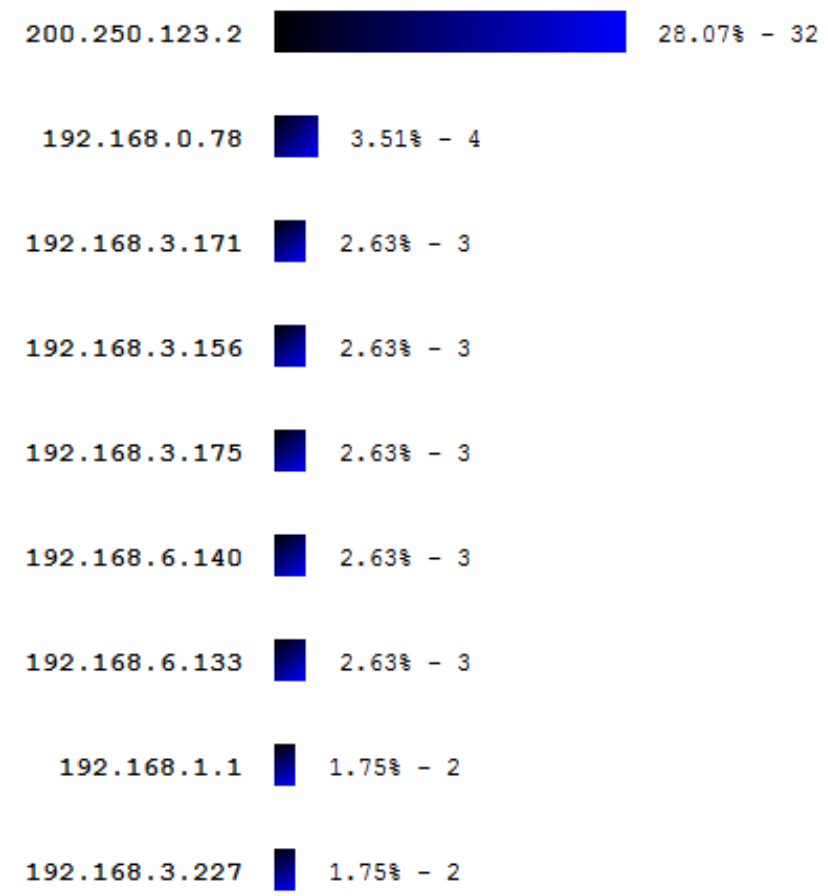

Figura 25 - Gráfico com número de registros do endereço.

Através do gráfico acima, o analisador pode verificar os endereços IP com maior número de pedidos de registro, podendo até indicar um ataque de requisições, caso o endereço IP em questão seja desconhecido. IP.

A Figura 26 mostra um exemplo do número de registros para os endereços

Número de Registros para Endereço

Figura 26 - Gráfico com número de registros para o endereço. 
No gráfico com o número de registros para os endereços IP, é possível observar se os servidores estão com uma carga excessiva de pedidos durante o intervalo de tempo de captura realizado.

Determinar a quantidade máxima de requisições suportada por um servidor de registro não é uma tarefa complexa, pois existem vários aplicativos gratuitos que realizam esse tipo de ensaio. Dependendo da estrutura de hardware e do software de um servidor, esse número pode chegar a centenas ou até milhares de requisições por segundo, mesmo em um equipamento de pequeno porte.

A preocupação com os gráficos listados nessa seção não se deve apenas aos servidores de registro, mas também ao consumo desnecessário de rede, pois não há necessidade de pedidos em curtos intervalos de tempo de um mesmo usuário, a não ser que ele esteja em um dispositivo móvel que troca de rede várias vezes num intervalo de tempo pequeno.

\subsubsection{Filtro de transações}

a) Necessidade:

Em muitos dos casos, quando se tem uma grande quantidade de transações e deseja-se analisar somente alguns tipos específicos ou aquelas com determinados usuários ou endereços, é conveniente fazer uma filtragem para tornar o processo de análise mais limpo e rápido.

b) Funcionamento:

Através da lista de transações, como descrito na Seção 4.2.6, essa ferramenta permite ao usuário filtrar as requisições com base nos seguintes parâmetros:

- Tipo de transação;

- horário de início;

- endereço IP de origem;

- endereço IP de destino;

- usuário de origem;

- usuário de destino;

- estado de finalização da transação.

A Figura 27 mostra a tela utilizada para configuração do filtro: 


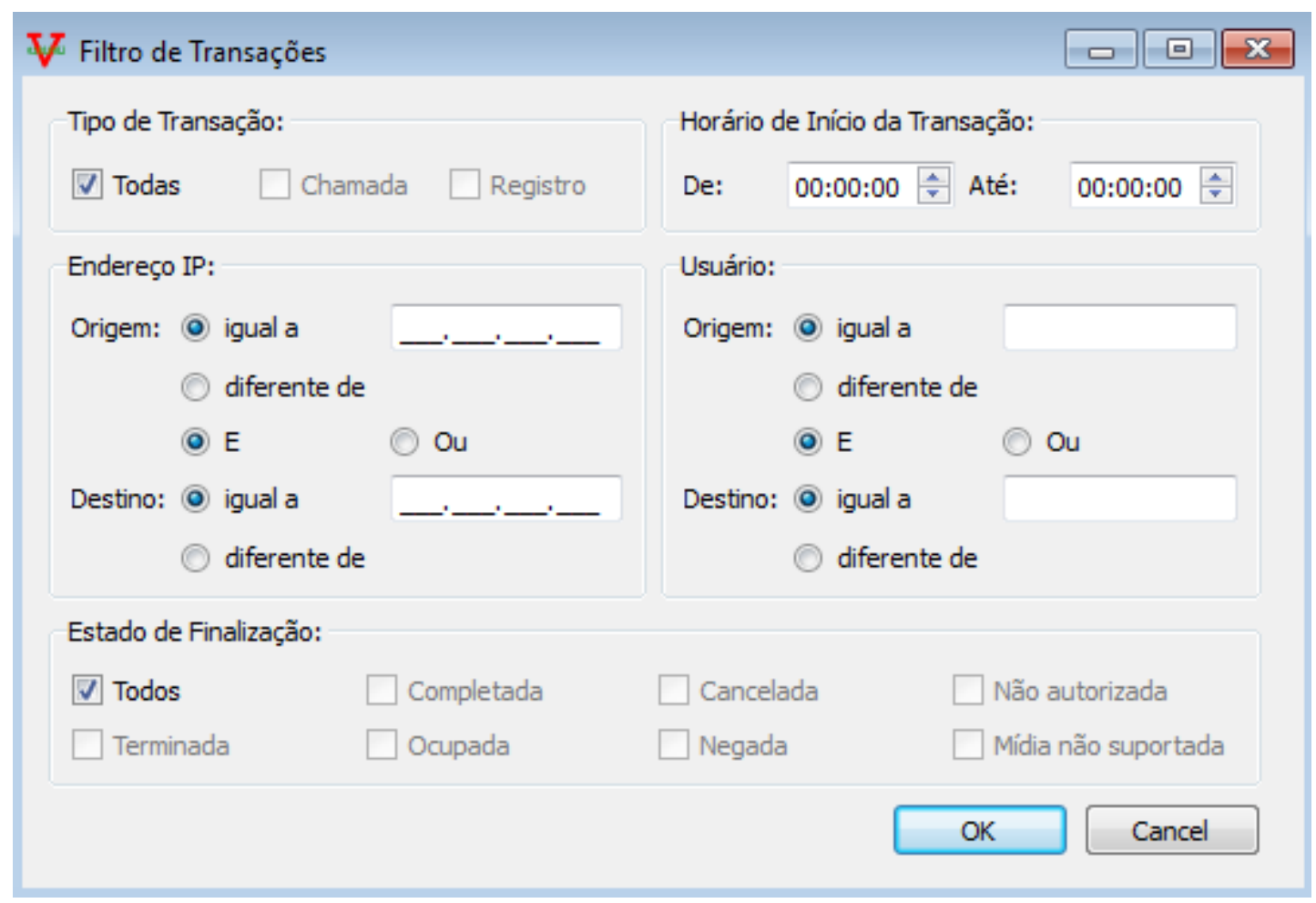

Figura 27 - Tela de filtro de transações.

As opções selecionadas pelo usuário nessa tela serão aplicadas à tela com a lista de transações, exibindo somente aquelas que corresponderem às opções selecionadas.

\subsubsection{Medição de jitter, perda de pacotes e erros de sequência}

a) Necessidade:

Uma das maiores preocupações dos administradores dos sistemas de telefonia IP é identificar os possíveis problemas causados por deficiências da infraestrutura de rede, como perda de pacotes e latência, fazendo um estudo dos impactos na qualidade das ligações de VolP.

b) Funcionamento:

O VolPFix traz informações de jitter, perda de pacotes e erros de sequência nos fluxos RTP das chamadas, assim como é feita em outras ferramentas do gênero.

A partir da lista de transações exibida no VolPFix, o usuário pode selecionar as transações de chamada que deseja analisar, clicar com o botão direito e selecionar a opção "Relatório", onde poderá verificar os parâmetros de jitter, perda de pacotes e erros de sequência das chamadas selecionadas. 
A Figura 28 mostra um trecho do relatório, onde é exibido o jitter, a perda de pacotes e os erros de sequência de três chamadas.

\begin{tabular}{cccc}
\hline Jitter Médio Org. [s] & Jitter Máx. Org. [s] & Perda Pacotes Org. [\$े] & Erro Sequência Org. \\
\hline 0.000033 & 0.000063 & 0.000000 & 0 \\
\hline 0.000064 & 0.000085 & 7.354555 & 1 \\
\hline 0.005929 & 0.767477 & 5.832212 & 2
\end{tabular}

Figura 28 - Relatório de jitter, perda de pacotes e erro de sequência.

$\mathrm{Na}$ tela de relatório são exibidas as seguintes informações sobre as transações selecionadas pelo usuário:

- Número da transação;

- horário de início;

- horário de finalização;

- tipo da transação;

- codificador de áudio, em transações de chamada;

- endereço IP de origem;

- usuário origem que solicitou a requisição;

- endereço IP de destino;

- usuário destino;

- estado de finalização da transação;

- duração em transações de chamada;

- jitter médio, em segundos, do fluxo de áudio do originador, em transações de chamada;

- jitter máximo, em segundos, do fluxo de áudio do originador, em transações de chamada;

- perda de pacotes do fluxo de áudio do originador, em transações de chamada;

- erros de sequência do fluxo de áudio do originador, em transações de chamada;

- jitter médio, em segundos, do fluxo de áudio do receptor, em transações de chamada;

- jitter máximo, em segundos, do fluxo de áudio do receptor, em transações de chamada;

- perda de pacotes do fluxo de áudio do receptor, em transações de chamada;

- erros de sequência do fluxo de áudio do receptor, em transações de chamada.

\subsubsection{Detecção de mudez total ou parcial em chamadas}

a) Necessidade:

Detectar se uma chamada ficou totalmente sem áudio ou teve períodos de mudez ao longo do tempo não é uma tarefa fácil de ser feita. Diferentemente da 
análise das mensagens de sinalização, que não passam de algumas unidades, a quantidade dos pacotes de voz é muito grande, o que dificulta uma análise criteriosa para descobrir pontos de picotes ou ausência significativa de áudio.

b) Funcionamento:

O VolPFix é capaz de identificar a mudez total ou parcial através da detecção da ausência de pacotes RTP em um ou em ambos os sentidos. Os motivos que levam a esse acontecimento podem ser vários, mas qualquer um deles pode ser detectado, uma vez que a interrupção do fluxo de pacotes, quando acontece de forma intencional, é sinalizada através de um bit dentro do cabeçalho RTP. Um dos motivos para o acontecimento desse fato é quando um dos sistemas possui mecanismos de detecção automática de voz para interrupção do fluxo em momentos de silêncio.

A detecção de falta de áudio por ausência de pacotes RTP só poderá ser considerada válida se alguns dos pacotes do fluxo, em pelo menos um sentido, puderem ser capturados no início da chamada. Nos casos onde houve somente a captura dos pacotes de sinalização, sem nenhum pacote do fluxo RTP dessa transação, não será possível diagnosticar problemas como esse.

Na mesma tela que exibe o relatório com informações de jitter, o usuário pode ter um diagnóstico do fluxo de áudio da chamada.

O VolPFix sinaliza na coluna "Codificador", colorindo o campo da transação para problemas de fluxo RTP, da seguinte forma:

- Com a cor vermelha, para problemas de alta gravidade;

- com a cor amarela, para problemas de média gravidade;

- com a cor azul, para situações simplesmente informativas, não necessariamente um problema.

Quando o usuário posiciona o cursor em cima desse campo, o VolPFix mostra uma mensagem dizendo o tipo e a gravidade do problema, e, ao clicá-lo, um relatório mais detalhado é exibido na parte inferior da tela de relatório.

A Figura 29 mostra um exemplo onde houve momentos de ausência do fluxo de áudio do receptor da chamada. 


\begin{tabular}{|l|c|cccc|}
\hline Número & Início & Fim & Tipo & Codificador & IP Origem \\
\hline 1 & $10: 08: 27.958501$ & $10: 09: 13.385095$ & INVITE & g711u & 192.168 .6 .131 \\
\hline
\end{tabular}

Figura 29 - Detecção de momentos de ausência de fluxo de áudio.

Na Figura 30 é exibido um exemplo mostrando um problema mais grave em relação ao fluxo RTP, onde não foi detectado o fluxo RTP do receptor da chamada. Problemas assim podem acontecer quando um dos elementos está atrás de um NAT [EGE94] e não conseguiu abrir o fluxo de áudio para o IP correto do destinatário, ou ainda quando aconteceu algum problema na máquina de geração dos pacotes RTP.

O VolPFix detecta situações desse tipo, mas não esclarece a causa do problema, uma vez que não há evidências concretas na captura que possibilitem uma análise conclusiva de forma automática. Fica a cargo do usuário analisador mais experiente investigar as possíveis causas.

\begin{tabular}{|c|c|c|c|c|c|}
\hline Número & Início & Fim & Tipo & Codificador & IP Origem \\
\hline \multirow[t]{2}{*}{5} & $11: 04: 34.398935$ & $11: 04: 47.253670$ & INVITE & G729 & 192.168 .6 .131 \\
\hline & & & & \multicolumn{2}{|c|}{ Erro de fluxo RTP de alta gravidade } \\
\hline 1 & & III & $\square$ & & \\
\hline
\end{tabular}

- Não foi detectado fluxo RTP do receptor da chamada.

Figura 30 - Detecção de ausência de fluxo RTP num sentido.

$\mathrm{Na}$ Seção 4.4.13, que trata sobre os detalhes de implementação da funcionalidade, será descrito, a partir de gráficos, como o VolPFix conseguiu detectar o problema acima. 


\subsubsection{Detecção de transações com erros de sinalização}

a) Necessidade:

Erros de sinalização são os casos mais difíceis de serem detectados por uma ferramenta puramente de análise de pacotes, pois o protocolo SIP é complexo e extenso.

b) Funcionamento:

A proposta do trabalho foi fazer com que sejam cobertos alguns casos mais comuns, mas que exijam um conhecimento mínimo de SIP pelo usuário operador do VolPFix.

Como dito anteriormente, embora os equipamentos de telefonia IP sigam os padrões propostos pelas recomendações padronizadas, ainda há margem para interpretações diferentes, o que causa incompatibilidade entre equipamentos de fabricantes diferentes. Ainda, nem todos os casos e estados são testados de forma exaustiva, a ponto de cobrir qualquer tipo de situação do protocolo de sinalização.

Os casos que foram cobertos pelo VolPFix são fundamentados na especificação da ETSI [MTS07], criada para testes de conformidade do comportamento de equipamentos de telefonia IP baseados em SIP.

O VolPFix alerta o usuário analisador sobre a detecção de problemas ou erros de sinalização, colorindo o campo "Tipo" da transação da seguinte forma:

- Com a cor vermelha, para problemas de alta gravidade;

- com a cor amarela, para problemas de média gravidade;

- com a cor azul, para situações apenas informativas, não necessariamente um problema.

Ainda, quando o usuário clica sobre a transação destacada, um relatório mais detalhado aparece na parte inferior da tela. 


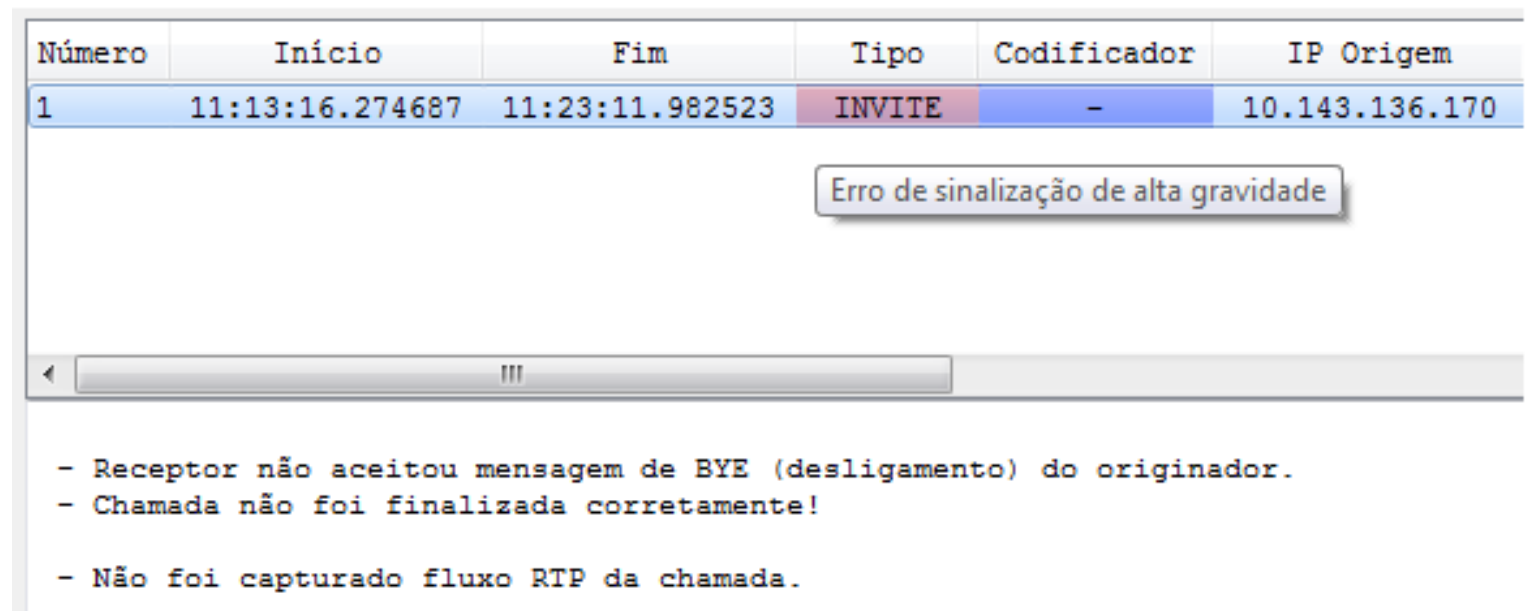

Figura 31 - Relatório com problema de sinalização.

A Figura 31 mostra um exemplo da utilização da ferramenta de relatório, mostrando um problema em que o receptor não aceitou a mensagem BYE de desligamento enviada pelo originador. Esse tipo de ocorrência faz que o receptor mantenha o fluxo RTP ainda ativo com o originador e o sistema de bilhetagem continue contabilizando o tempo da ligação, até que o usuário que esteja operando o terminal desligue efetivamente a chamada.

Ainda no exemplo acima, o VolPFix detectou a ausência do fluxo RTP da chamada, mesmo ela tendo sido estabelecida normalmente. Nesse caso, pode ter ocorrido negociação do fluxo RTP através de outros endereços IP que não foram capturados, não acontecendo um problema realmente. Porém, o usuário é informado sobre a ocorrência.

A Figura 32 mostra outro exemplo de detecção de problema de sinalização realizado automaticamente pelo VolPFix, porém com mais detalhes sobre o que realmente aconteceu de errado na mensagem de BYE enviada pelo originador.

No caso da Figura 32, o originador enviou a mensagem de desligamento da chamada com o campo CSeq com valor inferior ao da requisição inicial, por isso o VolPFix acusou o fato e informou os valores do campo em cada mensagem.

Com funcionalidades como essa, o VolPFix traz grandes vantagens em relação a outras ferramentas de VolP, pois não é necessário que um usuário analisador com experiência em SIP, tenha de verificar mensagem por mensagem, campo por campo, a fim de descobrir um problema específico. Da mesma forma, um usuário com pouco conhecimento pode ter respostas mais claras sobre problemas de sinalização. 


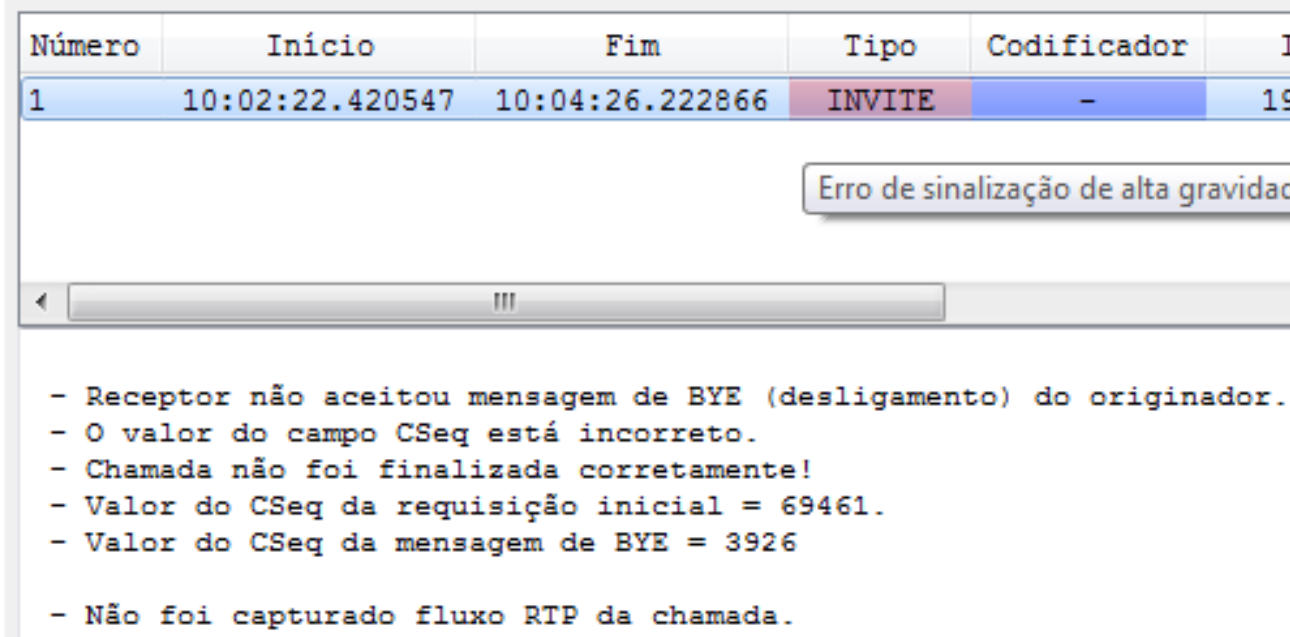

Figura 32 - Detecção de problema de fechamento de chamada.

$\mathrm{Na}$ Seção 4.4.13, que trata sobre os detalhes de implementação da funcionalidade, será descrito, através de mais gráficos, como o VolPFix conseguiu detectar o problema acima.

\subsubsection{Informativo com causas de problemas com transações}

a) Necessidade:

Além dos problemas de sinalização, provocados por erros nos equipamentos, ainda podem acontecer casos onde toda a sinalização está correta, porém a requisição não pode ser aceita ou não consegue ser completada. Nesses casos, os equipamentos de telefonia IP costumam sinalizar para o usuário a ocorrência, porém nem sempre de forma clara e precisa.

b) Funcionamento:

O VolPFix trata de casos, evidenciando as transações que não puderam ser completadas, por situações como:

- Senha de autenticação incorreta;

- usuário de origem ou destino inexistente;

- usuário de destino ocupado ou temporariamente indisponível;

- configuração de codificadores de voz incorreta;

- erros no agente que recebe a requisição;

- indisponibilidade do agente destino;

- chamada cancelada.

As informações com as causas de problemas com as transações são exibidas na tela com a lista de transações, como mostra a Figura 33. 


\begin{tabular}{|c|c|c|c|c|c|c|c|}
\hline Número & Início & Tipo & IP Origem & Usuário Origem & IP Destino & Usuário Destino & Estado \\
\hline 28 & $09: 30: 01.929861$ & INVITE & 192.168 .3 .69 & 537 & 192.168 .1 .1 & 676 & Ocupada \\
\hline 44 & $09: 30: 21.040932$ & INVITE & 192.168 .3 .69 & 537 & 192.168 .1 .1 & 676 & Ocupada \\
\hline 63 & $09: 31: 02.553389$ & INVITE & 192.168 .3 .168 & 579 & 192.168 .1 .1 & 518 & Cancelada \\
\hline 92 & $09: 31: 50.715982$ & INVITE & 192.168 .1 .1 & 109 & 192.168 .6 .132 & 682 & Cancelada \\
\hline 119 & $09: 32: 42.226234$ & INVITE & 192.168 .1 .1 & 109 & 192.168 .3 .152 & 686 & Cancelada \\
\hline 195 & $09: 35: 26.386294$ & INVITE & 192.168 .1 .1 & 109 & 192.168 .3 .95 & 643 & Cancelada \\
\hline 213 & $09: 36: 07.808512$ & INVITE & 192.168 .3 .168 & 579 & 192.168 .1 .1 & 518 & Cancelada \\
\hline 255 & $09: 38: 06.884447$ & INVITE & 192.168 .1 .1 & 646 & 192.168 .3 .51 & 648 & Cancelada \\
\hline 283 & $09: 39: 29.812879$ & INVITE & 192.168 .3 .227 & 746 & 192.168 .1 .1 & 573 & Ocupada \\
\hline 294 & $09: 39: 55.670407$ & INVITE & 192.168 .3 .227 & 746 & 192.168 .1 .1 & 634 & Ocupada \\
\hline 295 & $09: 39: 46.779484$ & INVITE & 192.168 .3 .227 & 746 & 192.168 .1 .1 & 573 & Ocupada \\
\hline 374 & $09: 43: 45.580461$ & INVITE & 192.168 .3 .168 & 579 & 192.168 .1 .1 & 518 & Cancelada \\
\hline 397 & $09: 44: 43.612067$ & INVITE & 192.168 .3 .175 & 635 & 192.168 .1 .1 & 518 & Cancelada \\
\hline 427 & $09: 46: 23.246053$ & INVITE & 192.168 .3 .175 & 635 & 192.168 .1 .1 & 518 & Cancelada \\
\hline 432 & $09: 46: 41.253259$ & INVITE & 192.168 .3 .175 & 635 & 192.168 .1 .1 & 519 & Cancelada \\
\hline 441 & $09: 46: 41.574630$ & INVITE & 192.168 .1 .1 & 635 & 192.168 .3 .68 & 519 & Cancelada \\
\hline 461 & $09: 47: 45.359432$ & INVITE & 192.168 .1 .1 & 576 & 192.168 .3 .63 & 516 & Cancelada \\
\hline 548 & $09: 51: 54.983185$ & INVITE & 192.168 .1 .1 & 680 & 192.168 .3 .68 & 519 & Cancelada \\
\hline 713 & $10: 00: 45 \cdot 745474$ & INVITE & 192.168 .1 .1 & 546 & 192.168 .3 .160 & 534 & Cancelada \\
\hline
\end{tabular}

Figura 33 - Informativo com problemas de transações.

\subsubsection{Reprodução do áudio das chamadas com codificador G.711}

a) Necessidade:

Em algumas situações, quando nenhum erro aparente é evidenciado pela ferramenta no que diz respeito à qualidade de voz, ausência de áudio, atrasos ou picotes, é necessário ouvir o áudio da ligação para inferir o problema.

b) Funcionamento:

O VolPFix permite que o usuário possa ouvir o áudio das chamadas que forem completadas utilizando o codificador de voz G.711 [ITU72], considerando que os pacotes do fluxo de voz foram capturados corretamente e estão presentes no arquivo de captura.

A maior parte dos codificadores de voz não são gratuitos e necessitam de licença para serem utilizados. Por esse motivo, somente as chamadas com o G.711 têm a possibilidade de reprodução do seu áudio. Outros codificadores, como o G.729 [ITU07] e iLBC [AND04], que são os mais utilizados, não serão incorporados nessa funcionalidade para reprodução do áudio da chamada. Isso não significa que as demais funções do VolPFix não poderão funcionar caso a chamada utilize um desses codificadores. Serão propostas para trabalhos futuros, implementações para suportar os codificadores que são de código fonte aberto.

A Figura 34 mostra a tela utilizada para reprodução do áudio de chamadas que utilizaram o codificador G.711. 


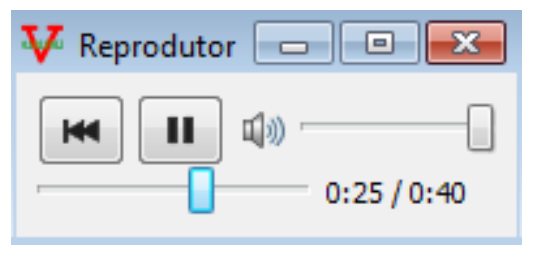

Figura 34 - Reprodutor de áudio de chamadas.

Para acessar a tela acima, o usuário deve clicar com o botão direito sobre uma chamada, na tela com a lista de transações, e escolher a opção "Reproduzir Áudio".

\subsection{Tecnologias e ferramentas utilizadas}

Nesta seção são apresentadas as tecnologias utilizadas para a construção do VolPFix, bem como outras ferramentas de apoio e testes.

\subsubsection{Linguagem de programação}

A linguagem utilizada no desenvolvimento é o $\mathrm{C}_{++}$, com auxílio do Qt, desenvolvido pela empresa Nokia [QT]. Qt é um arcabouço para desenvolvimento de aplicativos com interface gráfica de usuário em $\mathrm{C}_{++}$, que pode ser compilado para vários sistemas operacionais, como Windows, GNU/Linux, Mac OS X e outros [BLA08]. A licença utilizada é a LGPL.

Como ambiente integrado de desenvolvimento, foi utilizada a ferramenta Qt Creator, da própria Nokia, disponível gratuitamente no site do Qt. Com essa ferramenta foi possível editar, compilar e executar os programas criados em Qt, além de criar interfaces gráficas de usuário. O Qt Creator está disponível para Windows, GNU/Linux e Mac OS X.

\subsubsection{Capturador de pacotes de rede}

Muitas ferramentas de captura e análise de pacotes de rede trabalham com arquivos no formato pcap [PCAP], que armazena todas as informações dos pacotes capturados em um arquivo único.

O VolPFix utilizou como padrão esse formato de arquivo, para salvar os pacotes e também abrir arquivos previamente capturados por outras ferramentas. Para isso, utilizou a biblioteca WinpCap [WINP], na versão para Windows. Para a versão GNU/Linux, a biblioteca utilizada foi a libpcap [TCPD], muito semelhante ao WinpCap, mas específica para rodar nesse sistema operacional. 


\subsubsection{Interpretador de mensagens SIP}

Para cumprir os objetivos propostos, o VolPFix teve de ser capaz de interpretar todas as mensagens SIP que estavam nos pacotes de rede capturados. Para isso foi utilizado um interpretador que recebe o texto de uma mensagem, faz a análise e identifica todos os campos e valores do cabeçalho e corpo de uma mensagem SIP.

A biblioteca utilizada para servir de interpretador é a oSIP [OSIP], que é compatível com o padrão proposto pela RFC3261.

Com a oSIP, foi possível transformar as mensagens SIP em estruturas que traduzem cada campo e seus valores. Sendo assim, depois de ter sido interpretada, é possível identificar os métodos de cada uma, as mensagens de cada transação, os parâmetros de negociação de sessão e todos os outros parâmetros que podem aparecer no SIP.

\subsubsection{Ferramentas e equipamentos de testes}

Durante a etapa de desenvolvimento e testes, foram utilizados algumas ferramentas e equipamentos que auxiliaram na geração de mensagens e fluxo de voz, captura de pacotes e interconexão de elementos SIP. A seguir uma breve descrição dessas ferramentas:

\section{a) $\underline{\text { X-Lite: }}$}

O X-Lite $[X L T]$ é um aplicativo para Windows e GNU/Linux, disponível gratuitamente, que faz a função de um telefone SIP em um PC. Com esse aplicativo é possível se registrar em um servidor, gerar e receber chamadas utilizando os mecanismos de multimídia do PC, através de alguns codificadores de voz de padrão aberto. $O$ aplicativo foi escolhido para ser um gerador de requisições e chamadas.

A Figura 35 mostra a tela inicial do aplicativo X-Lite. 


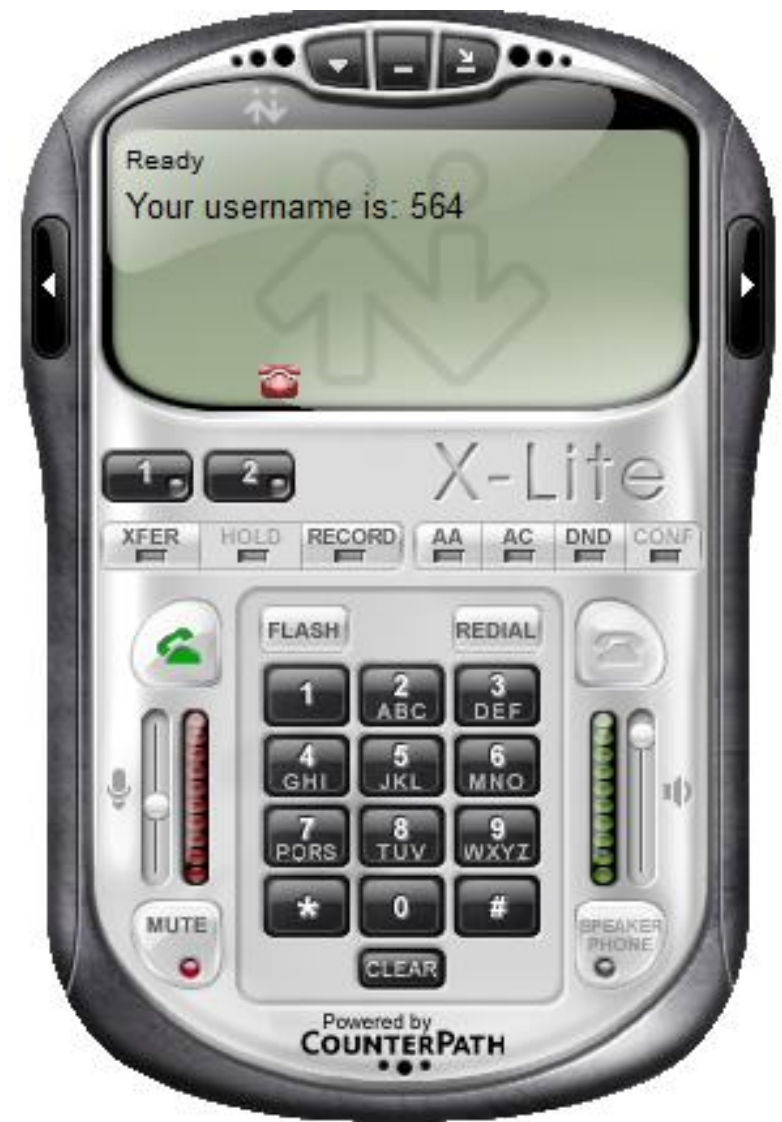

Figura 35 - Tela do aplicativo X-Lite.

b) Telefone IP Chatty:

O Chatty [CHAT] é um telefone IP que faz a mesma função que o X-Lite, porém não necessita de um computador para realizar seu trabalho. Ele pode ser conectado diretamente à rede de computadores através de sua interface Ethernet. Possui um teclado numérico e um visor de cristal líquido para exibir informações ao usuário das chamadas de VolP e permitir configurações básicas.

Esse aparelho telefônico VolP foi escolhido também para servir de gerador de requisições e chamadas VolP, pois ele é homologado pela Anatel (Agência Nacional de Telecomunicações) segundo o documento de requisitos técnicos [ANA10] aplicáveis para ensaios desse tipo de aparelho. Esse documento, em relação aos testes da máquina SIP dos aparelhos IP, baseia-se numa especificação [MTS07] desenvolvida pelo órgão ETSI (European Telecommunications Standards Institute), que reúne e especifica todos os comportamentos esperados de um equipamento VolP que trabalha com o protocolo SIP. A ETSI se baseou na RFC3261 para elaborar todos esses testes. A Anatel não especifica todos os testes recomendados pela ETSI, mas apenas alguns aplicáveis a adaptadores para telefônicos analógicos e telefones IP, como o Chatty. 
c) Trixbox:

O Trixbox [TRIX] é um PBX IP baseado no famoso Asterisk [AST], que é um software livre que transforma um PC numa plataforma de comunicação multimídia. Ambos são projetos com código fonte aberto.

Essa plataforma é um excelente PBX IP, com vários recursos adicionais, como correio de voz, unidade de resposta audível e outros. Porém, até o momento da escrita desta dissertação, ele não está totalmente aderente às normas da ETSI no que diz respeito ao comportamento de um equipamento VoIP baseado em SIP. Há trabalhos paralelos que estão empenhados em fazer com que o Asterisk se torne um equipamento que segue todas as normas para telefonia IP baseada em SIP.

Como ele ainda não é totalmente aderente às normas da ETSI, ele foi utilizado em testes onde o VolPFix pode detectar falhas na sinalização.

d) Ision IP:

O Ision [ISI] é um PBX híbrido (possui elementos IP, analógicos e digitais) de grande porte fabricado pela Leucotron Telecom. O equipamento está homologado pela Anatel, inclusive no que diz respeito às normas de testes de SIP.

\subsection{Detalhes de implementação}

A seguir, são apresentados o detalhamento sobre a implementação de cada função do VolPFix e como cada módulo foi construído para alcançar os objetivos propostos para o trabalho.

\subsubsection{Captura de pacotes}

Utilizando a biblioteca WinpCap [WINP] no Windows e libpcap [TCPD] no GNU/Linux, o VolPFix realiza a captura dos pacotes de rede em modo promíscuo a partir de uma interface de rede escolhida pelo usuário.

As duas bibliotecas, tanto para Windows quanto para GNU/Linux, são muito parecidas em se tratando de princípio de funcionamento, tendo apenas algumas variações nos nomes das funções e em seus parâmetros.

O processo utilizado pelo VolPFix para iniciar uma captura, realizado dentro do módulo "Capturador", é o seguinte:

- O VolPFix lista as interfaces de rede disponíveis na plataforma, como mostrado na Figura 10;

- o usuário escolhe a interface de rede para realização da captura de pacotes; 
- o usuário escolhe filtros de captura, por exemplo, somente pacotes UDP ou de uma determinada máquina;

- o processo de captura é iniciado pelo usuário;

- o VolPFix compila e aplica o filtro escolhido pelo usuário durante a captura na interface de rede selecionada;

- cada pacote que chega é adicionado em uma lista pela biblioteca, e é tratado dentro de uma thread da aplicação;

- eventualmente, cada pacote poderá ser salvo em um arquivo temporário ou escolhido pelo usuário.

O WinpCap e a libpcap possuem duas formas de entregar os pacotes recebidos através de uma interface de rede à aplicação que o utiliza:

- Receber o ponteiro de uma função para que seja chamada cada vez que um pacote é recebido ou;

- armazenar os pacotes em uma lista temporária e deixar a cargo da aplicação coletar os pacotes na medida do possível, até que a lista fique vazia e seja preenchida novamente com a chegada de novos pacotes.

Por questões de facilidade de implementação, o módulo "Capturador" implementa a segunda forma descrita acima, abrindo o dispositivo de rede para a captura e iniciando uma thread com alta prioridade para coletar os pacotes, para que possam ser enviados às camadas superiores da aplicação.

O mesmo processo é utilizado para abertura de arquivos em disco, para tornar as camadas superiores da aplicação independentes do modo de coleta de pacotes. A única diferença é que o módulo "Capturador" avisa a camada superior quando o final do arquivo é atingido.

\subsubsection{Análise de múltiplos arquivos gravados sequencialmente}

A funcionalidade descrita na Seção 4.2.4 é implementada inteiramente no módulo "Capturador" da aplicação, que realiza os seguintes passos:

- Recebe uma lista de arquivos, escolhidos pelo usuário, a serem abertos;

- realiza a abertura de um arquivo por vez, passando para o próximo quando encontra o fim de cada um;

- a cada pacote encontrado no arquivo, avisa a camada superior sobre o mesmo;

- quando encontra o fim do último arquivo, avisa a camada superior sobre o fato.

O procedimento descrito acima garante que todos os demais módulos do VolPFix trabalhem como se estivesse abrindo um único arquivo do disco. Porém, o usuário tem uma grande vantagem de abrir mão de procedimentos de mescla de arquivos, ou ainda, ter de analisar transações com mensagens dispersas em mais de um arquivo capturado. 
Obviamente, o processo consome recursos da máquina que realiza 0 trabalho, na proporção do tamanho de cada arquivo, uma vez que todos os arquivos selecionados pelo usuário são abertos e carregados para a memória.

\subsubsection{Identificação de pacotes de interesse}

Os pacotes de interesse para o VolPFix são, essencialmente, aqueles que trafegam e que utilizam o protocolo de transporte UDP. Porém, a análise não se restringe somente ao tipo do protocolo, uma vez que muitas outras aplicações utilizam o UDP para troca de mensagens, como, por exemplo, o serviço de DNS. Sendo assim, outros critérios são utilizados para a detecção dos pacotes relevantes de uma aplicação VoIP. Os critérios adotados são descritos abaixo.

a) SIP:

A técnica adotada para a caracterização de um pacote SIP consiste na identificação do nome do protocolo e de sua versão, presentes na primeira linha do payload UDP. O VolPFix analisa somente pacotes da versão 2.0, que é a atualmente utilizada.

Para mensagens de resposta, a primeira linha, chamada de linha de status, tem o seguinte formato:

SIP-Version SP Status-Code SP Reason-Phrase CRLF

Sendo assim, basta identificar que o primeiro campo dessa linha seja "SIP/2.0", para caracterizar que é uma mensagem SIP de resposta.

Para as mensagens de requisição, a primeira linha, chamada de linha de requisição, possui o seguinte formato:

Method SP Request-URI SP SIP-Version CRLF

Dessa forma, a identificação é ligeiramente mais trabalhosa, consistindo no mesmo princípio de procurar pelo nome e versão do protocolo somente na primeira linha para caracterizar como uma mensagem SIP de requisição.

Tendo o pacote sido marcado como do protocolo SIP, ele é encaminhado para a parte que realiza a interpretação completa do pacote. Essa técnica garante uma agilidade na identificação e interpretação dos pacotes de uma rede, não passando toda e qualquer mensagem UDP pelo interpretador.

b) $\underline{\text { RTP: }}$

O mecanismo utilizado para identificação de pacotes RTP [AGR08], baseia-se na prévia detecção das sessões através das mensagens de sinalização utilizadas para negociação e estabelecimento. Após a identificação dessas sessões, o VolPFix 
passa a identificar os pacotes UDP que se encaixem em pelo menos uma das condições de endereço IP ou porta de origem ou destino.

O VolPFix vai além e considera outros fatores que tornam a identificação dos pacotes RTP mais segura. Tais fatores são analisados em conjunto com o endereço IP e porta de destino e origem, mas só são considerados após algumas unidades de pacotes terem aparecido no início do fluxo. Isso é necessário para se certificar que realmente um fluxo de voz começou. Tais fatores adicionais são:

- Tipo de codificador de voz [SCH96];

- SSRC de cada fluxo.

Esses outros fatores são necessários para garantir que somente os pacotes de um fluxo específico, que tenha se iniciado após o estabelecimento da sessão, sejam considerados nas análises relativas a pacotes RTP.

\subsubsection{Interpretação dos pacotes de sinalização}

O processo de interpretação de pacotes caracteriza-se por transformar o payload UDP de um pacote reconhecido SIP, que está em formato texto, em estruturas com formato fixo e conhecido, independentemente do tipo da mensagem.

Essa estrutura, que é gerada depois do processo de interpretação da mensagem, é constituída de acordo com os tipos de campos que podem existir em qualquer mensagem SIP. Dessa forma, a manipulação torna-se mais fácil do que manter a mensagem em formato original de texto, pois qualquer consulta a um campo de cabeçalho específico é feita diretamente dentro da estrutura, no campo correspondente ao da mensagem SIP.

Esse processo de interpretação é feito utilizando a biblioteca oSIP [OSIP], que recebe o texto da mensagem SIP e devolve uma estrutura preenchida com os campos da mensagem e seus valores.

\subsubsection{Análise de transações de forma eficiente em plataformas multicore}

O mecanismo de análise dos pacotes, provenientes de um arquivo aberto do disco ou de uma interface de rede, é a parte mais importante de todo o VolPFix, pois, desse processo, é que se obtém toda a informação a ser apresentada ao usuário analisador.

A forma como esse núcleo de análise foi elaborado permite que o processamento seja indiferente em relação à origem dos pacotes. Porém, quando estes são frutos de um arquivo de disco, utiliza-se de uma técnica que permite aproveitar totalmente os recursos de uma máquina com disponibilidade de processamento paralelo, como é o caso de plataformas multicore.

A tecnologia e os algoritmos utilizados para paralelização da análise dos pacotes será o ponto principal desta subseção, pois é um dos diferenciais que torna o VolPFix uma ferramenta muito eficiente se comparada com outras. Os testes de 
tempo de abertura e processamento de arquivos grandes, descritos na Seção 4.5 Testes de , evidenciam o ganho de desempenho obtido por meio das técnicas inovadoras utilizadas para desempenhar essa tarefa.

A seguir, os pontos principais do mecanismo utilizado são descritos:

a) Tecnologia de processamento paralelo:

Para cumprir um dos objetivos do VolPFix, que é realizar a análise dos pacotes de VoIP de forma ágil, foi necessário utilizar mecanismos de computação paralela em plataformas multicore.

A tarefa mais importante e que consome maior processamento, é a interpretação dos pacotes de sinalização e voz. Ela foi implementada utilizando os próprios mecanismos disponíveis do Qt, chamado de QtConcurrent [SUM10], que é uma API que torna possível escrever programas multi-threaded sem utilizar funções de baixo nível e dependentes do sistema operacional.

b) Algoritmo de interpretação de pacotes de forma paralela:

O QtConcurrent pode trabalhar de diversas maneiras para realizar processamento paralelo. A seguir, a descrição da forma adotada pelo VolPFix para processar os pacotes:

- Tem-se a lista de pacotes montada em ordem de captura;

- passa-se essa lista como argumento para a chamada da função que executa o processamento multi-thread;

- a biblioteca QtConcurrent se encarrega de iniciar tantas threads quanto forem possíveis para tratar essa lista;

- a biblioteca ainda cuida de fazer que cada thread em execução pegue sequencialmente um item da lista, que é um pacote, passando como argumento para a função de interpretação de pacotes.

A

Figura 36 ilustra o algoritmo descrito acima, com um exemplo de processamento paralelo de pacotes, considerando um ambiente com quatro threads: 


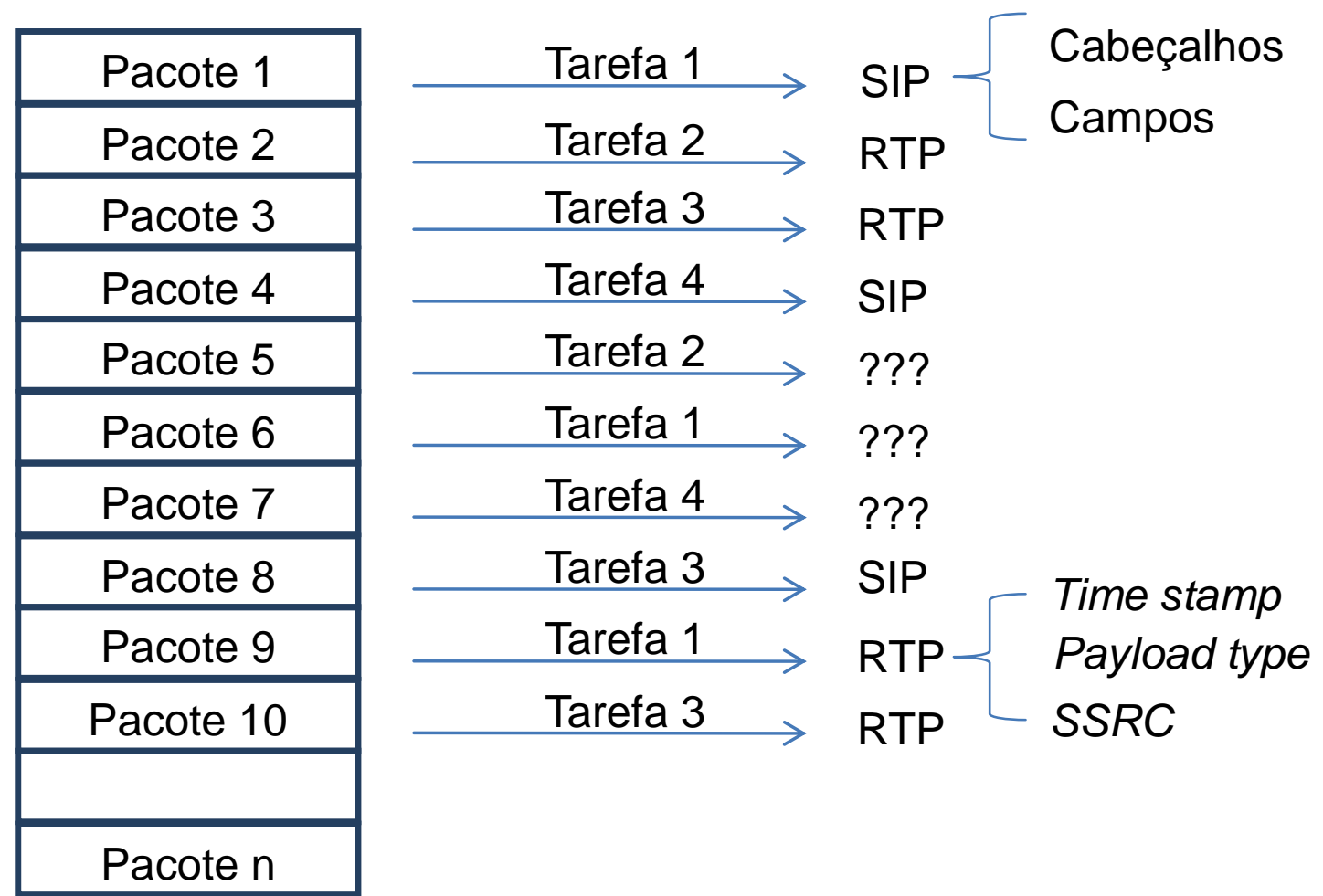

Figura 36 - Interpretação de pacotes em múltiplas tarefas.

Dessa forma os pacotes da lista são tratados pelo interpretador em múltiplas tarefas paralelas, sem necessidade de sincronização, pois, nesse ponto do processo de análise, todos os pacotes são dissociados de transações.

c) Formação das transações:

O VolPFix também utiliza a técnica de processamento paralelo para analisar os pacotes depois da interpretação, agrupando-os em estruturas para formar as transações.

A Figura 37 ilustra um exemplo de análise de pacotes, após o processo de interpretação, considerando um ambiente com quatro threads. Essa situação necessita de sincronização para a escrita de informações na estrutura de cada transação, pois mais de uma tarefa pode analisar um pacote de uma mesma transação. 


\begin{tabular}{|c|}
\hline SIP \\
\hline RTP \\
\hline RTP \\
\hline SIP \\
\hline$? ? ?$ \\
\hline$? ? ?$ \\
\hline$? ? ?$ \\
\hline SIP \\
\hline RTP \\
\hline RTP \\
\hline$\ldots$ \\
\hline SIP \\
\hline
\end{tabular}

\begin{tabular}{ccc}
\hline Tarefa 4 & Transação 1 \\
Tarefa 3 & $\begin{array}{c}\text { Transação 2 } \\
\text { Tarefa 1 }\end{array}$ & $\begin{array}{c}\text { Transação 2 } \\
\text { Tarefa 4 }\end{array}$ \\
\hline Tarefa 2 & Transação 3 \\
\hline Tarefa 2 & \\
\hline Tarefa 3 & \\
\hline Tarefa 1 & \\
\hline Tarefa 4 & Transação 1 \\
\hline Tarefa 2 & Transação 3 & Transação 2
\end{tabular}

Figura 37 - Análise em múltiplas tarefas para formação de transações campos:

A estrutura, que comporta os pacotes de cada transação, possui os seguintes

- call_id: armazena o texto de identificação única, utilizado para encontrar todos pacotes que pertencem à mesma transação;

- tipotrans: variável inteira que guarda o tipo de transação armazenada na estrutura;

- statuscode: corresponde ao código de estado da transação durante o processo de análise da requisição e das respostas. Quando todas as mensagens tiverem sido tratadas, o campo corresponde ao estado de finalização da transação;

- posPacotes: lista de índices que aponta para cada pacote da transação. Ela pode conter pacotes fora da ordem que foram capturados, pois o processo de análise em múltiplas tarefas insere e analisa informações de forma assíncrona, para garantir o máximo de aproveitamento de tempo no processamento;

- numPacotereq: aponta para a lista de índices, indicando o pacote que contém a mensagem de requisição que deu início à transação, pois eles podem estar fora da ordem em que foram capturados;

- ipMediasrc: endereço IP, que o originador de uma chamada ofereceu para receber o fluxo RTP; 
- ipMediaDst: endereço IP, que o receptor de uma chamada ofereceu para receber o fluxo RTP;

- portMediasrc: porta UDP, que o originador de uma chamada ofereceu para receber o fluxo RTP;

- portMediaDst: porta UDP, que o receptor de uma chamada ofereceu para receber o fluxo RTP;

- mediasrcok: flag que indica que pelo menos um pacote do fluxo do originador foi detectado;

- mediaDstok: flag que indica que pelo menos um pacote do fluxo do receptor foi detectado;

- ssrcSrc: inteiro que armazena o número do SSRC do fluxo RTP do originador;

- ssrcDst: inteiro que armazena o número do SSRC do fluxo RTP do receptor;

- lock: objeto que cuida dos mecanismos de sincronização e proteção de escrita e leitura dentro da estrutura de cada transação, durante o processamento paralelo dos pacotes.

A seguir, é apresentado o algoritmo implementado na função de análise das mensagens, para formação das transações, que é executado em processos paralelos em máquinas com múltiplos núcleos:

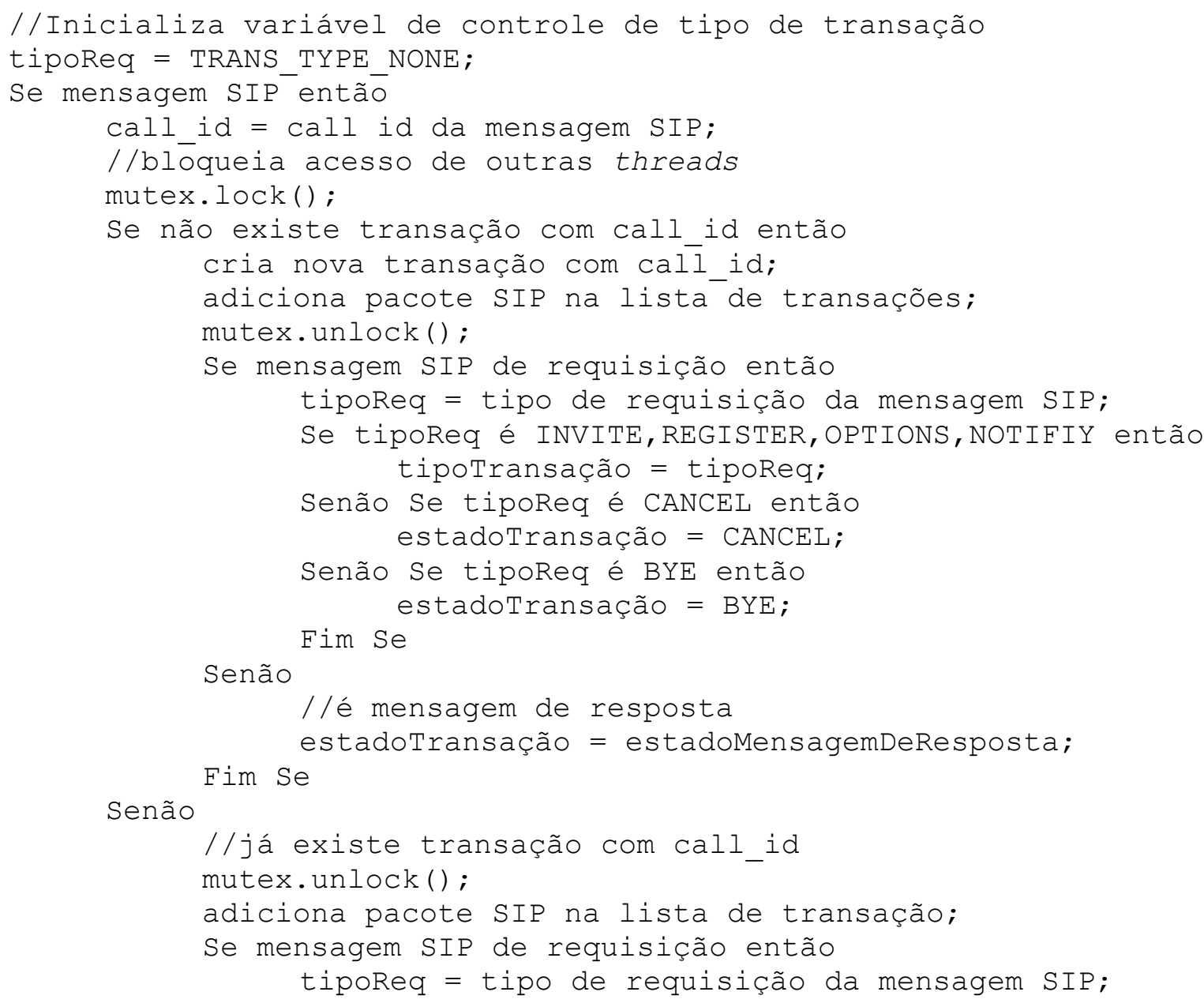




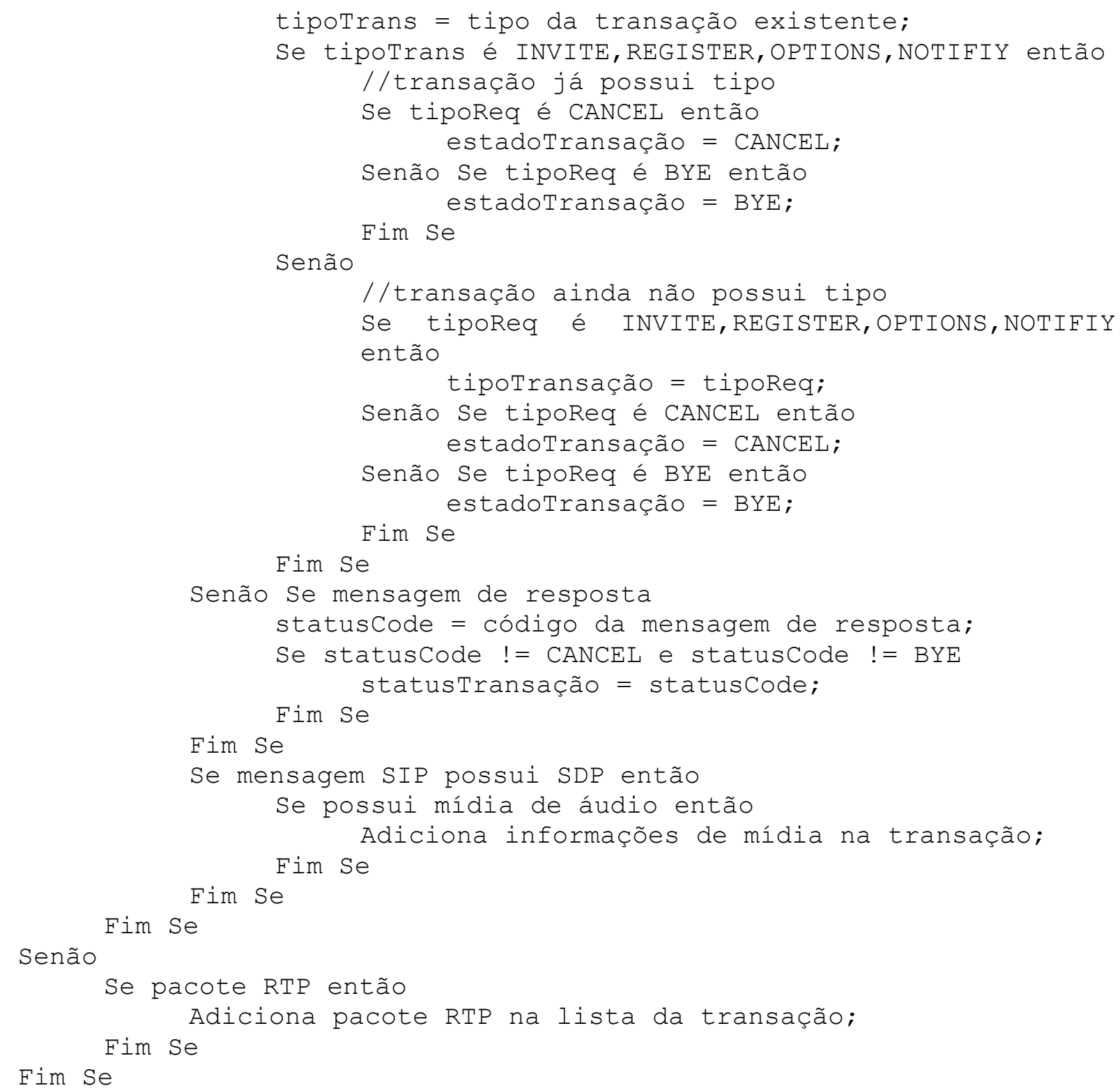

O algoritmo sempre considera que sua execução será feita em um ambiente com processamento paralelo, por isso, em alguns pontos, há o controle de sincronismo, para evitar que mais de uma tarefa escreva dentro da mesma estrutura de uma transação ao mesmo tempo.

Ele ainda possui mecanismos para considerar a análise de mensagens em ordem contrária à sua chegada, pois as tarefas paralelas coletam os itens da lista à medida que concluem a análise do pacote anterior, fazendo com que saiam de sequência, como mostrado na Figura 37.

\subsubsection{Análise durante o processo de captura}

Como foi descrito na Seção 4.4.1, o processo de captura utiliza uma thread para coletar os pacotes que chegam até a interface de rede escolhida, sendo 
enviados diretamente para os mecanismos de interpretação e análise, sem a necessidade de formação de filas.

A análise durante a captura de pacotes utiliza os mesmos mecanismos descritos na Seção 4.4.3. A diferença básica é que os pacotes chegam e são analisados à medida que são capturados, não sendo necessário utilizar processamento paralelo, pois não há formação de filas como acontece quando um arquivo é aberto.

As funções que organizam os pacotes em conjuntos de transações, durante a captura, por meio de uma interface, são as mesmas utilizadas no processamento paralelo, pois foram projetadas para contemplar a situação. Pode-se dizer que o processo é uma particularização desse algoritmo, quando é executado em um processador com um único núcleo, mas com a vantagem de cobrir situações em que os pacotes chegam fora de ordem.

Algumas melhorias serão feitas para que todas as funcionalidades de análise funcionem em conjunto com a captura de pacotes por intermédio de uma interface de rede. Atualmente, não é possível, por exemplo, acompanhar a chegada dos pacotes por gráficos de transações. A Seção 5.1 descreve com mais detalhes os trabalhos futuros nesse sentido.

\subsubsection{Exibição de lista de transações}

A partir da estrutura que agrupa os pacotes de cada transação, formada durante o processo de análise, pode-se exibir uma lista como a da Figura 12.

As informações para montagem dessa tela são retiradas da primeira mensagem, que na maioria dos casos é a de requisição. Somente o campo de estado é coletado da própria estrutura que armazena a transação, pois não depende da análise das demais mensagens.

\subsubsection{Exibição de gráfico detalhado de transações}

Como explicado na Seção 4.2.7, o usuário pode selecionar várias transações para exibir o gráfico detalhado de cada uma. Assim, o VolPFix deve montar uma lista ordenada pelo tempo, contendo todas as mensagens SIP e os pacotes RTP de acordo com a seleção do usuário.

O algoritmo para realização desse trabalho é detalhado abaixo:

- Ordena-se a lista de transações selecionadas pelo usuário de acordo com o tempo de início de cada uma, pois a seleção pode ter sido feita de forma aleatória. Foi utilizado o insertion sort [COR03] para a ordenação crescente, pois é natural que a lista tenha sido gerada pelo usuário já na ordem correta que elas aparecem, e o algoritmo tem um desempenho melhor nessa situação;

- cria-se uma lista principal de pacotes, contendo aqueles necessários a todas as transações selecionadas; 
- ordena-se os pacotes de forma crescente, de acordo com o tempo de cada um, utilizando o algoritmo quick sort [COR03]. Esse passo é necessário, pois as transações podem acontecer num mesmo período de tempo, e as mensagens no gráfico devem aparecer sequencialmente crescentes, independentemente de qual transação ela pertença;

- monta-se a lista de informações para o gráfico, contendo, de cada pacote, o tempo de chegada, endereço IP de origem, porta de origem, endereço IP de destino, porta de destino e o comentário que é exibido acima de cada seta do gráfico. Esse último é retirado da linha de requisição ou código de estado, quando é uma mensagem SIP, ou do tipo do codificador, quando é um pacote RTP. O fluxo unidirecional RTP é representado somente por uma seta, uma vez que seria visualmente desconfortável exibir todos os pacotes;

- monta-se uma lista contendo todos os endereços IP de origem e de destino que aparecem em todos os pacotes, para que o mecanismo que desenha 0 gráfico possa criar as colunas que representam cada endereço. Além disso, ele deve também definir a orientação da seta que representa o pacote.

\subsubsection{Exibição de gráficos com estatísticas}

A janela que mostra as estatísticas exibe gráficos com:

- Número de transações;

- estatísticas de fechamento de chamadas;

- número de chamadas por usuário ou máquina;

- estatísticas de pedidos de registros;

- número de registros por usuário ou máquina.

Todas as informações são retiradas da estrutura gerada durante o processo de análise de pacotes. A contabilidade é feita de acordo com o tipo a ser gerado e exibida em forma de gráfico de barras.

O processo é simples e não utiliza nenhum algoritmo complexo.

\subsubsection{Filtro de transações}

A tela de configuração de filtros, como mostrada na Figura 27, coleta as informações escolhidas pelo usuário e as compara com cada transação da estrutura gerada durante o processo de análise. Depois da comparação, somente as que atenderem às opções escolhidas é que serão exibidas na tela de listagem de transações. de filtros:

A comparação é feita da seguinte forma, de acordo com cada opção da tela

- Tipo de transação: compara a opção escolhida pelo usuário com o método de requisição existente na primeira mensagem SIP da estrutura de transação;

- horário de início: filtra as transações a partir da hora de chegada do primeiro pacote da transação; 
- endereço IP de origem: filtra as transações a partir do endereço IP de origem do primeiro pacote da transação;

- endereço IP de destino: filtra as transações a partir do endereço IP de destino do primeiro pacote da transação;

- usuário de origem: filtra as transações a partir do usuário de origem, presente no campo From da mensagem de requisição;

- usuário de destino: filtra as transações a partir do usuário de origem, presente no campo To da mensagem de requisição;

- estado de finalização da transação: exibe somente as mensagens que possuírem os estados de transação selecionados pelo usuário.

\subsubsection{Medição de jitter, perda de pacotes e erros de sequência}

Os algoritmos utilizados para medição de jitter, perda de pacotes e contabilização de erros de sequência foram implementados segundo os exemplos em linguagem C, propostos no Apêndice A da RFC3550 [SCH03]. Uma descrição mais detalhada pode ser encontrada nesse documento.

O VolPFix alimenta os algoritmos com cada fluxo de áudio retirado da estrutura que armazena os pacotes RTP de cada transação, tendo como saída os valores de:

- Jitter médio e máximo do fluxo;

- quantidade de ocorrências de erros de sequência;

- número de pacotes esperados;

- número de pacotes recebidos.

O percentual de perda de pacotes é calculado a partir do número de pacotes esperados e recebidos.

Basicamente, o algoritmo possui as seguintes características principais:

- Considera um fluxo válido a partir de um número de pacotes detectados;

- permite um número mínimo de pacotes fora de sequência, sem considerar como uma situação de erro;

- possui mecanismos de detecção de reciclagem do número de sequência, sem contabilizar situação de erro.

Foram realizados testes de medição de jitter e perdas de pacotes, comparando os resultados do VolPFix com os do Wireshark, a fim de comprovar a correção da implementação dos algoritmos. Os resultados são apresentados nas Seções 4.5.1 e 4.5.2. 


\subsubsection{Detecção de mudez total ou parcial em chamadas}

O VolPFix detecta mudez total ou parcial em chamadas completadas com qualquer tipo de codificador de voz, pois analisa somente o fluxo de pacotes, sem realizar nenhum tipo de decodificação para extração do áudio.

Da mesma forma como é feita com a medição de jitter, perda de pacotes e erros de sequência, a ferramenta só realiza o processo de detecção de acidentes de fluxo quando o usuário seleciona uma transação na lista e solicita a abertura da janela de relatórios. Essa atitude foi adotada para evitar que o VolPFix execute trabalhos demorados sem necessidade, pois dependendo da quantidade de transações selecionadas e do tempo de cada chamada, o processo pode levar muito tempo para ser realizado.

A mudez total, em um ou em ambos os sentidos do fluxo de áudio, pode ser causada por vários motivos. Abaixo alguns exemplos:

- Erro na negociação dos endereços IP ou porta UDP durante o estabelecimento da chamada;

- falha na ativação dos canais de RTP no equipamento de conversão de mídia;

- problemas de transposição de NAT.

O VolPFix detecta qualquer um desses erros, mas não informa a causa real do problema, pois não há informação suficiente nos traços de captura que esclareçam os fatos com precisão.

O algoritmo, para detecção de mudez total em um dos lados da chamada, utiliza as informações de sessão coletadas no processo de análise e formação das estruturas de transações. Durante a varredura dos pacotes RTP pertencentes à transação em análise, se nenhum for detectado, um flag é marcado, indicando a ocorrência do fato no fluxo correspondente.

Para a detecção de mudez parcial ou ausência momentânea de áudio em um dos fluxos da chamada, o VolPFix utiliza a mesma função para medição de perda de pacotes e erros de sequência. Porém, quando o número de sequência do RTP salta para um valor superior a 100 pacotes, um flag é marcado indicando a ocorrência do acidente do fluxo de áudio. Esse número foi escolhido simplesmente para servir de base de testes para o algoritmo, pois corresponde a dois segundos de ausência em um fluxo em que cada pacote possui $20 \mathrm{~ms}$ de amostra. Em aplicações futuras, 0 usuário poderá configurar o tempo máximo permitido para que a aplicação sinalize a ocorrência do fato.

\subsubsection{Detecção de transações com erros de sinalização}

$\mathrm{Na}$ primeira versão do VolPFix, foram implementados dois testes que verificam e apontam erros de sinalização na finalização de transações de chamada. Apesar de terem sido implementados apenas dois testes, o mecanismo adotado permite que, em trabalhos futuros, outros testes possam ser criados. 
O primeiro caso apresentado na Seção 4.2.16, detectou problema no fechamento da chamada, pois a requisição de BYE não foi entendida pelo receptor da chamada, como pode ser observado com mais detalhes na Figura 38.

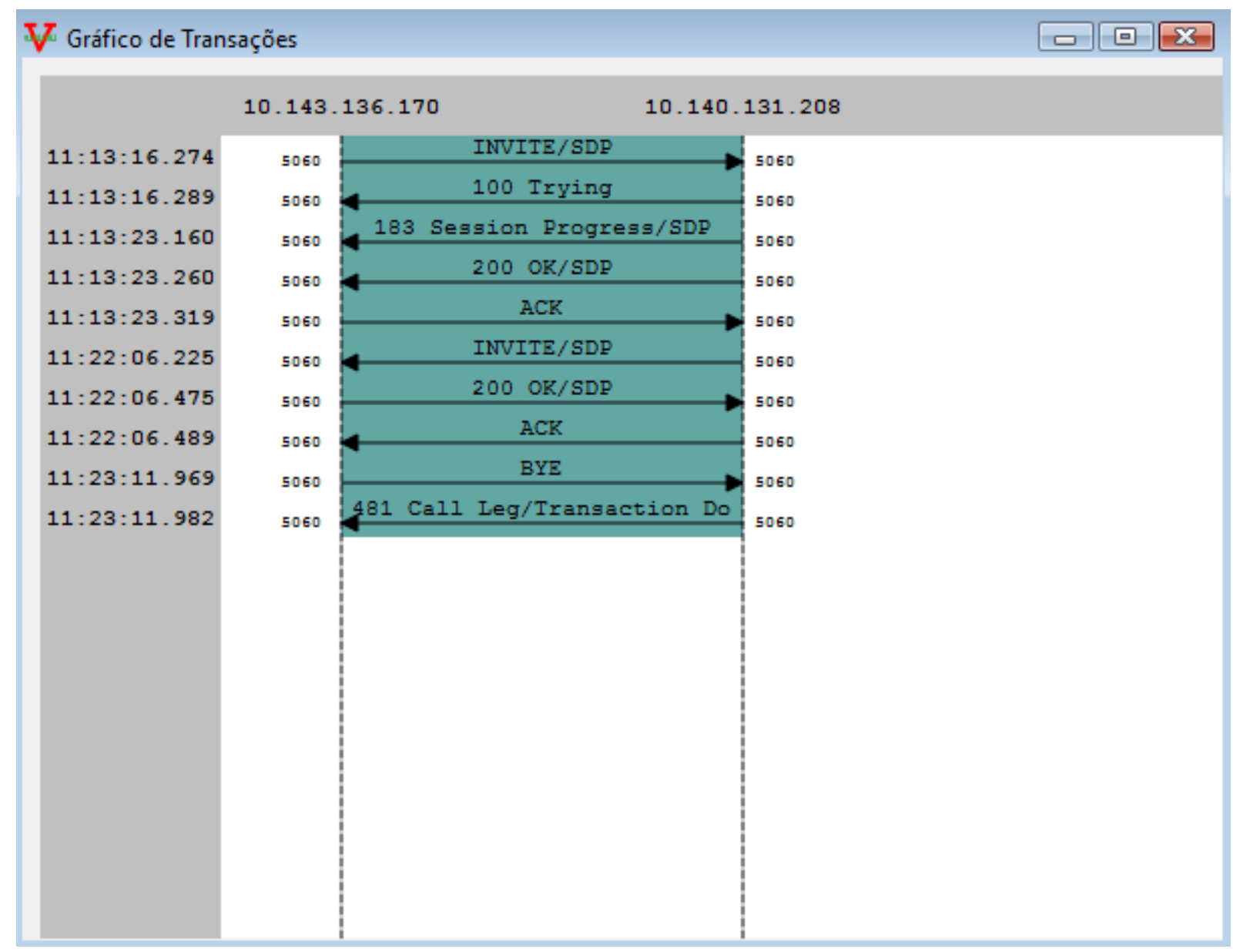

Figura 38 - Gráfico de problema de fechamento de chamada. Caso 1.

A mensagem 481 Call Leg/Transaction Does Not Exist, enviada pelo receptor da chamada em resposta à requisição de BYE, foi detectada pelo VolPFix, caracterizando um problema no desligamento da chamada, uma vez que a resposta correta deveria ser 200 OK. Nesse caso, o VolPFix não foi capaz de identificar claramente o motivo do não reconhecimento da requisição de BYE pelo receptor da chamada.

O algoritmo, para tratar essa situação, procura pelas mensagens de finalização corretas de uma chamada, e, caso não as encontre, sinaliza a existência de um erro grave de sinalização.

O segundo caso apresentado na Seção 4.2.16, mostra uma situação semelhante, como mostra a Figura 39. 


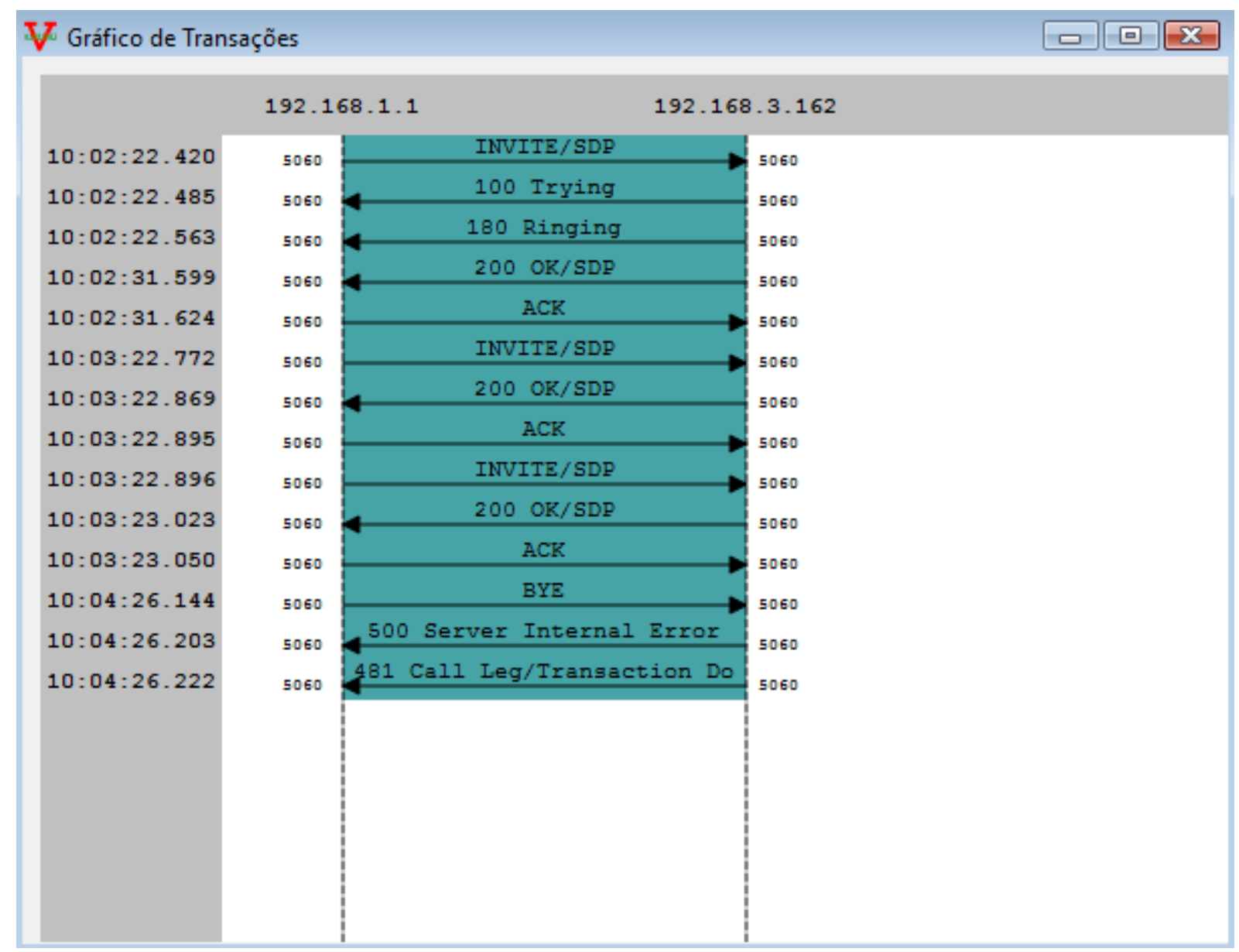

Figura 39 - Gráfico de problema de fechamento de chamada. Caso 2.

O comportamento do receptor da chamada, ao receber a mensagem de BYE, é diferente em relação ao primeiro caso, porém, o VolPFix conseguiu detectar o erro na finalização da chamada, pela ausência de mensagem de resposta 200 OK.

Nesse caso, o algoritmo do VolPFix conseguiu identificar o motivo da recusa da mensagem de BYE, como pode ser observado na Figura 32, no qual a ferramenta cita os valores errados do campo CSeq nessa mensagem.

A especificação de testes da ETSI possui itens específicos para verificação de conformidade, no que diz respeito à finalização de chamadas. O segundo caso apresentado, infringiu a regra descrita no teste SIP_CC_OE_CR_V_004 do documento [MTS07], que diz que uma sessão estabelecida, deve ser finalizada por uma mensagem de BYE com o valor do campo CSeq incrementado de uma unidade. 


\subsubsection{Informativo com causas de problemas com transações}

O campo "estado" da lista de transações não exibe somente a situação de finalização da transação, mas, também, qualquer tipo de erro que acontece durante o fechamento de uma chamada ou pedido de registro.

A obtenção dessa informação é feita durante o processo de análise dos pacotes e da montagem da estrutura que agrupa os pacotes da transação, como já foi explicado na Seção 4.4.3.

\subsubsection{Reprodução do áudio das chamadas com codificador G.711}

O processo para reprodução do áudio de chamadas que foram completadas com o codificador $\mathrm{G} .711$ possui os seguintes passos:

- A partir da transação selecionada pelo usuário para a reprodução, o VolPFix verifica o tipo de codificador utilizado na chamada, restringindo somente as que estiverem codificadas com codificador G.711 lei A ou G.711 lei $\mu$;

- agrupa todos os pacotes RTP do fluxo do originador e receptor em duas listas separadas;

- retira o payload RTP que contém a amostra do áudio codificado de cada pacote;

- faz a conversão utilizando uma tabela para retirar a amostra de áudio;

- gera um arquivo no formato Au [AUF]. A geração desse arquivo é interessante para o processo de reprodução, que pode ser controlado de acordo com o usuário. Além disso, é interessante para trabalhos futuros de exportação do áudio de chamadas;

- exibe a janela da Figura 34, que permite que o usuário controle a reprodução da chamada.

\subsection{Testes de correção}

Foram realizados testes no VoIPFix para avaliar e comparar a precisão das funcionalidades de medição de jitter, perda de pacotes e erros de sequência da aplicação.

A fim de avaliar a correção dos dados apresentados, foi feita a comparação com uma ferramenta muito utilizada, que é o padrão no mundo de open source. Os experimentos mostram que os resultados são tão bons quanto o Wireshark.

\subsubsection{Medição de jitter máximo}

Esse parâmetro indica o maior valor de jitter atingido durante todo o fluxo RTP da chamada. Valores superiores a algumas unidades em relação ao tempo de cada amostra, contida em um pacote, pode fazer com que ele seja descartado, causando picotes no áudio reproduzido. 
Foram selecionados arquivos de captura de casos que continham chamadas com valores de jitter diferentes de zero, para serem analisados pelo VolPFix e pelo Wireshark. Os resultados dos testes são apresentados na Tabela 4.

\begin{tabular}{|l||c|c||c|c||}
\hline \hline Tempo (ms) & \multicolumn{2}{|c|}{ VolPFix } & \multicolumn{2}{c|}{ Wireshark } \\
\hline \hline Fluxo & Originador & Receptor & Originador & Receptor \\
\hline \hline Caso 1 & 0,21 & 25,99 & 0,21 & 26,00 \\
\hline \hline Caso 2 & 0,14 & 11,10 & 0,14 & 11,11 \\
\hline
\end{tabular}

Tabela 4 - Teste de correção: jitter máximo.

Nota-se claramente que, nesses dois casos, os valores encontrados pelas duas ferramentas foram muito próximos, comprovando que a implementação da funcionalidade de medição de jitter do VolPFix foi bem-sucedida.

\subsubsection{Medição de percentual de perda de pacotes}

Foram selecionados arquivos de captura diferentes dos utilizados nos testes de medição de jitter, para análise do percentual de perda de pacotes apontados pelo VolPFix e Wireshark, a fim de realizar comparações. Os resultados são apresentados na Tabela 5.

\begin{tabular}{||l||c|c||c|c||}
\hline & \multicolumn{2}{c|}{ VoIPFix } & \multicolumn{2}{c||}{ Wiresahrk } \\
\hline \hline Fluxo & Originador & Receptor & Originador & Receptor \\
\hline \hline Caso 1 & $0 \%$ & $24,05 \%$ & $0 \%$ & $24,01 \%$ \\
\hline \hline Caso 2 & $4,88 \%$ & $0,30 \%$ & $4,88 \%$ & $0 \%$ \\
\hline
\end{tabular}

Tabela 5 - Teste de correção: perda de pacotes.

Assim como nos testes de medição de jitter, os valores encontrados pelo VolPFix foram muito próximos aos do Wireshark, comprovando também que a implementação do algoritmo de medição de perda de pacotes foi bem-sucedida. A diferença de valores encontrados no fluxo do receptor, deve-se à técnica adotada no VolPFix, segundo a própria recomendação da RFC3550, de somente considerar um fluxo após um número mínimo de pacotes. Como o Wireshark considera um fluxo válido a partir do primeiro pacote, diferenças como essas podem acontecer. 


\subsection{Testes de desempenho com abertura de arquivos grandes}

Os testes de abertura de arquivos grandes foram realizados com o objetivo de avaliar o tempo gasto pelo VolPFix para realizar tal trabalho, comparado com o Wireshark em condições semelhantes.

a) Informações sobre as máquinas utilizadas nos testes

A seguir, uma descrição sobre cada máquina utilizada nos testes:

\begin{tabular}{|c|c|c|c|}
\hline Máquina & Sistema Operacional & Processador & RAM \\
\hline 1 & $\begin{array}{l}\text { Debian } \quad \text { GNU/Linux } \\
\text { kernel } 2.6 .26-2-\text { amd64, } \\
\text { com KDE 3.5.10 64 bits }\end{array}$ & $\begin{array}{l}\text { AMD Phenom II X4 } 945 \quad \text { (4 } \\
\text { núcleos), com clock de } 3 \mathrm{GHz} \text { e } \\
\text { cache de } 512 \mathrm{~KB}\end{array}$ & $4 \mathrm{~GB}$ \\
\hline 2 & $\begin{array}{lr}\text { Debian } & \text { GNU/Linux } \\
\text { kernel } & 2.6 .26-2-686, \\
\text { com KDE } & \text { 3.5.10 } 32 \text { bits }\end{array}$ & $\begin{array}{l}\text { Intel Core } 2 \text { Duo E4600 } \\
\text { núcleos), com clock de } 2.40 \mathrm{GHz} \text { e } \\
\text { cache de } 2048 \mathrm{~KB}\end{array}$ & $2 \mathrm{~GB}$ \\
\hline 3 & $\begin{array}{l}\text { Windows Vista Business } \\
\text { Edition Service Pack } 2 \\
32 \text { bits }\end{array}$ & $\begin{array}{l}\text { Intel Core } 2 \text { Duo E4600 } \\
\text { núcleos), com clock de } 2.40 \mathrm{GHz} \text { e } \\
\text { cache de } 2048 \mathrm{~KB}\end{array}$ & $2 \mathrm{~GB}$ \\
\hline 4 & $\begin{array}{l}\text { Debian } \quad \text { GNU/Linux } \\
\text { kernel 2.6.26-2-amd64, } \\
\text { com Gnome 2.22.3 } 64 \\
\text { bits }\end{array}$ & $\begin{array}{l}\text { Intel Core } 2 \text { Duo T6600 } \\
\text { núcleos), com clock de } 2.20 \mathrm{GHz} \text { e } \\
\text { cache de } 2048 \mathrm{~KB}\end{array}$ & $3 \mathrm{~GB}$ \\
\hline 5 & $\begin{array}{l}\text { Windows } 7 \text { Home Basic } \\
64 \text { bits }\end{array}$ & $\begin{array}{l}\text { Intel Core } 2 \text { Duo T6600 } \\
\text { núcleos), com clock de } 2.20 \mathrm{GHz} \text { e } \\
\text { cache de } 2048 \mathrm{~KB}\end{array}$ & $3 \mathrm{~GB}$ \\
\hline
\end{tabular}

Tabela 6 - Informações sobre máquinas utilizadas nos testes.

b) Informações sobre os arquivos:

Os arquivos utilizados nos testes foram capturados pelo Wireshark em uma rede onde havia alto tráfego de pacotes SIP, RTP e outros. O aplicativo foi 
configurado para gerá-los com tamanho de no máximo 50 MBytes e criar um novo depois de atingir esse limite. A captura foi realizada até a geração de quatro arquivos, que foram mesclados, formando outros de 100, 150 e 200 MBytes.

A seguir, são apresentadas informações relevantes sobre os arquivos utilizados nos teste:

Arquivo de 50 MBytes:

- número de transações SIP: 5869;

- número de transações de registro: 338;

- número de transações de chamada: 62;

- número de pacotes SIP: 23496;

- número de pacotes RTP: 220092;

- $\quad$ número total de pacotes: 388619 .

Arquivo de 100 MBytes:

- número de transações SIP: 7715;

- número de transações de registro: 377;

- número de transações de chamada: 115;

- número de pacotes SIP: 30879;

- número de pacotes RTP: 574781;

- número total de pacotes: 817997.

Arquivo de 150 MBytes:

- $\quad$ número de transações SIP: 8781;

- número de transações de registro: 407

- número de transações de chamada: 154;

- número de pacotes SIP: 35411;

- número de pacotes RTP: 838603;

- número total de pacotes: 1163435.

Arquivo de 200 MBytes:

- número de transações SIP: 11020;

- número de transações de registro: 454;

- número de transações de chamada: 209;

- número de pacotes SIP: 44518;

- número de pacotes RTP: 1224064;

- número total de pacotes: 1629625. 


\subsubsection{Testes}

O procedimento utilizado para avaliar o tempo de abertura de cada arquivo, no Wireshark e no VolPFix, levou em consideração uma das operações que mais é utilizada por um usuário comum de uma ferramenta como essa e, também, uma das que mais consome processamento, que é a abertura da lista de transações, realizada por ambas as aplicações.

No VolPFix, a operação é executada assim que for ordenada a abertura de um arquivo, exibindo todas as transações existentes. No Wireshark, após a escolha do arquivo desejado, é necessário aguardar até que ele exiba todos os pacotes em uma lista, para, depois, acessar o menu que contém a operação que exibe somente as chamadas, pois não há uma funcionalidade que exibe todas as transações, como no VolPFix.

É importante ressaltar que a comparação de desempenho dos dois aplicativos, em relação a essa funcionalidade, considera somente a percepção de tempo do usuário para obter a lista de transações, uma vez que o VolPFix realiza um trabalho maior, analisando e exibindo todas as requisições, não somente as de chamadas, como faz o Wireshark.

A medição de tempo, nos testes com o VolPFix, foi feita com a própria ferramenta, que informa os segundos gastos desde o comando de abertura do arquivo até a exibição de toda a lista de transações. No Wireshark, foi realizada a medição com a ajuda de cronômetro manual, por isso os tempos não são tão precisos quanto no VolPFix.

Foram utilizadas cinco máquinas com arquitetura e sistemas operacionais diferentes durante os testes de abertura de arquivos grandes. $O$ intuito foi de comparar o desempenho de ambas as aplicações, pois utilizam tecnologias bem diferentes, além de salientar o ganho de desempenho do VolPFix em arquitetura com vários núcleos.

A seguir, o resultado dos testes de abertura de cada arquivo, em cada máquina, utilizando o VolPFix e o Wireshark:

a) Arquivo de 50 MBytes:

\begin{tabular}{|l||c||c||c||c|c||}
\hline \hline Tempo (s) & Máquina 1 & Máquina 2 & Máquina 3 & Máquina 4 & Máquina 5 \\
\hline \hline VolPFix & 8,74 & 11,90 & 11,01 & 8,23 & 11,62 \\
\hline \hline Wireshark & 53 & 60 & 47 & 95 & 71 \\
\hline \hline
\end{tabular}

Tabela 7 - Tempo de abertura de arquivo com 50 MB. 
b) Arquivo de 100 MBytes:

\begin{tabular}{|l||c|c|c||c|c|}
\hline Tempo (s) & Máquina 1 & Máquina 2 & Máquina 3 & Máquina 4 & Máquina 5 \\
\hline \hline VolPFix & 23,97 & 31,00 & 25,25 & 21,16 & 28,11 \\
\hline \hline Wireshark & 126 & 160 & 157 & 250 & 175 \\
\hline
\end{tabular}

Tabela 8 - Tempo de abertura de arquivo com 100 MB.

c) Arquivo de 150 MBytes:

\begin{tabular}{||l||c||c|c|c||c||}
\hline Tempo (s) & Máquina 1 & Máquina 2 & Máquina 3 & Máquina 4 & Máquina 5 \\
\hline \hline VolPFix & 46,92 & 60,21 & 43,47 & 39,70 & 49,43 \\
\hline \hline Wireshark & 173 & 230 & 197 & 355 & 240 \\
\hline
\end{tabular}

Tabela 9 - Tempo de abertura de arquivo com 150 MB.

d) Arquivo de 200 MBytes:

\begin{tabular}{||l|c||c|c|c||c|}
\hline Tempo (s) & Máquina 1 & Máquina 2 & Máquina 3 & Máquina 4 & Máquina 5 \\
\hline \hline VolPFix & 64,47 & 90,26 & 62,34 & 58,09 & 72,46 \\
\hline \hline Wireshark & 295 & 390 & 340 & 600 & 460 \\
\hline
\end{tabular}

Tabela 10 - Tempo de abertura de arquivo com 200 MB.

Pelos resultados mostrados acima, é evidente que o VolPFix atingiu com sucesso um dos maiores objetivos propostos, que foi a abertura e a análise de uma grande quantidade de pacotes de forma eficiente, pois ele gastou um tempo bem menor que o Wireshark, principalmente nos arquivos maiores.

A seguir, alguns motivos pelo qual o VolPFix possui uma eficiência superior, se comparada ao Wireshark, em relação ao desempenho de abertura de arquivos:

- Permite processamento paralelo dos pacotes, em máquinas com múltiplos núcleos;

- foi desenvolvido utilizando uma biblioteca para interface gráfica mais avançada, além de técnicas sofisticadas e de alto desempenho;

- utiliza uma biblioteca de interpretação de mensagens SIP muito eficiente, que transforma os textos do protocolo em estruturas de fácil indexação e busca;

- foi construído utilizando algoritmos de ordenação criteriosamente escolhidos para satisfazer as necessidades de cada caso;

- somente realiza processamento de pacotes e mensagens que interessam para a análise de VolP;

- utiliza classes de armazenamento de informações em forma de listas, largamente usado em toda a aplicação, providos pela linguagem de programação Qt, desenvolvidos com foco em desempenho e baixo consumo de memória. 
Para comprovar a eficiência do VolPFix em relação ao Wireshark, foram realizados os mesmos testes de abertura de arquivos grandes, porém em uma máquina com apenas um núcleo. Dessa forma, o VolPFix utilizou apenas uma thread para processar os arquivos e seus pacotes, como o Wireshark. A seguir a descrição da máquina utilizada nos testes:

- Sistema operacional: Kubuntu 8.04 com kernel 2.6.24-16 com KDE versão 3.5.9;

- processador: AMD Athlon XP 2400+, com clock de $2 \mathrm{GHz}$ - single core;

- memória RAM: 512 MB.

Os resultados são apresentados na Tabela 11.

\begin{tabular}{|l|c|c|c|c||}
\hline $\begin{array}{l}\text { Tamanho do arquivo / } \\
\text { Tempo (s) }\end{array}$ & 50 MB & 100 MB & $\mathbf{1 5 0}$ MB & $\mathbf{2 0 0}$ MB \\
\hline \hline VolPFix & 29,50 & 97,30 & 205,05 & 322,11 \\
\hline \hline Wireshark & 274 & 790 & 1210 & 2180 \\
\hline
\end{tabular}

Tabela 11 - Teste de desempenho em máquina de um núcleo.

\subsection{Comparação com outras ferramentas}

A Tabela 12 mostra um comparativo realizado entre o VolPFix, o Wireshark e - Cace Pilot, a respeito das principais funcionalidades de análise de pacotes de VolP das três aplicações: 


\begin{tabular}{|c|c|c|c|}
\hline Funcionalidade & VolPFix & Wireshark & Cace Pilot \\
\hline Captura de pacotes & $\sqrt{ }$ & $\sqrt{ }$ & $\sqrt{ }$ \\
\hline $\begin{array}{l}\text { Análise de forma ágil em plataformas } \\
\text { multicore }\end{array}$ & $\sqrt{ }$ & & $\sqrt{ }$ \\
\hline Exibição de detalhes das mensagens & $\sqrt{ }$ & $\sqrt{ }$ & \\
\hline Operação em sistema GNU/Linux & $\sqrt{ }$ & $\sqrt{ }$ & \\
\hline Exibição de lista de transações de registro & $\sqrt{ }$ & & \\
\hline Exibição de lista de transações de chamada & $\sqrt{ }$ & $\sqrt{ }$ & $\sqrt{ }$ \\
\hline Gráfico detalhado das transações de registro & $\sqrt{ }$ & & \\
\hline $\begin{array}{l}\text { Gráfico detalhado das transações de } \\
\text { chamadas }\end{array}$ & $\sqrt{ }$ & $\sqrt{ }$ & \\
\hline $\begin{array}{l}\text { Detecção de mudez total ou parcial em } \\
\text { chamadas }\end{array}$ & $\sqrt{ }$ & & \\
\hline Detecção de erros de sinalização & $\sqrt{ }$ & & \\
\hline $\begin{array}{l}\text { Localização de transações com base no } \\
\text { usuário ou endereço da máquina }\end{array}$ & $\sqrt{ }$ & & \\
\hline Análise durante o processo de captura & $\sqrt{ }$ & $\sqrt{ }$ & $\sqrt{ }$ \\
\hline Análise de arquivos gravados em sequência & $\sqrt{ }$ & & \\
\hline Gráfico com estatísticas de chamadas & $\sqrt{ }$ & & $\sqrt{ }$ \\
\hline $\begin{array}{l}\text { Reprodução das chamadas com codificador } \\
\text { G711 }\end{array}$ & $\sqrt{ }$ & $\sqrt{ }$ & \\
\hline $\begin{array}{l}\text { Medição de jitter, perda de pacotes e erros de } \\
\text { sequência }\end{array}$ & $\sqrt{ }$ & $\sqrt{ }$ & $\sqrt{ }$ \\
\hline Informativo de problemas de transações & $\sqrt{ }$ & & \\
\hline $\begin{array}{l}\text { Exibição de gráfico com estatísticas de } \\
\text { número de transações de chamada por } \\
\text { usuário ou máquina }\end{array}$ & $\sqrt{ }$ & & $\sqrt{ }$ \\
\hline $\begin{array}{l}\text { Exibição de gráfico com estatísticas de } \\
\text { número de transações de registro por usuário } \\
\text { ou máquina }\end{array}$ & $\sqrt{ }$ & & \\
\hline
\end{tabular}

Tabela 12 - Comparativo de funcionalidades com Wireshark e Cace Pilot.

É importante ressaltar alguns diferenciais do VolPFix em relação ao Wireshark e o Cace Pilot. A seguir, um detalhamento dessas vantagens. 


\subsubsection{Análise de forma eficiente em plataformas multicore}

O ganho de desempenho do VolPFix, em relação ao Wireshark, para realização de tarefas que demandam grande poder de processamento, ficou evidente nos testes apresentados na Seção 4.6. Não somente para abertura de arquivos grandes, mas, também, para geração de relatórios e medições de jitter, que necessita de análise de todos os pacotes do fluxo de mídia.

A arquitetura implementada no VolPFix permitirá novas implementações e evoluções, que poderão aproveitar a base já desenvolvida para processamento paralelo, tornando-o eficiente em outras funcionalidades.

\subsubsection{Exibição de transações de registro}

Exibir as transações de registro em listas e em forma de gráficos é de extrema utilidade durante o processo de análise de um sistema de telefonia IP. Essa funcionalidade não foi implementada no Wireshark nem no Cace Pilot, porém, no VolPFix, teve o tratamento de importância igual às transações de chamada.

Várias situações exigem investigação das transações de registro. O VolPFix fornece boas ferramentas para facilitar a operação e o trabalho do usuário analisador nesses casos.

\subsubsection{Detecção de mudez total ou parcial em chamadas}

Com essa funcionalidade, o usuário do VolPFix poderá ser alertado de situações de mudez em transações de chamada. A facilidade de diagnósticos em situações assim traz grandes benefícios para o usuário analisador, que não mais necessita investigar o fluxo de mídia pacote a pacote até encontrar algum tipo de problema que explique o caso.

O Wireshark e o Cace Pilot possuem funcionalidades que expressam perda de pacotes, mas não alertam sobre a ausência de um fluxo total ou parcial, como é feito no VolPFix.

\subsubsection{Detecção de erros de sinalização}

Uma das grandes funcionalidade do VolPFix, para usuários que não possuem conhecimento profundo nos protocolos envolvidos, é a detecção de erros de sinalização.

Poucos casos foram implementados na atual versão da ferramenta, porém a base de interpretação está pronta para ser expandida e cobrir todos os casos previstos no documento de testes da ETSI [MTS07]. 


\subsubsection{Medição de jitter, perda de pacotes e erros de sequência}

A forma como o Wireshark disponibiliza essas funcionalidades torna-o pouco eficiente, pois a análise é dissociada da transação da chamada, fazendo que o usuário analisador tenha de realizar os seguintes passos:

- Tendo um arquivo aberto ou pacotes capturados através de uma interface de rede, selecionar a opção que exibe as transações de chamadas;

- exibir o gráfico da transação desejada;

- clicar sobre o pacote RTP do fluxo desejado para ser analisado;

- acessar o menu de análise de fluxo RTP, que é um processo separado da análise das transações. Essa atitude leva muito tempo para ser executada, quando é feita em arquivos muito grandes.

No VolPFix, a análise desses parâmetros está diretamente associada à transação de chamada. O usuário analisador deve apenas selecionar a transação desejada e, a partir daí, comandar a abertura do relatório que contém as informações buscadas. 


\section{Conclusão}

O VolPFix foi construído para atender as necessidades de uma ferramenta de análise para o mundo de telefonia IP, de modo eficiente e de fácil operação por usuários com um mínimo de conhecimento da área.

Seus objetivos foram alcançados, apesar das limitações em algumas ferramentas, principalmente em situações de captura em tempo real de pacotes. Porém, a base desenvolvida permitirá evoluções e melhorias, permitindo acompanhar a evolução dos sistemas computacionais em relação a processamento de alto desempenho.

O VolPFix já é utilizado como ferramenta, pelo próprio autor desta dissertação, que trabalha na empresa Leucotron Telecom, desenvolvendo equipamentos de comunicação privada (centrais PBX) e soluções de telefonia IP, substituindo o Wireshark em todas as situações como:

- Detecção de eventos anormais no sistema de telefonia principal da empresa;

- análise de problemas em campo;

- verificação de funcionamento de equipamentos de testes em laboratório;

- medição de jitter e perda de pacotes em ensaios de grande escala.

Seu desempenho, estabilidade e facilidade de operação ajudarão muitos profissionais que dependem de boas ferramentas gratuitas para auxiliar no trabalho de análise de pacotes de rede no mundo de telefonia IP.

O VolPFix está disponibilizado como um projeto de software livre através do Centro de Competência de Software Livre do IME-USP, no sítio http://ccsl.ime.usp.br/voipfix, sob a licença GNU General Public License v.3.

\subsection{Trabalhos futuros}

A base desenvolvida neste trabalho permitirá evoluções, melhorias e criações de novas funcionalidades para o VolPFix. Algumas delas são descritas a seguir.

a) Medição de qualidade de voz:

Implementação de medição de qualidade de voz, segundo o Modelo $E$, detalhado no trabalho [CAR04], a partir do jitter e perda de pacotes, valores já calculados pelo VolPFix em uma chamada.

As alterações na estrutura do VolPFix serão pontuais, devendo influenciar especificamente nas funções de análise de fluxo RTP.

b) Reprodução de áudio de chamadas com iLBC:

Reproduzir áudio de chamadas apenas com o codificador G.711 não é satisfatório para muitas situações, porém o VolPFix foi preparado para incorporação 
de outros codificadores de voz, como o iLBC, que não necessita de pagamento de royalties para ser utilizado.

c) Outras análises durante a captura:

A análise do VolPFix durante o processo de captura restringe-se à exibição somente da lista de transações. A proposta é melhorar os mecanismos, permitindo a realização de todas as tarefas, sem que o usuário tenha de interromper a captura ou mesmo fechar algumas janelas e reabri-las novamente, como é feito com o Wireshark.

d) Exportação de logs de eventos:

Um dos projetos futuros, é fazer que o VolPFix torne-se uma ferramenta de gerência proativa de sistemas de telefonia IP, exportando os logs de eventos para um computador remoto, durante o processo de captura, por meio de SysLog ou outro protocolo. Dessa forma, o administrador de redes poderá ser informado de eventos como:

- erros de sinalização em transações de chamada ou registro

- presença de equipamentos com comportamento incorreto na rede;

- queda de qualidade de voz ou aumento de fatores como jitter e perda de pacotes;

- ataques de scanners SIP;

- dificuldade de registro ou estabelecimento de chamada por algum usuário.

e) Detecção de dígitos no payload RTP:

O VolPFix detecta 0 transporte de dígitos DTMF somente através de mensagens do tipo SIP INFO. Em versões futuras, será implementada a detecção dos dígitos que estiverem presentes no payload RTP do fluxo de áudio [SCH00].

\section{f) Gráfico de jitter e taxa de perda de pacotes ao longo da chamada:}

Os valores de jitter e perda de pacotes, medidos pelo VolPFix no final de uma chamada, são importantes para uma primeira avaliação da qualidade da chamada e do meio de transmissão.

Como trabalho futuro, serão feitos gráficos para exibição da evolução desses parâmetros durante a chamada, permitindo ao usuário a inspeção dos momentos críticos no exato ponto onde ocorreram.

O VolPFix continuará a ser desenvolvido pelo autor, agregando novas funcionalidades, tornando-o cada vez mais eficiente. Será feito um esforço para 
atrair a comunidade de usuários e desenvolvedores interessada nesse tipo de ferramenta, para aprimorá-lo e contribuir para a criação de melhorias. 


\section{Bibliografia}

[AGR08]. AGRAWAL, A. et al. SIP/RTP Session Analysis and Tracking for VoIP Logging. In $16^{\text {th }}$ IEEE International Conference, páginas 1-5. 2008.

[AND04]. ANDERSEN, S. et al. Internet Low Bit Rate Codec (iLBC). 2004. IETF RFC3951.

[ANA10]. Requisitos Técnicos e Procedimentos de Ensaios Aplicáveis à Certificação de Produtos para Telecomunicação de Categoria 1. Agência Nacional de Telecomunicações. Brasil. 2010.

[AST]. ASTERISK: The Open Source Telephony Project. http://www.asterisk.org. Último acesso em 14/11/2010.

[AUF]. Au File Format.

http://www.opengroup.org/public/pubs/external/auformat.html. Último acesso em 03/10/2010.

[BAO09]. BAO, D. et al. Session Initiation Protocol Automatic Debugger. In IEEE Transactions on Instrumentation and Measurement, volume 58, número 6. June 2009.

[BLA08]. BLANCHETTE, J.; SUMMERFIELD, M. C++ GUI Programming with Qt 4. 2nd. ed. Prentice Hall. 2008. 752 p.

[BS06]. BASET, Salman A., SCHULZRINNE, H. An Analysis of the Skype Peerto-Peer Internet Telephony Protocol. In $25^{\text {th }}$ IEEE International Conference on Computer Communications, páginas 1-11. 2006.

[CACE]. CACE Pilot. http://www.cacetech.com. Último acesso em 07/11/2010.

[CAM02]. CAMPBELL, B., et al. The SIP Extension for Instant Messaging. 2002. IETF RFC3428.

[CAR04]. CARVALHO, L. S. G. D. Implementação do Modelo E para Avaliação Objetiva da Qualidade de Fala em Redes de Comunicação VolP. 2004. 169 p. Dissertação (Mestrado em Ciência da Computação) - Instituto de Ciências Exatas, Universidade Federal do Amazonas, Manaus, Setembro de 2004.

[CHAT]. TELEFONE IP Chatty. http://www.leucotron.com.br/aparelhotelefonico/chattyip. Último acesso em 15/11/2010.

[COR03]. CORMEN, Thomas H., et al. Introduction to Algorithms. 2nd. ed. McGraw-Hill. 2003. 1056 p.

[CUE00]. CUERVO, F., et al. Megaco Protocol Version 1.0. 2000. IETF RFC3015.

[DON00]. DONOVAN, S. The SIP INFO Method. 2000. IETF RFC2976. 
[EGE94]. Egevang, K. et al. The IP Network Address Translator (NAT). 1994. IETF RFC1631.

[FIE99]. FIELDING, R. et al. Hypertext Transfer Protocol - HTTP/1.1. 1999. IETF RFC2616.

[HAN98]. HANDLEY, M.; JACOBSON, V. SDP: Session Description Protocol. 1998. IETF RFC2327.

[IETF]. IETF. http://www.ietf.org. Último acesso em 10/11/2010.

[ISI]. ISION IP: PBX IP. http://www.leucotron.com.br/pabx/ision-ip/conheca. Último acesso em 15/11/2010.

[ITU07]. Recommendation ITU-T G.729. Coding of speech at $8 \mathrm{kbit} / \mathrm{s}$ using conjugate-structure algebraic-code-excited linear prediction (CS-ACELP). 2007.

[ITU09]. Recommendation ITU-T H.323, version 7.0. Infrastructure of audiovisual services - Systems and terminal equipment for audiovisual services. 2009.

[ITU72]. Recommendation ITU-T G.711. Pulse Code Modulation (PCM) of Voice Frequencies. 1972.

[JOH03]. JOHNSTON, A. et al. SIP Basic Call Flow Examples. 2003. IETF RFC3665.

[JOH04]. JOHNSTON, ALAN B. Undestanding the Session Initiation Protocol. 2nd. ed. Artech House Telecommunications. 2004. 283 p.

[KP09]. KARAPANTAZIS, S., PAVLIDOU, F. VoIP: A comprehensive survey on a promising technology. In The International Journal of Computer and Telecommunications Networking, volume 53, issue 12, agosto de 2009.

[MTS07]. Methods for Testing and Specification (MTS); Conformance Test Specification for SIP (IETF RFC3261); Part 2: Test Suite Structure and Test Purposes (TSS\&TP). 2007. (ETSI TS 102 027-2 V4.1.1).

[OSIP]. OSIP. http://www.gnu.org/software/osip. Último acesso em 01/05/2010.

[PCAP]. PCAP Next Generation Dump File Format. http://www.winpcap.org/ntar/draft/PCAP-DumpFileFormat.html. Último acesso em 02/10/2010.

[PER03]. PERKINS, C. RTP Audio and Video for the Internet. Addison-Wesley Professional. 2003. 432 p.

[POS80a]. POSTEL, J. User Datagram Protocol. 1980. IETF RFC768.

[POS80b]. POSTEL, J. Transmission Control Protocol. 1980. IETF RFC761. 
[QT]. QT - Cross-platform application and UI framework. http://qt.nokia.com. Último acesso em 13/11/2010.

[ROA03]. ROACH, A. SIP Specific Event Notification. 2003. IETF RFC3265.

[ROS02a]. ROSENBERG, J. et al. SIP: Session Initiation Protocol. 2002. IETF RFC3261.

[ROS02b]. ROSENBERG, J. The SIP UPDATE Method. 2002. IETF RFC3311.

[RS02a]. ROSENBERG, J. and SCHULZRINNE, H. Reliability of Provisional Responses in SIP. 2002. IETF RFC3262.

[RS02b]. ROSENBERG, J. and SCHULZRINNE, H. An Offer/Answer Model with the SDP. 2002. IETF RFC3264.

[SCH00]. SCHULZRINNE, H. et al. RTP Payload for DTMF Digits, Telephony Tones and Telephony Signals. 2003. IETF RFC2833.

[SCH03]. SCHULZRINNE, H. et al. RTP: A Transport Protocol for Real-Time Applications. 2003. IETF RFC3550.

[SCH96]. SCHULZRINNE, H. et al. RTP Profile for Audio and Video Conferences with Minimal Control. 1996. IETF RFC1890.

[SPA03]. SPARKS, R. The SIP Refer Method. 2003. IETF RFC3515.

[SUM10]. SUMMERFIELD, M. Advanced Qt Programming. Prentice Hall. 2010. 536 p.

[TCPD]. TCPDUMP/LIBPCAP . http://www.tcpdump.org. Último acesso em 02/10/2010.

[TELE]. ESTATÍSTICAS de VoIP. Teleco, http://www.teleco.com.br/voip_estatis.asp. Último acesso em 14/11/2010

[TRIX]. TRIXBOX: The Open Platform for Business Telephony. http://www.trixbox.org. Último acesso em 02/05/2010.

[VOIP] VoIPFix. http://ccsl.ime.usp.br/voipfix. Último acesso em 03/01/2011.

[XLT]. X-LITE. http://www.counterpath.com/x-lite.html. Último acesso em 01/05/2010.

[YER98]. YERGEAU, F. UTF-8, A transformation format of ISO 10646. 1998. IETF RFC2279.

[WINP]. WINPCAP. http://www.winpcap.org. Último acesso em 02/10/2010.

[WIRa]. WIRESHARK . www.wireshark.org. Último acesso em 01/11/2010. 
[WIRb]. WIRESHARK Performance. http://wiki.wireshark.org/Performance. Último acesso em 14/11/2010. 